
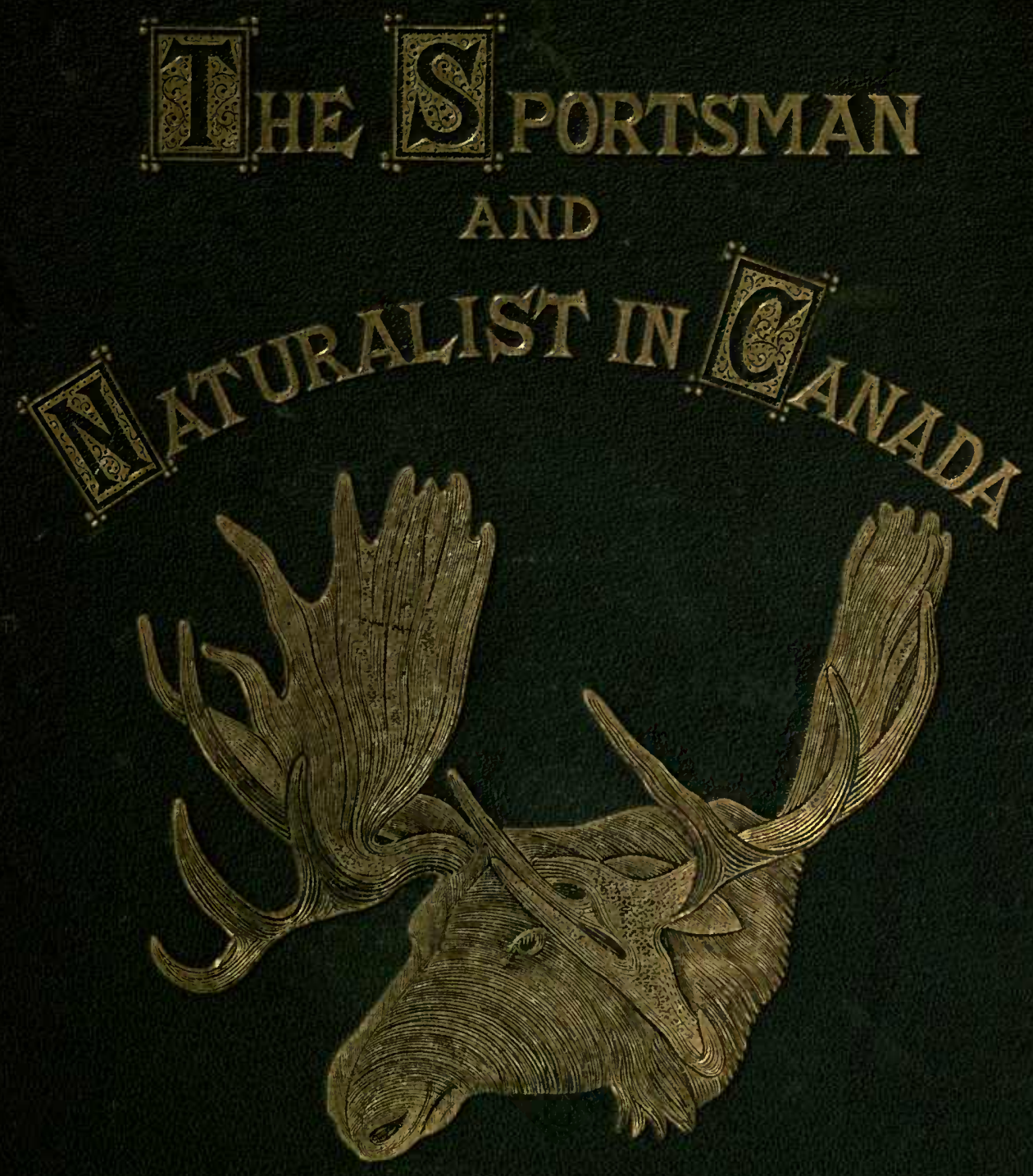

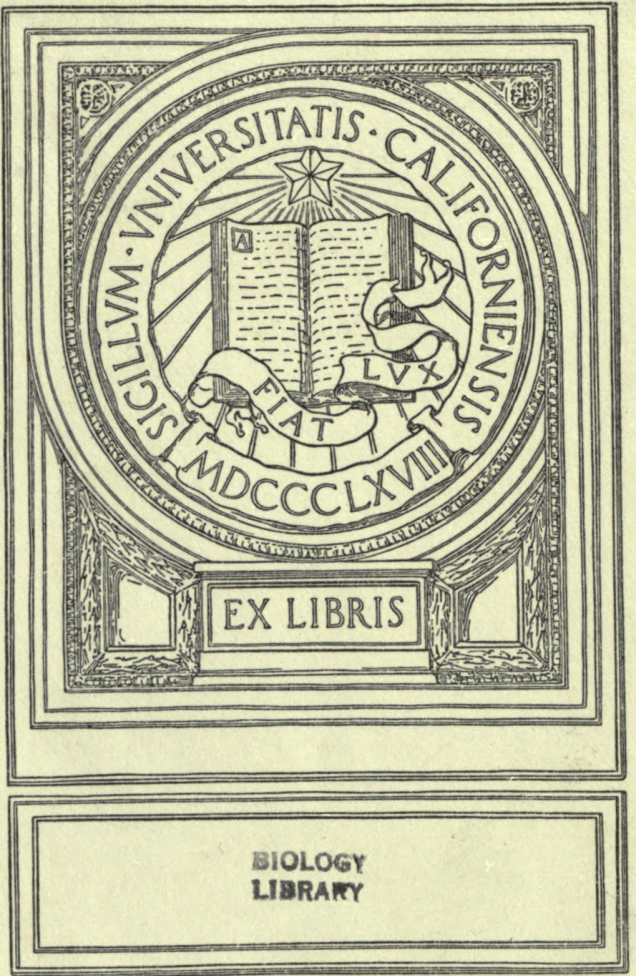




\section{THE SPORTSMAN}

AND

NATURALIST IN CANADA. 




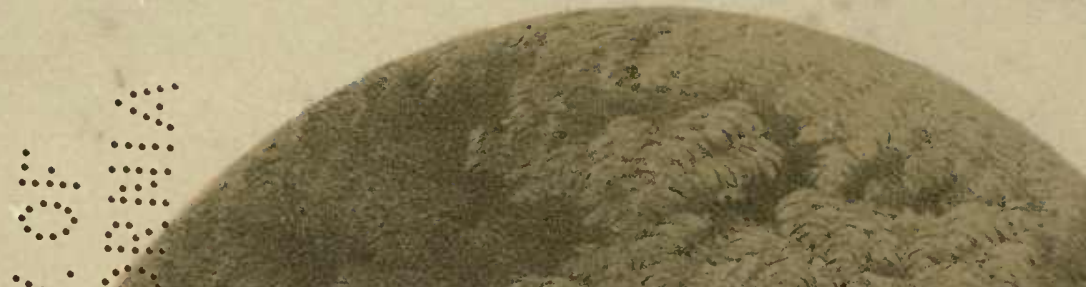

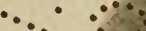

$\because \cdots:$

..... …

$\therefore: \therefore$

... …

....

$\because \because \cdots$

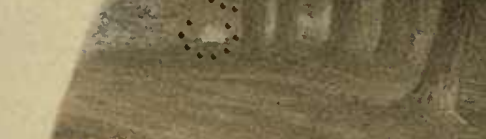

$x^{2}+, n+2$

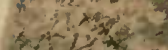

$x^{2} y^{3}+2=3$

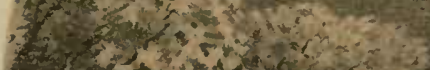

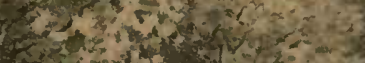

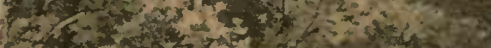

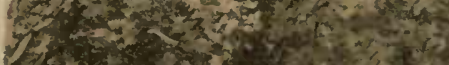

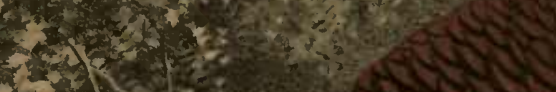

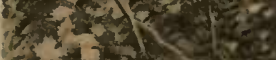

$(1+x)$

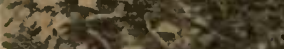

$2,2=0$

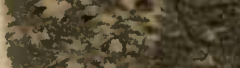

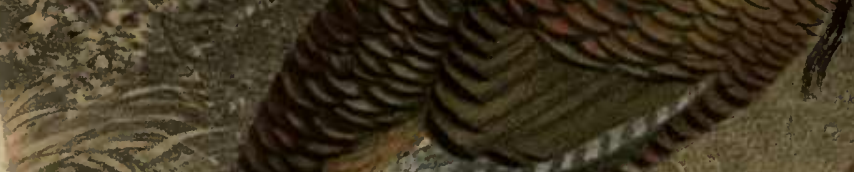
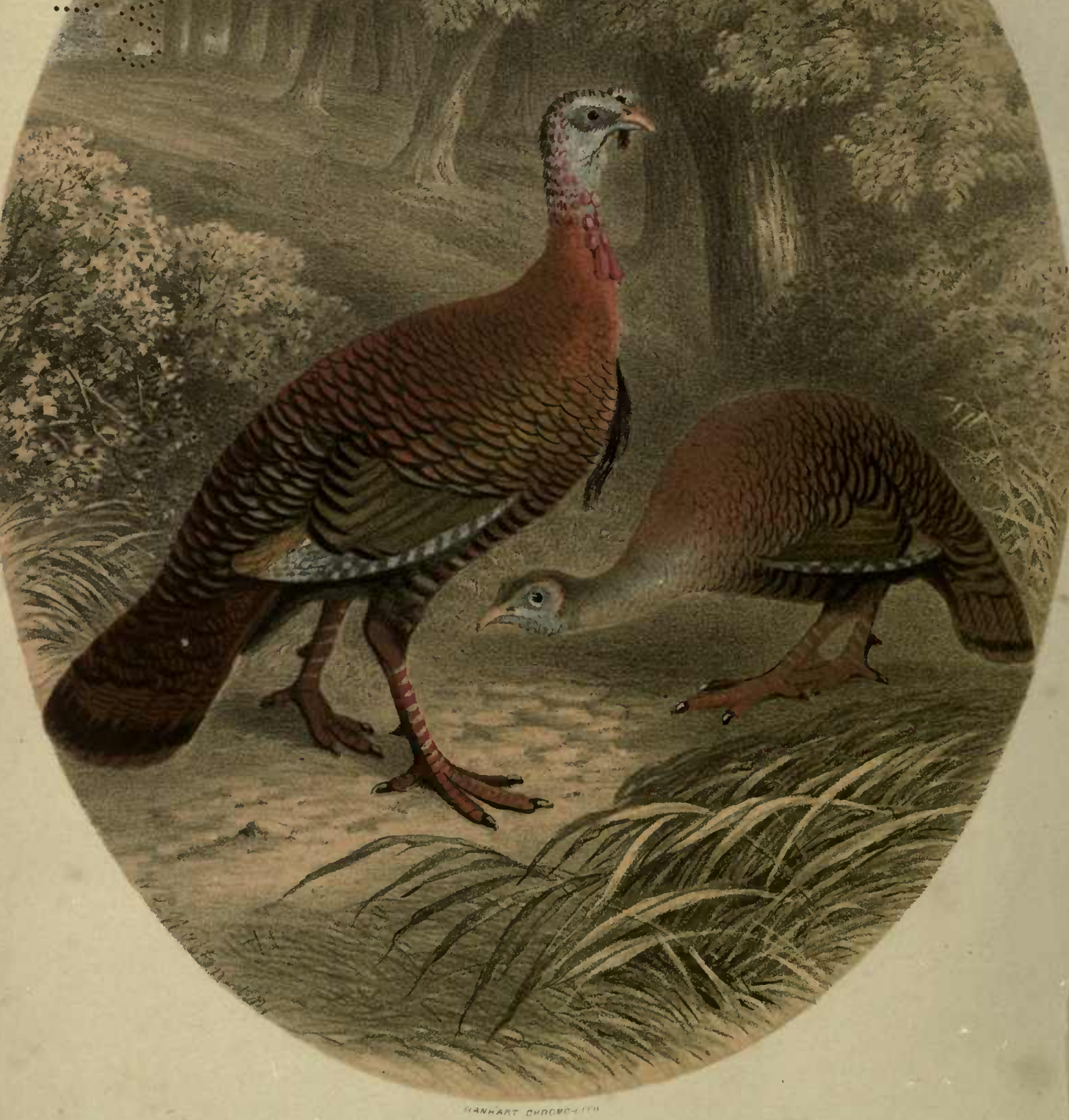

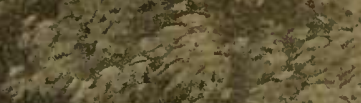

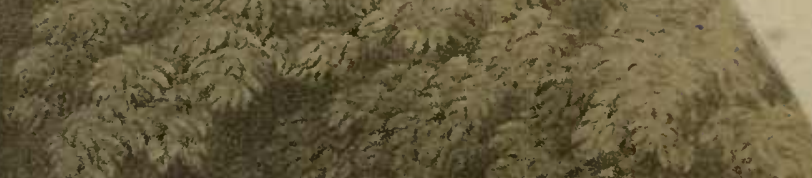

s

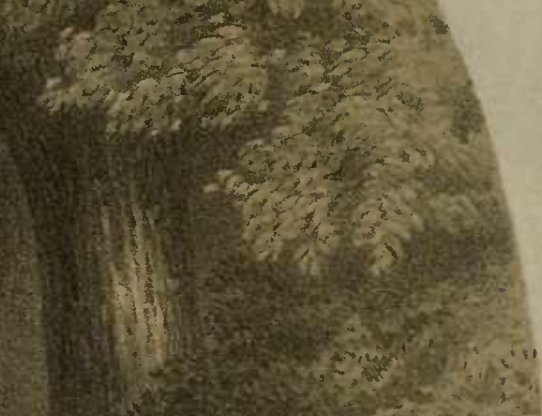

2.

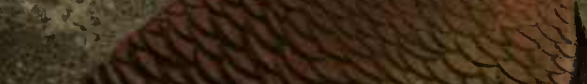

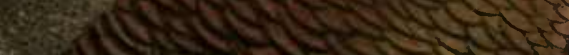

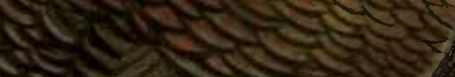

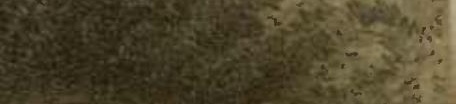

(3) 




\title{
THE SPORTSMAN
}

AND

\section{NATURALIST IN CANADA,}

\author{
(1) $x$ 党lotes
}

on

THE NATURAL HISTORY OF THE GAME, GAME BIRDS, AND FISH OF THAT COUNTRY.

MAJOR W. ROSS $\underset{11}{\text { Knattached. }}$ KING,

F.R.G.S., F.S.A.S.

AUTHOR OF

"CAMPAIGNING IN KAFFIRLAND."

ILLUSTRATED WITH COLOURED PLATES AND WOODCUTS.

\section{LONDON :}

HURST AND BLACKETT, PUBLISHERS, 13, GREAT MARLBOROUGH STREET.

1866.

The right of Translation is reserved. 


$$
\because \vdots \because \vdots \vdots \vdots \vdots \vdots \vdots \vdots \vdots \vdots \vdots \vdots \vdots \vdots \vdots
$$

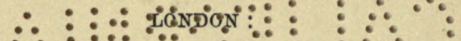

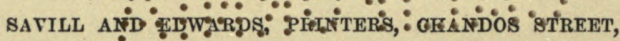 \\ COVENT GARDEN.
}




\section{PRE F A CE.}

Few scenes so easily reached from our own shores better repay a visit than the forests, lakes, and rivers of British North America.

Whether to the sportsman, the naturalist, or the traveller, nothing can well be more alluring than its vast tracts of primæval forest, inhabited by moose and caribou; its game-stocked prairies of boundless extent; and its broad rivers, filled with silvery salmon and spotted trout; flowing through grand and picturesque solitudes, little known and less frequented.

Taking the St. Lawrence route, the traveller from our own country is landed at Quebec in about ten or eleven days. He may revel among the salmon rivers below that city; strike up-country in pursuit of large game; make a pilgrimage to the Falls of Niagara; float over the great Lakes; fill his sketch-book with the glorious views that everywhere attract the artist; may kill his grouse on the broad prairies; and be back again before winter, relating his adventures by his own fireside. 
The climate is as healthy as it is delightful, at all seasons: whether in the glorious days of summer, when ruby-throated humming-birds flit from flower to flower; in the glowing autumn, when tints of brightness unknown in other lands invest the forest with their gorgeous mantle; in the dreamy softness of that wonderful period called the "Indian summer;" or in the clear glistening winter, with its sparkling fields of pure snow, its cloudless blue skies, and merry sleigh-bells.

During a sojourn in these regions, extending over a period of three years, constantly rod in hand or roaming the woods with dog and gun, I habitually recorded in my note-book memoranda on the haunts and habits of the birds and animals which I have endeavoured to describe in the succeeding pages; and I can only hope that my jottings may be useful to those who read them, with the view of themselves enjoying the same pursuits, and interesting to those who would recal similar bygone days of agreeable recreation.

In the following chapters I have, as far as regards the Mammals and Birds, adopted the nomenclature of Baird, (the most recent writer on the Natural History of his own country,) and in the remaining division of the work I am personally indebted to Mr. Nettle, the Government Superintendent of the Fisheries of Lower Canada, for details of statistical information not generally accessible, 
and on which his official position enables him to speak with weight and authority.

Our great works on Natural History, while too bulky for the traveller, are only within reach of the few; separate accounts relating to special localities, when based on personal and accurate observation, are therefore always of value. I have accordingly attempted to give an account of the game, and fresh-water fish, of the Canadas, with notices of their habitats, which, while possessing some scientific arrangement, shall be sufficiently free from unintelligible terms to make the work available for the use of those who have no taste for the systematic study of Natural History.

Tertowie, May, 1866. 


\section{GENERAL CONTENTS.}

\section{CHAPTER I.}

Decrease of Carnivores-The Black Bear-Its Present Haunts-Head Waters of the Ottawa-Distinct from Black Bear of EuropePeriod of Hibernation-Its Duration-Female Bear-Cubs-Hunting-Fur of the Bear-Indian Superstition-Migration in Search of Food-Bear Killed at Niagara-The Wolf-Districts which it inhabits-Compared with European Wolf-Habits and CunningWolf-Hunting-Varieties of Foxes-The Red Fox-Different from European One-The Cross Fox-The Silver Fox-Trade in Fox Skins-Great Value of Silver Fox Skin-The Lynx-Its Inoffensiveness-Variety in Colour of Fur-Flesh eaten by IndiansPower of Swimming-Food-The Wolverine-The Puma-Its Scarcity-Skunks in Forest-Their Odour-The Canadian OtterErroneously described by various Writers-Distinctions between it and European Otter-Its Habits-Otter Trapping-Trade in Otter Skins-Young Cubs . . . . . . . . . pp. 5-22

\section{CHAPTER II.}

Variety of Hares in North America-Absence of Rabbits-Distinctions between Hares and Rabbits-The Northern Hare-Weight and Description-Winter Coat-Change of Colour-Nature of Change -Doubts concerning it-Discrepancies of different Writers-Haunts of Northern-Hare-Its Latitudes-Abundance in certain DistrictsMalformation of Incisors-Habits-Attacked by the Lynx-Snaring and Trapping-When in Season-Poorness of Flesh-The Grey "Rabbit"-Its"general Appearance-The Prairie-Hare-Its Northern Limits-Abundance of Squirrels-Their Variety-Black Squirrels -Excellence of their Flesh-Grey Squirrels-Chipmunks-The Beaver-Former Habitations-Its Sagacity-Popular Fallacies concerning it-Formation of Huts-Gnawing down Trees-Compared with European Beaver-Its Skin-Method of Trapping-Excellence of Flesh-Present Districts of Beaver. . . . . . pp. 25-38 


\section{CHAPTER III}

The Moose-Parts of Canada in which it is found-Derivation of Name -Compared with Elk of Europæo-Asiatic Continent-Its early Distribution - Pleistocene and Prehistoric Remains - Gradual Diminution of the Moose-Wanton Destruction-Erroneously confounded with Ancient Irish "Elk" - Their Antlers compared-Antlers at Forglen-Form and Dimensions of the Moose, and general Description - Its Winter Coat-Growth of Antlers in different Stages-Manner of Feeding-Formation of the Muzzle-Its FoodPeculiarity of Hoofs_- "Cow"-Moose-Young Moose or "Calf"Modes of Hunting Moose- "Calling"-How performed-Response to- "Driving"-Gait of Moose when Pursued-Herding of Moose in Canada-" "Still Hunting"-Its Difficulties-Qualifications necessary-Herd at Rest-Summer Haunts-Destruction of Moose by Indians and Settlers- "Moose-Yard"-Besieged by Wolves-Winter Hunting-Snow Shoes-Bivouac in Snow-Rifle for Moose Shooting-Moose Flesh-Manufacture of Pemmican-Probable Longevity of the Moose-Preparation and Uses of Skins, Hoofs, and Sinews . . . . . . . . . . . . pp. 41-69

\section{CHAP'TER IV,}

The Caribou-Two Varieties-Compared with the Reindeer-Present Range of Reindeer and its former Latitudes-Early Existence in Western Europe-Remains found in France, Great Britain, and Ireland-Difference in Size between Caribou and Reindeer-Intractability of Former-Difference between their Antlers-Effect of Food on Antler Growth-Description of Caribou Horns-Not used for removing Snow-Antlers in Female-Immature Horns-General Description of the Caribou-Infested with CEstrus-Districts where found-Nature of its Food-Its Call-Stalking-Great FleetnessWinter Herds-The Wapiti-Its Southern Limits-Size, Colour, and Antlers-Misnamed "Elk"-Its Habits, Food, \&c.-The American Deer-Antlers and general Description-Colour of Fawns-Quality of Venison-Abundance of Deer-Where to be found-Their Food and Habits-Torch and Fire-light Shooting-Driving-StalkingSeasons for-Canadian Winter-Sleigh Drive to Forest-Still Hunting in Snow - Mode of securing Carcase-Value of Deer Skins 


\section{CHAPTER V}

Silence of the Forests-Interesting Birds-White-headed Eagle-Variety of Hawks-Musquito Hawk-Owls-Great Horned Owl-Snowy Owl-Absence of Birds in Winter-Snow-Birds-Esteemed a Delicacy-Their Resemblance to Ortolan-Arrival of Birds in SpringBlue-Bird, Harbinger of Spring-Scarlet War-Bird-Orioles-Humming-Birds-Familiar English Birds-Characteristics of CountryCanadian Forest-_" May-Apple"-Woodpeckers-Red-winged Starling-Absence of the Common Sparrow-Principal Feathered Inhabitants of the Forest-Game Birds of the Coverts and PlainsWaders and Water-Fowl-Game Seasons of the Upper and Lower Provinces - Their Discrepancy - Its Effects - Proposed Alteration . . . . . . . . . . . . pp. 107-117

\section{CHAPTER VI.}

The Passenger Pigeon-Its Periodical Flights-Great number KilledBreeding Places-The Wild Turkey-Probable Parent of Domestic Bird-Its Importation into Spain-Early Accounts of-MisnomersMexican Origin-Differences between Wild and Farm-yard BirdsNest and Eggs-Craftiness of the Hen-Young Birds-Association of "Gobblers"-Food of Wild-Turkey-Their Wanderings-Former Abundance-Present Haunts-Difficulty of approaching themSeason for Hunting-Their Game Qualities-Use of the DogGradual Extermination - The Grouse of Canada-The SpottedGrouse-Plumage and Habits-Female-Their Size-The PrairieHen-The Prairies-Fires on Prairie-Weight and Plumage of Prairie-Hen-Singular Call-Female Bird-Pugnacity of Male Birds-Breeding Season-Eggs-Young Birds-Season for PrairieHen Shooting-Dogs for-Size of Coveys-Food of Prairie-HenWinter Habits-Prairie-Hen sent to English Market-Flesh not Poisonous-Questionable Advantages of Acclimatizing-The Ptarmigan-Plumage in Summer and Winter-Where found-EggsThe Ruffed-Grouse-Habitat-Its Size and Appearance-- "Drumming"-Manner of Walking-Flight-Shooting Season-Unfit for Food in Winter-American Kalmias-The Colin-Erroneously called "Quail"-Its Plumage-Haunts-Call Note-Season for Shooting-Introduction into England . . . . . pp. 121-164 


\section{CHAPTER VII.}

American Bittern-Its general Distribution-Appearance-Eggs and Nest-Excellent Flesh - The Little Bittern - Golden Plover Different from European Bird-The Ring Plover-Highly Esteemed - "Killdeer"-The American Woodcock-Distinct from European one-Dimensions and Colouring-Its Range-Localities-HabitsSeason for Shooting-Coverts-Mosquitoes-Difficulty of Shooting -Dogs necessary-Migration-The American Snipe-Found in Bushy Ground-Compared with European Snipe-Nest and EggsMigration to South-Birds left behind-Shooting Season-Diminution of Snipe-Return in Spring-Curlew-Esquimaux CurlewSandpipers-The American Rail-Its Excellence-Plumage, Habits, and Flight . . . . . . . . . . . . pp. 167-181

\section{CHAPTER VIII.}

Extraordinary Quantity of Wild-Fowl-Number of Geese annually passing over Canada-Breeding Grounds in the North-British and American Species and Varieties of Anatidø-The Trumpeter Swan - Peculiar to North America-The American Swan-The Canada Goose-Annual Migration-Cautious Flight-Lost in Fogs-Domestication of-Return to Wild Life-The White-Fronted GooseGeneral Distribution of-Plumage-The Snow Goose-Note of Its Food-Delicacy of Flesh-The Brent Goose-Seaward FlightThe Wild Duck or Mallard-Driven southward in Winter-Stray Birds-Change of Plumage in Male-Methods of shooting-The Shoveller-Flesh highly esteemed-Form and Peculiarities of Bill -Handsome Plumage-Appearance of Young-Assimilation of Plumage-Similarity to European Shoveller-The Gadwall-Its Shyness and Cunning-Swiftness of Flight-Signification of "Gad- . wall"-Number and Colour of Eggs-The American PintailSuperiority of Flesh-Singular Change of Plumage-Feeding in the Forest-Sleeping on open Water-How to approach-Colour of Eggs erroneously described-The American Teal-Compared with European-Difference of Opinion concerning-Plumage of Male and Female-Large Size of Nest-The Blue-winged Teal-Rudeness of Nest-Excellence of Flesh-Dislike to Cold-Return in Spring-Peculiarity of Flight-Favourite Resorts-The American Widgeon-Different from European-Autumn Migration in Flocks 
- Spring Return in Pairs-Habit of Feeding by Day-Fondness for the Valisneria-The Dusky Duck-Peculiar to North AmericaNon-Migratory - Description of Female-The Wood-DuckSingular Habit of frequenting Trees-Nest and Eggs-Carrying Young-Latitudes of-Easily domesticated-Oceanic Ducks-The Eider Duck-Plumage-Female-The Surf Scoter-Peculiar to America-The Velvet Scoter-Difference between Male and Female - The Ruddy Duck-Colour of Plumage-Peculiar Form of BillDifferent Colour of Female-The Pied-Duck-Inferiority of FleshThe Scaup-Nature of Food-Origin of Name-Difficulty of approaching-The American Scaup-Not mentioned by NaturalistsDifference between this and former Bird-Comparative ScarcityThe Ring-necked Duck-Confounded with Tufted Duck-Colour of Plumage-The Buffle-headed Duck-Instantaneous Diving ofDifficult to Kill-Colour and Markings-Irregular Migration-Difference in Female-Found in Great Britain-The Harlequin Duck -Abundant in Gulf of St. Lawrence-Breeding Places-Neatness of Nest-Incubation-Males in Flocks-Excellent Flesh-Beauty of Appearance-Size of Female-Seen in England-The Canvas-back Duck-Well-known Delicacy-The Valisneria favourite foodResorts of Canvas-back-Colour and Markings-Compared with Pochard-Appearance in Canada-Numbers killed-Methods of Shooting-Accompanied by Widgeon-The Red-headed DuckSimilarity to Canvas-back-The Long-tailed Duck-Irregular Appearance of-Inferiority of Flesh-Tail-feathers-Common in Scotland in Winter-The Smew-Handsome Appearance-Hooded Merganser-A North American Species-Strikingly marked Smaller Size of Female-Red-breasted Merganser-GoosanderIts wary Habits-Diving . . . . . . . . . pp. 185-239

\section{CHAPTER IX.}

The Fisheries of Canada-Imperfectly known in this Country-Their great Extent and Value-Number of Salmon Rivers-Large Trade in Dried and Salted Fish-Their Exportation-Immense TakesImportance of the lesser Waters-Variety of Fish in the Lakes and Rivers-Former greater Abundance of Fish-Causes of the Diminution-Legislative Protection-Revival of the Fisheries-Great Consumption of Eels-Torchlight Spearing . . . . pp. 245-252 
E R R A T A.

Page 85, line 2 from bottom, for " a foot" read "three-quarters of a foot." " 88 , line 16, for " hart" read " hind."

"249, line 12, for "leave" read "lease." 


\section{L L U S T R A T I O N S.}

\section{COLOURED PLATES.}

THE WILD-TURKEY

Frontispiece.

THE PRAIRIE-HEN . . . . . . . . . . . to face page 144

THE CANADA. AND RUFFED-GROUSE . . . . . " 156

E R R A T A.

Page 113, line 2, for "thickly," read " dotted."

Page 294, line 15, for " a fish of another family," read " another fish of the family."

Line 16, same page, after the word "becoming," insert "so."

CANADIAN LAGOON

THE MOOSE . . . . . . . . . . . . . . . . 69

THE CARIBOU

AMERICAN DEER . . . . . . . . . . . . 102

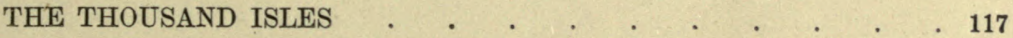

FORT MISSISSISAUGUA • . . . . . . . . . 164

FALLS OF MONTMORENCI . . . . . . . . . . 181

WOOD-DUCK . . . . . . . . . . . . . 239

EEL SPEARING, LAKE ST. FRANCIS \& . . . . . 252

THE CEDAR RAPIDS . . . . . . . . . . . 297

NIAGARA RIVER, AND LAKE ONTARIO + . . . . . . 312

LOWER NIAGARA RIVER . . . . . . . . . . . 326 



\section{L L U S T R A T I O N S.}

\section{COLOURED PLATES.}

THE WILD-TURKEY - Frontispiece.

THE PRAIRIE-HEN to face page 144

THE CANADA, AND RUFFED-GROUSE 156

THE WHITE-FISH 290

THE MASQ'ALLONGÉ . 308

THE BLACK-BASSE

\section{WOOD ENGRAVINGS.}

FALLS ON THE OTTAWA CANADIAN LAGOON

THE MOOSE

THE CARIBOU

AMERICAN DEER .

THE THOUSAND ISLES

FORT MISSISSISAUGUA

FALLS OF MONTMORENCI .

WOOD-DUCK

EEL SPEARING, LAKE ST. FRANCIS

THE CEDAR RAPIDS 



\section{DIVISION I.}

ftlammals. 



\section{CHAPTER I.}

\section{?apacta.}

DECREASE OF CARNIVORES-THE BLACK BEAR-ITS PRESENT HAUNTSDISTINCT FROM BLACK BEAR OF EUROPE-PERIOD OF HIBERNATION -ITS DURATION-FEMALE BEAR-CUBS-HUNTING-FUR OF THE BEAR-MIGRATION IN SEARCH OF FOOD-BEAR KILLED AT NIAGARA -THE WOLF-DISTRICTS WHICH IT INHABITS-COMPARED WITH EUROPEAN WOLF - HABITS AND CUNNING - WOLF-HUNTING VARIETIES OF FOXES-THE RED-FOX-DIFFERENT FROM EUROPEAN ONE-THE CROSS-FOX-THE SILVER-FOX-TRADE IN FOX SKINSGREAT VALUE OF SILVER-FOX SKIN-THE LYNX-ITS INOFFENSIVENESS-VARIETY IN COLOUR OF FUR-POWER OF SWIMMING-FOODTHE WOLVERINE-THE PUMA-THE CANADIAN OTTER-ERRONEOUSLY DESCRIBED BY VARIOUS WRITERS-DISTINCTIONS BETWEEN IT AND EUROPEAN OTTER-HABITS-OTTER-TRAPPING-TRADE IN OTTER SKINS -YOUNG CUBS. 



\section{CHAPTER I.}

Carnitrora.

F all the mammals of the Canadas, few perhaps have receded before the advancing strides of civilization more rapidly than the Carnivores, which-though common enough but a few years ago-exist only at the present day in the most remote wooded tracts, and are yearly decreasing in numbers.

The most important and valuable among them, namely, the Black Bear (Ursus Americanus), has probably diminished less than other species, and is still not uncommon in the country lying between the southern side of the St. Lawrence, and Gaspé; and also in the district at the head-waters of the Ottawa, the scenery of which alone, with its foaming falls, rugged rocks, and noble timber, would well repay the journey thither. The motionless forests of stately pine, the still lakes, and the solemn silence of an utterly wild country, convey the impression of a land unchanged since the Deluge. A few Indians, or a stray lumberer with equally dark skin and even wilder locks, are the only signs of life; but the 
woods ikat stretch away north, east, and west, are ail inhabited by bears, wolves, foxes, and herds of deer.

The Black Bear of North America has been confounded with that of Europe, but it is a distinct species, and may easily be distinguished by its smaller head and the greater height of the forehead; its ears are also longer and its feet smaller than those of the latter animal. This Bear appears to be peculiar to North America, and no remains of it, as far as I am aware, have ever been found either in Europe or Asia.

Its usual winter retreat is in some hole among the rocks, or under the trunk of a fallen tree, and here it sleeps away the long cold months. The period of its hibernation varies in length in different latitudes, and also according to the variation in the seasons of particular years, commencing and terminating with the continuance of the snow upon the ground. With the she-bear this period is also that of gestation, which lasts for four months, and with a view to the future safety of her young, she gene. rally selects for her retirement the hollow of some trunk, broken off by the wind at a sufficient height from the ground to render approach difficult. The cubs vary in number from one to four.

As may be supposed, the bear, when deeply covered by the snow, is not very liable to discoverv; but in the 
summer and autumn months it has a habit of scratching the trunks of the trees with its claws, by frequently stretching itself, as the cat often does; and even without this indication of its proximity, the well-worn path which it makes between the nearest water and its bed in the tangled thicket or tall reeds soon betrays it. A mongrel pack of dogs, trained to the work, is employed to track and bring it to bay, afterwards teasing and attacking it while the hunter watches his opportunity for a deadly shot at the breast or behind the shoulder. On the discretion and pertinacity, rather than on the courage of these dogs, depends very much the safety of the hunter; for though naturally timid and inoffensive, the bear, when wounded or attacked, is a formidable antagonist to encounter, a full-grown animal standing about three feet high, and measuring frequently five feet in length.

The colour of the fur, with the exception of a light brown patch on either side of the muzzle, is of a uniform deep black over the whole body. The hair being very long, straight, and evenly laid, gives the coat a remarkably soft and sleek appearance, and the skins (though they do not fetch so much as they used to do) are always in request, whatever may be the fluctuations in the demand for other furs. They are especially in esteem as wraps for sleighing. Nothing can be richer and more handsome in 
appearance, especially when in contrast with the snow, than a set of "sleigh-robes" of black-bear skin, trimmed with scarlet. The summer hides are cut by the Indians into cords, which are used for a variety of purposes; and the claws are highly valued as necklaces. The flesh, which is much eaten by these tribes, is white, devoid of flavour, and rather greasy than fat. Mr. Ross, of the Hudson's Bay Company's Service, alluding to the extensive use of the fat as a pomatum, does not coincide with those who esteem it as a hair renovator, but on the contrary, says that when used pure, it is more likely to cause the hair to split and fall out.

The principal food of the bear consists of roots, wild fruit, acorns, nuts, masts, and berries of different kinds, chiefly that called the "blueberry;" and it is also in the habit of eating various kinds of insects. Though less carnivorous than vegetarian, it will, when pressed by hunger, occasionally carry off a young lamb or pig from outlying farms, but commits more serious depredation on the fields of young maize, thereby bringing on itself the wrath of the settler, by whom it is always remorselessly hunted down. The Indians are more superstitious in this respect, for as Sir John Richardson* says, "Many of the native tribes of North America will not join the chase till

* Fauna Borealis Americana. 
they have propitiated the whole race of bears by certain speeches and ceremonies, and when the animal is slain they treat it with the utmost respect, speak of it as a relation, offer it a pipe to smoke, and seldom fail to make a speech in exculpation of the act of violence they have committed in slaying it, although the hunter at the same time glories in his prowess. This veneration for the bear seems to have arisen from the ability and pertinacity with which it defends itself; and it is interesting to observe in how similar a manner the same feeling manifests itself in tribes speaking diverse languages, and widely separated from each other by geographical position."

Scarcity of food sometimes compels it to migrate from one part of the country to another, and even to venture into populated neighbourhoods. I saw one brought in to Niagara, which had been killed within a mile or two of the town, but it was in very poor condition, and had evidently got lost in searching after the food which its own forests no longer afforded.

The Racoon (Procyon lotor) though much more abundant in the United States than in Canada, is not unfrequent in some parts of the country, as in the districts of Argenteuil and Ottawa.

Not unlike the badger in general appearance, though with longer legs, it has a sharp, pointed nose, short 
round ears, and a bushy tail. In point of colour it varies a good deal, but is generally grey and different shades of brown, the hairs being tipped with black. Of two skins in my possession, obtained in Upper Canada, one is grey and brown mixed, the other entirely brown, with very dark extremities to the longer hairs. Along each side of the face is a brown stripe; the under parts are whitish, and the tail is marked with alternate black and yellowish-brown bars.

The Racoon preys upon wild ducks, for which it watches among the thick reeds at the edge of swamps, and also greedily devours their eggs; it has no objection to mussels and frogs, and like the bear, is very partial to fields of growing maize. As soon as its presence is thus discovered in the neighbourhood, the farmer takes advantage of the first moonlight night to compass its destruction by the aid of dogs trained for the purpose, which, casting about till they strike the scent, chase the animal to the foot of some large tree, in which it is its invariable habit to take refuge. The barking guides the party to the place, and the only difficulty then is to discover the object of their chase, which is sufficiently cunning to lie flat on the large branches and keep as much of its body out of sight as possible, so that without the aid of a blazing fire it is not easy to get a shot at it. The flesh is said to be excellent. 
The Wolf, in certain districts, is more abundant than the bear, as on the St. John River, and in many of the northern parts of the country. A considerable difference of opinion exists among naturalists, as to whether or not there is any real difference between the European and American animals. Richardson* distinguishes the latter as having a thicker fur and a more robust form than the other; a nose less pointed, and profile not so straight; with shorter legs and ears, and a more bushy tail. Baird $\dagger$ considers it difficult to occupy a middle ground between considering all the American wolves as one species with many varieties, or making all the varieties into as many distinct species. Until better means of comparison and determination indicate otherwise, he prefers to consider them all as one species, and assuming this to be distinct from the European one, which however is not yet proved, employs Richardson's provisional name of Canis occidentalis for it.

The variety now under notice (C. occ. var. griseo. albus), which is the only one found in Canada, is frequently observed to exhibit very different shades of colour ; generally speaking, however, it is of a reddishbrown tint, grizzled with scattered white hairs. The tail

* Fauna Borealis Americana.

† Report on Zoology of Pacific Routes: Wastington, 1857. 
is bushy, and the hair round the neck is considerably longer than on the rest of the body. It is gregarious, and also very uncertain in its movements, sometimes suddenly deserting a particular district without any apparent cause; or, after having long forsaken the neighbourhood, as unexpectedly reappearing, probably to the great loss and terror of some luckless settler's sheep.

Wild and cunning as the Wolf appears to be in its mature age, it is nevertheless easily tamed if taken young; instances are on record of its associating with common dogs, and learning from them the habit of barking; but its sagacity later in life renders its capture very difficult. Most other animals fearing danger from a trap would cautiously avoid it altogether, but the Wolf, with a perfect discrimination of its exact nature, carefully undermines it, so as to remove the bait from beneath, unhurt. With set-guns also they have been known to bite off the cord close to the trigger, and then devour the tempting morsel placed in front of the muzzle; and Mr. Ross, H.B.C.S., writing in the "Canadian Naturalist and Geologist," mentions the fact of a wolf having on more than one occasion hauled up the fishing lines set in a hole cut through the ice, and helped itself to the fish. They are in the habit of following the camps of hunters and Indians for the sake of the scraps and refuse; they also form them. selves into bands, and systematically hunt the deer and 
young moose with extraordinary cunning, and a display of what can only be termed forethought.

They are killed in considerable numbers by means of traps and pit-falls. The latter are holes about seven feet in depth, wider at the bottom than at the mouth; these are overlaid with sticks and grass at the beginning of winter, and when the snow has entirely covered them, the bait is carefully laid over the centre of the pit, falling into which the animal is easily despatched. On the prairies they are sometimes killed by large parties of Indians, who form a circle extending over many miles of country, and gradually approaching in a lessening ring, enclose frequently a number of wolves together, when they are destroyed with heavy clubs, tomahawks, and stones, and occasionally with guns; though there are palpable objections against shooting from opposite points of a small circle.

Among the several distinct types of Foxes belonging to North America one species only is found in Canada, which species (Vulpes fulvus) contains three varieties, viz., the Red Fox, the Cross Fox, and the Silver Fox.

The Red Fox ( $V$. fulvus) was till quite lately considered as identical with our common fox ( $V$. vulgaris), but they differ considerably, the Canadian animal being a good deal larger, and its colour a much 
brighter red, while the coat is also far longer, softer, and more silky. As with the wolf, its muzzle is not so sharp as in its European congener; the feet, too, are stronger and more completely covered with hair beneath. Lastly, the brush is darker and very much fuller, and is composed of an under fur, having long hairs growing through it; the tip being pure white. The chin is also white, a dark grey stripe runs under the throat and chest, and the anterior faces of the legs are black.

The Cross Fox ( $V . f$. var. decussatus), so called from a dark mark across the shoulders, not unlike that in the ass, is perhaps rather larger than the preceding; the sides and neck are a reddish yellow, and the legs and under parts of the body are black; the tail, which is very full, is of a blackish hue, the extreme point being white.

The Black or Silver Fox ( $V . f$. var. argentatus $)$ is a shining black, grizzled with silvery grey on the back, the loins, and the thighs, and less conspicuously on the shoulders and along the tail, the extreme tip of which is perfectly white, as are also the under parts and feet; they vary, however, a good deal in colour.

An important trade is carried on in foxes' skins, and large quantities are annually sent to England of all descriptions, those of the Cross Fox, and Silver Fox being exceedingly valuable; indeed, so great is the beauty of the 
fur of the latter variety, and the rarity of the animal itself, that a superior skin is worth as much as from $20 l$. to $30 l$.

Many of the remote forests, especially those on the southern shore of the Gulf of St. Lawrence, are inhabited by the Lynx, or, as it is generally called, CatamountLynx Canadensis. Naturalists are now inclined to return to the opinion of Pennant, that the Lynx of Northern Europe and this are identical. Though rather a large animal, measuring nearly three feet in length, with thick and powerful looking legs, it is harmless and inoffensive, and flies from man rather than face him; nevertheless, when brought to bay or met unexpectedly at close quarters it will set up its back and spit like a cat. It is, however, so easily killed, that an ordinarily severe blow with a stick is sufficient to despatch it.

Its appearance is too well known to need description: its disproportionately large hind-quarters, round head, and long ears tipped with tufts of black hair, being familiar to all. It varies a good deal in colour; sometimes it is a hoary brown, at others nearly grey, and often of different intermediate shades. The coat is very thick and close, and the under hair lead colour. The throat is white, and there are several very dark marks through the whiskers and on the sides of the neck.

The Lynx is hunted chiefly for the sake of its skin, 
which, however, is not very valuable, and the Indians eat the flesh, which, though white and tender, would not, as may easily be imagined in an animal of the cat kind, be at all appreciated by a European. It has a very unfeline pro. pensity of taking to the water, and swims remarkably well, sometimes crossing rivers of more than two miles in width. On land it has a singularly free bounding gait. It preys on birds, squirrels, or any other small animals that come in its way; it is a deadly enemy of the socalled "rabbit," and is said to be very destructive to young lambs.

The name "Carcajou" is erroneous as applied to this animal. It is used chiefly in the United States, to designate the glutton or wolverine, ${ }^{*}$ which belongs to another family, and is at the present day seldom heard of in either of the Provinces, inhabiting more generally the higher latitudes.

I have only seen, in Canada, one specimen of the Puma (Felis concolor), and that was shot a few miles from St. Catherines by Dr. Maitland, R.C.R.

It is a much larger animal than the lynx, though the head is smaller in proportion, while the tail, which is slightly tufted at the extreme point, is very long. The colour of its fur is observed to change at different periods

* Gulo Luscus. 
of the year, but is perhaps most commonly a yellawish brown, darker on the back, and greyish white on the belly.

This is the same Puma as that of South America, and in both continents is very widely distributed. In the United States it is styled a "Painter!" It is a most destructive enemy to sheep, killing sometimes scores in a single night, in apparent wantonness, and on this account has always been systematically hunted down by the farmers, so that it is not to be wondered at that it should have so greatly diminished in numbers in Canada of late years that at the present day it is only to be found in the largest tracts of wood, and at rare intervals.

Any one who has roamed much in the Canadian forest must have often come across the sickening trail of the skunk, ${ }^{*}$ called by the French Canadians Enfant du diable. This horrid little animal, which is of the weasel kind, has a beautiful coat of jet black, broadly marked with two lateral stripes of white; and on account of its extreme softness, as well as beauty, the fur is much sought after by dealers. But so disgusting and powerful is the odour emitted by this creature, that nothing can withstand it: no dog can be induced to approach the track it leaves behind, still less to attack the animal itself. I

\section{* Mephitis mephitica.}


have more than once, when shooting, been obliged to rush with suspended breath past the spot where a skunk had crossed, and on one occasion was compelled to beat a hasty retreat from a small inn near Chippewa, in consequence of one of these animals having been killed in the cellar several hours previously. In similar cases, it is said that any food in the place, even though not actually touched by the animal, is so infected by the penetrating scent, that it has to be thrown away. - Notwithstanding this offensiveness, its own flesh is said to be excellent. The odour, which the skunk emits as a means of defence from its enemies, proceeds from a liquid secreted in two caudal glands; these having been removed, the animal may be domesticated without fear, and cases are known in which it has become as tame as a cat. Its food is young birds, mice, frogs, and the eggs of ducks or poultry. Its strong and sharp claws enable it to burrow or to climb with equal facility; in winter, for instance, it lives entirely underground, but forms its nest in summer and brings forth its young, which are six or eight in number, as often high up in a tree as in its hole.

The Canadian Otter (Lutra Canadensis), though common enough in all parts of the country, has for some unaccountable reason been singularly misrepresented by various naturalists. 
Goldsmith, contrasting it with the European animal, actually informs us that "it is usually found white, inclining to yellow!" According to Sir John Richardson, Cuvier has confounded it with the otter of Brazil; while Pennant* considers it identical with the common European otter; and Buffon describes it as differing from the latter in its size and hue. In the "Fauna Borealis Americana" its length is correctly given as "five feet, including the tail, which measures eighteen inches;" but in another work we are told that it measures only two feet in length, and that the tail is not more than ten inches long.

The principal distinctions between it and the common otter of our own country are its superior size, and the very much darker colour of its fur. This is a very deep brown, which in summer, and if the animal is in good condition, is often nearly black on the back, the upper side of the tail and on the legs; the under parts are lighter in their hue; and the sides of the head, the throat and breast are grey with a brownish tint. They are found to increase in darkness and depth of colour further north. A peculiarity also, which is not found in the European otter, is that the fur on the under parts presents the same glossy appearance as the upper. In point of size, the Canadian

* Arctic Zoology.

C 2 
Otter is considerably larger than the other, and its tail is also less taper.

In habits the two are precisely similar; they live in holes in the banks of lakes and rivers, preferring those waters where the bottom is stony; when unsuccessful in procuring fish will take almost anything that comes in their way, not refusing even a vegetable diet occasionally; but are dainty enough when their favourite food is plentiful, selecting only the choicest portions of each fish, and leaving the rest in disdain.

The Otter is sometimes shot at a considerable distance from the water, being in the habit of travelling during the winter from place to place in search of unfrozen streams, and for that reason is then most commonly found at the foot of waterfalls, or in the proximity of rapids. When surprised, away from its retreat, and especially in snow, it is very quickly overtaken; but it has an unpleasant habit of snapping savagely at anything approaching it, and its bite is very severe. I have heard an instance in which one, after being mortally wounded, left the marks of its teeth deeply indented on a gunbarrel. If it succeed in seizing a dog incautious enough to have come within range of its fangs, nothing will induce it to relinquish its hold, and even after death it is sometimes with difficulty that its jaws can be parted to release the victim. Notwithstanding this apparent 
ferocity, the Otter is in reality an animal of a naturally gentle disposition, and if taken young may be rendered so tame as to follow its owner. This I have seen in India; and there are, I believe, instances known in which the European animal has been trained to catch fish for its master.

In its own holes or in the water it is not easily attacked; there is no such sport as our otter-hunting practised or known in Canada, and the animals are generally taken by means of the trap. This is one size smaller than that used for taking beaver, and very strongly made; the ordinary method being to set it just under water at the foot of the "slide," or place which the Otter uses for getting into the stream. In setting this, the trapper is especially careful not to allow his hand to touch the bank or trees near, as otherwise the cautious animal would at once detect the danger, and carefully avoid the spot.

A great number of otter skins are annually imported into England, where they are always in request on account of the softness and beauty of the fur, which is exceedingly close and fine; they are also largely employed in the manufacture of the military caps and gauntlets which form a part of the officers' winter costume in Canada-the warmest and most serviceable articles of the kind I ever wore. The best 
skins are now selling at Quebec at not more than six dollars each.

The cubs, or young Otters, which never, I believe, exceed from two to three in number, are generally born in the month of April, they are soon able to shift for themselves and take to the water very early.

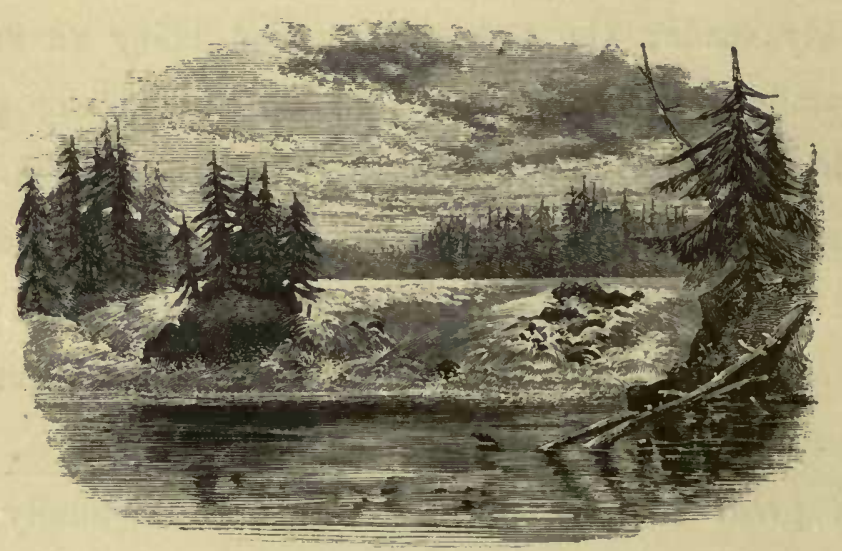

FALIS ON TIIE OTTAWA. 


\section{CHAPTER II.}

gavontix.

VARIETY OF HARES IN NORTH AMERICA-ABSENCE OF RABBITS-DISTINCTIONS BETWEEN HARES AND RABBITS-THE NORTHERN-HAREWEIGHT AND DESCRIPTION-WINTER COAT-CHANGE OF COLOURNATURE OF CHANGE-DOUBTS CONCERNING IT-DISCREPANCIES OF DIFFERENT WRITERS-HAUNTS OF NORTHERN-HARE-ITS LATITUDES -ABUNDANCE IN CERTAIN DISTRICTS-MALFORMATION OF INCISORS - HABITS-ATTACKED BY THE LYNX-SNARING AND TRAPPINGWHEN IN SEASON-POORNESS OF FLESH-THE GREY - "RABBIT" GENERAL APPEARANCE - THE PRAIRIE-HARE - NORTHERN LIMITS -THE BEAVER-FORMER HABITATIONS-ITS SAGACITY-POPUIAR FALLACIES CONCERNING IT-FORMATION OF HUTS-GNAWING DOWN TREES-COMPARED WITH EUROPEAN BEAVER-ITS SKIN-METHOD OF TRAPPING - EXCELLENCE OF FLESH - PRESENT DISTRICTS OF BEAVER. 



\section{CHAPTER II.}

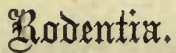

THOUGH the continent of North America furnishes

1 numerous species of hares, it is nevertheless entirely without the true rabbit, notwithstanding that many of the above are invariably so called.

Such confusion of two species, so plainly separated one from the other, by external characteristics, can only have arisen from the most careless observation.

Independently of size and colour, the hare is easily distinguished from the rabbit by the greater comparative length of its ears and feet, in which latter, by the way, there is also a slight osteological divergence. The rabbit burrows, while the hare always makes its "form" above ground; the latter is solitary, and the former gregarious; and the young of the hare are born with their eyes open and their bodies clothed with fur, while those of the rabbit are blind for nine days after their birth and are during that period entirely destitute of hair.

The common Hare of Canada, or Northern Hare 
(Lepus Americanus), though one of those generally denominated throughout the country a "rabbit," is in its habits and anatomy a true hare, and presents the following very distinctive characteristics of the species:-its legs are much longer than those of the common rabbit; there is a greater disproportion between the length of the fore and hind legs; and the eye is yellow.

In summer its general colour is a yellowish-brown, darker along the back and on the crown of the head; the throat and under parts are white, the sides of the muzzle are greyish, and there is a light patch or circle round the eye; the ears being tipped with black, which also extends down their edges. On close examination it will be found that the greater part of the hair is of three colours, viz., grey at the roots, brown in the middle, and very dark at the extreme points. The tail is white underneath and brown above.

The winter coat is rather longer than the summer one, and, with the exception of the ears, which remain unchanged, presents a uniform white appearance; though on blowing aside the fur it will be seen that the change goes no further than the surface, the grey roots and yellowish-brown centre remaining as in summer. In this respect it differs from the Polar-hare, the finer and softer fur of which is in winter pure white to the roots. 
Waterhouse* is of opinion that the white of the winter coat is not always due to change of colour only, but in some cases, as in the present instance, is accompanied by a partial shedding of the summer fur. Sir J. Richardson, however, attributes it entirely to a lengthening and blanching of the summer coat, but is of opinion that the change in beginning of summer consists in the winter coat falling off during the growth of the new fur. This can only be decided by examination of specimens at both seasons in their transition state.

The winter coat is gradually assumed in November, the head and shoulders being the last parts of the body to change their colour, and it remains unaltered until April, when it is shed. The young are later at both seasons in changing than the old ones are.

Dekay, $\dagger$ among other writers, affirms that this change of colour does not take place in the Northern Hare at all, and I have a letter now before me from Canada, in which the writer, a known sportsman, also states that it does not turn white. This contradiction may probably be explained by the fact that the change is dependent on the effect of climate as influenced by latitude. The animals in the States, doubtless, as Dr. Dekay says, undergo no change whatever, while those 
in latitudes removed a little further north exhibit it in a partial degree, and the complete assumption of the white coat commences only in Canada.

Other discrepancies, met with in various writers as to its size, weight, number of young, and so on, which are so puzzling and contradictory, may be traced to the adoption of different methods of measuring, and to the use in one instance of stuffed specimens, in another of freshly killed ones; to weighing at non-corresponding seasons of the year; and to the mixing up in various accounts, of this hare with the "grey-rabbit" or others, a confusion increased by the indiscriminate application of the term "Lepus Americanus." Hence it is that we find one author stating its length to be thirty-one inches, and another only half that; one informing us that it never weighs more than three pounds, another that its usual weight is between six and seven pounds. In one work we are told that it breeds four times in the season, while others affirm that it does so only thrice in the year; one says that it has not more than from two to four at a birth, and another, that it has from five to seven. The true length of a full-sized, freshly killed specimen, measured from the point of the nose to the root of the tail, is, according to the "Canadian Naturalist," nineteen inches and a quarter, and of smaller animals often only sixteen inches. Its weight varies 
at different seasons from three, to six and a half pounds, but five and a half pounds is the average weight of a full-grown one.

It is probable that the doe produces two families in the season, the young numbering from four to six each time, and the period of gestation is about six weeks; but this species is said to be subject to failures through a disease which is of periodical occurrence.

This Hare is found in pine-woods and in thickets on rocky hill sides and in undisturbed districts, preferring dry and rather high situations; and is generally to be met with, in greater or less abundance, wherever there is any quantity of dwarf birch or of willow. In the summer the chief part of its food consists of grass and the leaves of various plants. It is said to be very fond of the young twigs of the Laurus benzoin or wild allspice; and in winter scratches up the snow to feed on the berries and leaves of various species of Pyrola.*

It ranges as far north as latitude $68^{\circ}$, and, according to Dr. Bachman, $\nmid$ its southern limit is $51^{\circ}$; but $I$ have myself seen and shot it at the Short Hills, in the Western Province, which is about $43^{\circ} 15^{\prime}$, and it is common still further south in many parts of the State of New York, to my own knowledge. It is very abundant 
in many districts of both Provinces, and in those of Rimouski, Gaspé, and Bonaventure, is the commonest animal in the woods.

I have seen a specimen of this hare presenting an instance of a malformation of the front teeth, or incisors, which is not uncommon, namely, a growth of several inches in a circular direction. This, in the case of a single tooth, is owing to the absence of the opposing incisor, the constant friction of which, when in its proper place, keeps down the growth intended by nature to supply the daily wear to which the teeth are exposed. When, as is often the case, both an upper and lower incisor are similarly lengthened and distorted, it will be found to be owing to a divergence of their points.

It is not the case, as has been stated by some writers, that these animals when pursued take refuge in a hole, or in hollows under old roots ; on the contrary, they are not easily run down, even by dogs trained for coursing. They never burrow, and are generally to be found lying out among the long tufts of grass, though in cold weather they keep under the shelter of close bushes, or the foliage of fallen trees. Their hours of feeding are during the night, but a curious and wonderful instinct teaches them to foretell the coming of storms hours in advance, and to go forth at mid-day to procure the subsistence which they may, a little later, be unable to 
obtain. In the spring and summer it is not unusual to see them out early in the morning, or at sunset.

Great havoc is caused among their numbers by their natural enemy, the lynx, which subsists almost entirely upon them. As the runs or paths that they make through the woods are even more marked and permanent than those of our own hare, they are also very extensively snared in the remoter districts by the Indians, who make use of the skins in the manufacture of their winter clothing, and are also taken by means of a trap of thick pieces of bark, which, being saturated with salt, the animal attempting to gnaw, brings down on itself.

A friend in Canada informs me, that "among the country people it is not considered fit for food till after the first frost, but that the flesh is, at the best, in poor repute in the cuisine, being hard and dry, and is looked upon with disdain as a dish, except in a potage with plenty of other ingredients."

The "Grey-Rabbit" (L. sylvaticus), which Desmarest, Harlan, Audubon, Thompson, and Bachman call $L$. Americanus, in general appearance very much resembles our common rabbit. Its back is a yellowish-brown, mixed with grey and black; the sides being much greyer, as well as the loins and thighs. The under parts are white, and the sides of the head reddish grey. The fur is full and close, and especially so on the under parts of the feet. 
The Prairie Hare ( $L$. campestris) is one of the largest hares of the continent, weighing from seven to eleven pounds, and is of a grey colour tinged with yellow, the entire under parts dusky white. It does not burrow, and is found by the sportsman, like the two preceding kinds, either with or without the use of dogs.

The forests in most parts of Canada abound with squirrels, which are perhaps more abundant and in greater variety in North America than in any other part of the world, widely distributed though they are. A large black one, ${ }^{*}$ fully double the size of our common red squirrel, is so numerous at times, that scores may be seen leaping from bough to bough. The flesh of this kind, especially after the hickory nuts come in, is not to be despised, being very white and tender, and of delicate flavour. I have occasionally killed them when on short commons, and consider the flesh, either stewed or made into a curry, as equal to rabbit, and have passed it off as such; on one occasion eliciting the highest commendations of a brother officer, who had often expressed his disgust at the idea of eating squirrel.

Black-squirrel shooting ranks as a field-sport among the Yankees, whose aspirations, however, do not rise very high in such matters ; and there are authenticated 
instances of two guns having killed upwards of one thousand head in a week. The grey-squirrel,* which is even larger than the above, does not appear to be so common, though I have seen it in tolerable abundance, and it is much sought after for the sake of its beautiful skin, which is used in the manufacture of caps, muffs, and other articles of winter attire. Both these squirrels are migratory, and move to the south when the cold weather sets in. The black one is a capital swimmer, and does not hesitate to cross the widest rivers in his course, though I cannot bear out the report which gravely states that "they are accustomed to cross the great lakes, using their tails after the manner of a sail, and choosing a favourable wind."

An exceedingly pretty and very interesting variety, which is familiar to all who have been in the forest, is the ground-squirrel, or "chipmunk," $\dagger$ which may be seen in almost every wood. It is smaller than the common British squirrel, with a tail much less bushy in proportion. A specimen that I brought home is of a bright fawn colour, inclining to grey on the back, along which run three parallel stripes or bars at a little distance apart, the two outer of a light cream colour, with a border of deep brown, and the centre one of the latter colour only.

* Sciurus leucotis. + Tamias striatus. 
The eyes, which are very prominent, are black and piercing. Its nest is generally to be found at the root of a tree or in the hollow of some fallen trunk, and is neatly and very firmly built of small twigs and dead leaves, the interior being warmly lined with abundance of dry moss, and so ingeniously covered in as to be perfectly protected from the heaviest rain. The chipmunk, I believe, rarely climbs like the squirrel, for I have often, when lying in wait for ducks or posted at some deer run, watched their amusing gambols, and observed them continually leaping on and clinging to the trunk of a tree, now and then scrambling a few inches up it, but dropping to the ground ugain without ascending higher.

The Beaver (Castor Canadensis) perhaps barely comes under the denomination of game, being more usually trapped than shot; but an animal so interesting deserves more than a mere passing notice.

Though once spread over the whole of Canada it is now found only in the most northern districts, and would doubtless ere this have become altogether extinct but for the fortunate stop put to the demand for its skin, by the introduction of other materials in the manufacture of hats; indeed, since this change, the beaver is said to be rather on the increase.

Traces of their former habitations are still visible in many of the most cultivated and populous parts 
of Canada. In one of these interesting remains near Niagara, called "Beaver Town," the dam-which they invariably erect across streams in which the supply of water is liable to be cut off-is of such large dimension and regular workmanship that at first I could hardly be persuaded it was not the work of human hands.

The skill and sagacity of these animals in the erection of their dwellings can hardly be over-rated; for the ingenuity shown in the prosecution of their labours appears to be rather the result of thought and reflection than of mere instinct. But many plans and devices have been attributed to them of which they are perfectly innocent. For instance, it is a fallacy to suppose, as many do, that the Beaver drives in stakes, or that it first forms a framework of wood, and then plasters it; neither is it a fact that its hut is made with back and front doors, or that in finishing its house it uses its tail as a trowel, constantly dipping it into the water, and smoothing the clay surface like a plasterer.

The flapping of the tail, which has given rise to this vulgar error, is a habit which the Beaver indulges in as much on the dry ground or tree-trunk as on its own house-top. The exterior of the hut is certainly most neatly plastered over, and the wonderful sagacity of the animal teaches it annually to replaster the structure before the setting in of winter; but the original build- 
ing is all made at one time, and is done entirely by the paws, which are also used in carrying both mud and stones. Wood is usually brought in the teeth, unless large logs are required, in which case they are floated down stream to the desired position. Beavers are popularly supposed to fell large forest trees, but they never attempt one above two feet in circumference, at the utmost: and this is sufficiently wonderful, especially considering the extraordinary neatness and celerity with which the work is done. It is a curious fact that they thus fell and prepare the wood required for new huts, early in summer, though they do not use it till the autumn.

The greater part of their building operations are carried on at night, and their unity of purpose and labour, and mutual assistance are not the least interesting traits of the animal which has been so well chosen as the national badge of the Canadians.

In the summer the huts are deserted, their inhabitants wandering about in search of food; before the frost commences, however, they reappear, and prepare their dwellings for the winter as above.

The cleanliness of their habits is most remarkable, and they are also exceedingly playful, the young ones especially gamboling like kittens.

The North American Beaver is probably rather larger 
than the European one, and the coat is generally darker, though the colour varies considerably in different individuals, even from the same colony; the form and position of the nasal bones also constitute an important osteological distinction between the two. Numerous fossil remains of the American Beaver have been discovered in different parts of the country, which do not differ at all from the existing species. The ear of the Beaver is very curious, being so formed as to lie flat when the animal is diving, thereby covering the orifice so completely as to exclude the water.

The "pelt" or fur is still in request among the trappers and Indians, who kill a great number of these animals in the course of the year. Some of the native tribes use the skins in the manufacture of their winter clothing, others merely as an article of barter and commerce.

The trap is baited, not with food, but with a scented oil, taken from the animal itself, and is set under water, fastened, like a common rabbit trap, by a chain to the bank, and having a float attached, by means of which, in the event of its being carried off by the Beaver's struggles, its whereabouts may be discovered. This oil, or "castoreum," as it is properly called, is also used as a bait for attracting the lynx and other animals.

The trappers esteem the tail a great delicacy, and the flesh of the young Beaver is really excellent, 
and very like that of young pig. The orthodox method of cooking it is to roast the animal in its skin, but as this is worth several dollars, it is not often that a trapper is willing to make the sacrifice.

The favourite food of the Beaver is the stem of the water-lily called Nuphar luteum; it also feeds upon the bark of several trees, as the poplar and birch, and especially the willow, and lays up a store for winter use.

At the present day, the Beaver is found on lagoons and streams in the country about Lake Superior, and the Roseau River. Eastward it is tolerably plentiful on many of the small tributaries of the Restigouche; and in the more remote regions of British North America is abundant.

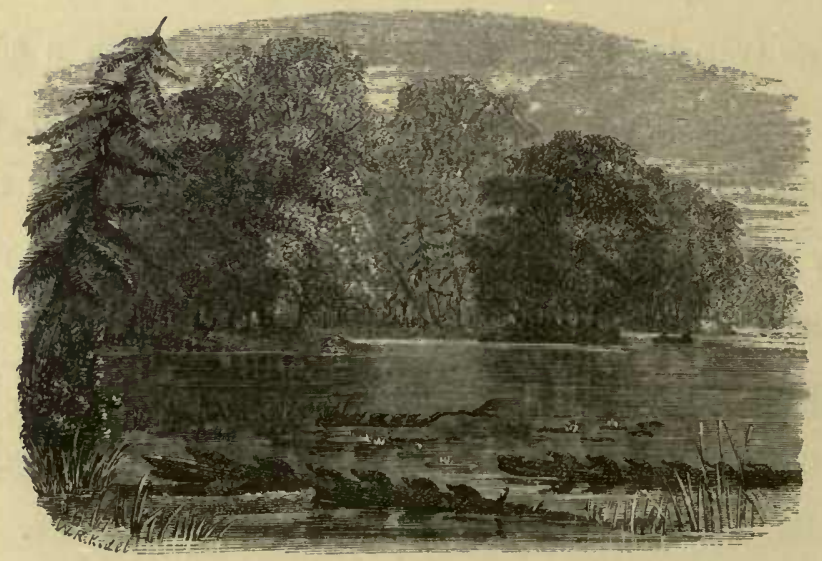

CANADIAN LAGOON. 


\section{CHAPTER III.}

\section{色uminantia.}

THE MOOSE-PARTS OF CANADA IN WHICH IT IS FOUND-DERIVATION OF NAME-COMPARED WITH ELK OF EUROPAO-ASIATIC CONTINENT-ITS EARLY DISTRIBUTION-PLEISTOCENE AND PREHISTORIC REMAINSGRADUAL DIMINUTiON OF THE MOOSE - WANTON DESTRUCTION ERRONEOUSLY CONFOUNDED WITH ANCIENT IRISH “ELK”-FORM AND DIMENSIONS OF THE MOOSE AND GENERAL DESCRIPTION-ITS WINTER COAT-GROWTH OF ANTLERS IN DIFFERENT STAGES-FORMATION OF THE MUZZLE-ITS FOOD-PECULIARITY OF HOOFS- "COW"MOOSE-YOUNG MOOSE OR "CALF"-MODES OF HUNTING MOOSE" CALLING"- " DRIVING"-GAIT OF MOOSE WHEN PURSUED-HERDING OF MOOSE IN CANADA-" STILL HUNTING"-SUMMER HAUNTSWINTER RESORTS- "MOOSE-YARD"-WINTER HUNTING-MOOSE FLESH -PROBABLE LONGEVITY OF THE MOOSE-PREPARATION AND USES OF SKINS, HOOFS, AND SINEWS. 



\section{CHAPTER III.}

\section{oduminantix.}

7 HOEGH greatly diminished in numbers during the 1. last half century, and year by year retreating within more circumscribed limits, the Moose (Cervus alces) still ranges the wooded country north of Quebec, away up to Hudson's Straits; is found eastward as far as the Saguenay River, and frequents in considerable abundance the districts of Rimouski, Gaspé, and Bonaventure. Westward of Quebec, it exists only on the northern side of the St. Lawrence, but below the city is found on both shores of the river.

The North American Elk, or Moose-the latter term being a corruption of the Indian synonyme "Moosoa"-I believe to be specifically identical with the Elk* of Northern Europe and Asia. For excepting that the Moose is of greater size than the European animal, there does not appear, on the most careful examination, to be any real difference whatever between them. The form and growth

* The term Elk (in Scandinavia Elch) is in America applied only to the Wapiti. 
of the antlers are closely similar ; ${ }^{*}$ the colour of the hair, the nature of the food, and the general habits of the two animals are precisely alike: and in Asia, where, I believe, they occupy nearly the same latitudes as in Europe, even the difference in size ceases to be observable, and the identity is complete.

Though, generally speaking, the latitudes inhabited by the European animal range rather higher than those occupied by the Moose, the climate and temperature will be found to be nearly the same in both cases. According to the just quoted writer, the entire range of the North American animal "extends, at the present day, on the west coast, from the shores of the Arctic Ocean nearly to the Columbia River. Further east, the northern limit is about latitude $65^{\circ}$, and thence through Canada to Maine, New Hampshire, Vermont, and the northern parts of the State of New York, where a few are killed every year, although, owing to the comparatively inaccessible nature of their resorts, their pursuit has become extremely difficult."

That the Old World Elk formerly covered a much more extensive area than at the present day, is manifest

* Baird, in his "Zoology of the Pacific Routes," says an extensive series of horns from Sweden, though somewhat different from the American ones he had compared with them, yet furnish nothing of apparent specific value. 
from the discovery of fossil remains in various European countries where it has been extinct for ages.

Mr. Boyd Dawkins says: In the turbaries of North Germany, and especially in Pomerania, its remains are very abundant, and are there associated with those of reindeer and other animals.

Even our own land appears to have been once inhabited by this noble animal, for its bones have been found in a cave on the coast of Pembrokeshire, associated with those of Ursus spelaus and the mammoth, proving that it lived in Britain, as it did in France, during the Pleistocene times. According to Dr. Percival Wright, an antler attributed to the true Elk was found in Ireland, and exhibited at a meeting of the Dublin Royal Society last spring. And the case adduced by Mr. Howse proves that this animal lived in England also after the disappearance of the mammoth, cave-lion, and other Pleistocene mammalia, in the period that, for want of a better name, we call prehistoric. In his "Notes on the Fossil Remains of Extinct Mammalia found in Northumberland and Durham," * he says, "The former existence of the true Elk or Moose Deer of the Canadians in England rests upon the authority of a very fine antler which was found in Chirdon Burn. The perfect appear-

* Trans. Tyneside Nat. Field Club. 
ance of the burr or boss shows it to have been shed, and the number of joints or digitations indicate it to have belonged to an individual six or seven years old, and therefore immature, as the Elk is said not to complete the growth of its horns till the fourteenth year. Though the above-mentioned instance probably belongs to the prehistoric period, the following quotation, if it may be relied on, would lead us to infer that the true Elk existed in this country at a much later date. In Maxwell's "Hillside and Border Sketches," it is said that a medal of Trajan, a patera, a fibula, and a Moose Deer were discovered near North Berwick. There is no historical account of the former existence of the Elk as a native of Britain by any Roman author, though it is particularly mentioned by Cæsar, among other animals, as living in the great Hercynian forest during the Roman period. With the progress of civilization, it has, however, gradually disappeared from the countries formerly occupied by this extensive forest, and occurs now in Europe only in northern Prussia, Lithuania, Finland, Russia, and Scandinavia."

Unfortunately this process of extinction is going on slowly but surely, among the Moose of Canada, aided by the yearly inroads upon the forest, and till lately by the barbarous destruction to which they have been exposednot alone on the part of the savage Indian or the ignorant 
settler, but, less excusably, at the hands of men claiming to be sportsmen, yet slaughtering indiscriminately old and young, pregnant mothers, and half-grown "calves," and leaving the useless carcasses to rot on the ground. Such deeds have been perpetrated to within a very recent period in Nova Scotia-deeds which, to the disgrace of our country, characterize the presence of Englishmen alike in the elephant jungles of the East, the buffalo prairies of North America, and the noble plains of South Africa. It is indeed to be feared that in time the Moose may become as completely extinct as its prehistoric congener, the so-called "Irish-elk," in comparison with which the proportions of the Moose sink into insignificance.

Perhaps some of the most perfect existing specimens of this magnificent deer are those in the possession of Sir George Abercromby, at Forglen House, N.B.; namely, two entire heads, with part of a third, and portions of four skeletons, which were found on his Irish property at Fermoy, at a depth of fourteen feet below the surface of a peaty swamp, resting on a solid bed of clay and gravel, and lying close together, as if washed in by some eddy.

These, or rather, similar remains, have often been erroneously confounded, under the name of elk, with C. alces; but the Irish "Big-horn," or Megaceros, is not 
an elk, but a true deer, intermediate between the fallowdeer (C. dama) and the rein-deer (C. tarandus); and its horns are of a very different type from those of the elk, which have no stem, and are also of much smaller growth.

The finest of the specimens of antlers just alluded to, at Forglen, measures no less than eight feet two inches across from tip to tip; the stems of the horns at base are nearly a foot in circumference, and some of the tines are two feet three inches in length.

Though of greatly inferior proportions to this colossal animal, the Moose is of far larger dimensions and more imposing appearance than any other existing species of the Cervida, though, at the same time, of such strange and ungainly form that we can hardly wonder at the absurd fables concerning it which are to be found among Greek and Roman writers; some of whom gravely describe it as having no joints to its legs, antlers growing from its eyelids, and only able to graze when walking backwards. Its habit, when pursued, of blindly stumbling over fallen trees and the like obstacles, owing to the elevated carriage of the head, also gave rise to the belief that it was subject to fits, and recovered itself by smelling its hoof.

A full-grown Bull-Moose stands from seventeen to eighteen hands high, and weighs nearly twelve hundred 
pounds. He has a bristly mane about five inches in height, and from a lump under the throat hangs a tuft of coarse hair. The coat is very long, and so exceedingly brittle that it breaks when bent. Except on the legs and belly, where it is of a much lighter hue, it is of a varying ash colour, having the extremities of the hairs tipped with dark brown. The tail is very short, and is white on the under side. In winter, unlike many other animals inhabiting the higher latitudes-as the hare and the fox, which at that season become as white as the snow on which they move-the Moose assumes a much darker shade, the bull being often nearly black, and consequently more conspicuous to his enemies; and this coat, which is not shed till spring, is much longer and coarser than the summer one.

The horns of the young Moose are in their first year only an inch high; in the next they rise to a foot, and are shaped somewhat like a large spear-head; in the following year they are forked; in the fourth season they have six snags, and at five years old are of triangular form, with points on the external edges. In the mature animal the points are sometimes thirty in number, and the antlers frequently measure as much as six feet from tip to tip. They are shed in January and February, and are so rapidly developed again, that by the month of June they are restored to their full size. The young males do not lose theirs till spring, and they are in consepuence corre- 
spondingly later in reappearing. A better idea of the size of the full-grown antlers may be conveyed by a comparison of their weight with that of the antlers of the Highland red-deer. These, in a full-grown stag, seldom weigh more than from twelve to thirteen pounds, whereas the horns of an old Moose often attain to fifty pounds and upwards, and have, I believe, been known to weigh as much as sixty.

The muscles of the neck are of extraordinary size and development, and the neck itself, as if intended the better to enable the animal to support the above enormous weight, is excessively short, measuring not more than twelve inches from the shoulder to the back of the head. The fore legs at the same time are disproportionately long, so that it can only graze with difficulty and in a posture apparently extremely irksome, one fore foot being awkwardly placed in front and the other thrown back under the body. That this attitude is really inconvenient is proved by the fact that whenever possible they give the preference to herbage lying on a slope, as being more easily accessible.

Nature has, however, in some measure compensated for so inconvenient a neck by the extraordinary length and prehensile power of the upper lip, or "mouffle," and also by endowing the animal with a liking for young twigs, tree-lichen, bark, and the tender branches of the birch, 
moose-wood and willow, which the giraffe-like formation of his body and limbs enables him to obtain more easily; while water-lilies, which are also a favourite food, he is likewise enabled to procure with facility by wading.

There is another peculiarity in this useful muzzle, namely, the formation of the nostrils, which are of such extraordinary size that I have heard of the lower end of a quart bottle being introduced into them without the slightest difficulty. The space between them is very broad, and almost entirely covered with close short hair, only a very small patch of bare skin being visible in the centre. The Moose, as is the case with most of the order to which it belongs, has no incisors in the upper jaw.

Though the fore feet are perfectly straight and wellformed, the hind hoofs, on the contrary, are splayed and awkward, and the horny points, which are very long and loose, strike together at every step with a singular clicking sound. This expansion of the foot is, doubtless, intended to support, to a certain extent, the weight of the animal on the snow-fields in winter, as well as on the vast swamps it loves to frequent in the heat of summer, though, on ordinary ground, it appears to increase the naturally somewhat shuffling gait.

Using their fore feet with great force and wonderful dexterity and quickness, they are enabled, with the heavy 
sharp-edged hoof, to inflict a most severe and often dangerous wound, and are therefore not to be rashly approached when wounded or at bay, though under ordinary circumstances they are by no means pugnaciously inclined. In fact, their natural disposition, as is the case with many other animals of great size and conscious strength, is rather to avoid combat than court it; and when taken young they may be easily tamed, in which respects they differ widely from the caribou.

The "Cow-moose" seldom exceeds sixteen hands in height, and has no horns; her coat is also redder or more sandy than that of the bull, though in both there is at times a very considerable variation of colour. She has only one calf at a birth for the first few years, but after that period has generally two. They are of a light brown colour, and are usually born in the spring, at which time the mother retreats to the deepest and thickest parts of the forest, chiefly in order to hide her young from the bulls, which would infallibly destroy them.

The calves continue to be suckled by the mother for a longer time after their birth than is the case with any other animal that I am acquainted with. They follow her likewise for a period of unusual duration; generally indeed until she has another family to look after. The slow growth of their horns as weapons of 
defence, and the time that the young animals are in coming to maturity, are thus compensated for by the maternal protection; for, as a recent writer* has noticed, the affection of young animals to their parents does not extend beyond the period when they are able to provide for themselves, and varies in its duration in accordance with the time necessary for attaining that end. Its intensity also ceases simultaneously both in parent and offspring, and after the period of its cessation not even recognition appears to remain.

During the rutting season, which is in September, the Moose seldom quits the covert, and is not to be approached without considerable risk, the bulls being especially dangerous at that time.

Moose hunting lasts throughout the autumn and winter, and there are several different methods of pursuing the sport, as "calling," "driving," "creeping," and "tracking," or hunting on snow-shoes, sometimes called "crusting."

"Calling," which is practised generally in September and October, as soon as the bellow of the bull begins to be heard at night, is thus managed, and though it may at first sight appear unsportsmanlike, is neither without danger or excitement. On a calm, light night,

* Thompson's "Passions of Animals." 
the hunter, accompanied by an Indian or Canadian, skilled, not only in woodcraft, but in the imitation of the call or bellow of the Cow-moose, repairs to the forest or swamp in which the animals are known to be feeding. The instrument by which the "call" is produced is a cone or trumpet of bark, generally that of the birch, about a foot and a half in length. With this the native mounts a tree, in order to enable the sound to travel further; the shooter below concealing himself either among the chance bushes, or, if necessary, behind an artificial screen of lopped boughs or sapins.

After the startling sound of the call has echoed away through the dusky forest, the ordinary deathlike silence again ensues, till the answer of the bull is faintly heard in the distance, for the range to which the call reaches on a still night is almost incredible.

When necessary to guide or encourage the advance of the approaching Moose, the call is repeated; but he generally makes straight to the point with wonderful accuracy, even from a distance of a mile or more.

The caller at this juncture, descending to the ground; retires, with a reserve gun, to the rear of the sportsman, and, motionless as the dark trunks around, they await the appearance of their prey. However cramped or constrained their attitude, they must not move a finger, for the suspicious animal invariably approaches up-wind if 
practicable, often making a very extended circuit to do so, and is not easily led into ambush.

Listening for the first response to the call, and still more anxiously for the slightest indication of an approaching animal, is a period of some excitement, but the moment the formidable beast is heard actually advancing nearer and nearer, crashing heavily through the obstructing branches in his onward course, now emitting a dull hollow grunt, now striking his antlers sharply against the trunks of the trees, every nerve is strung to the highest pitch, till the mighty tenant of the forest stands before the concealed hunter, who hardly dares to draw his breath as he steadies his hand for the fatal shot.

A bull, on approaching the whereabouts of the supposed female, will often stand in full view bellowing in tones that ring startlingly through the forest depths, stamping impatiently, and turning his shaggy head, now in one direction now in another, the large ears moving continually backwards and forwards, the mane erect, his enormous antlers glancing in the moonlight, and his breath wreathing in the night air.

When, as is sometimes the case, two bulls chance to meet at the spot, laying back their ears and gnashing their teeth together, they will rush at each other with the most sudden and appalling fury, roaring, bellowing, 
and clashing their antlers together in presence of the hunter, who, in utter forgetfulness of his rifle, stands rooted to the ground at the sight of the magnificent struggle.

Sometimes, also, an animal, on approaching, comes to a stand, apparently seized with vague doubts, and the caller lures him on again with a suppressed grunting sound, the imitation of which at close quarters is the most difficult part of the accomplishment. In this the "red men" are unrivalled; for though many of the French-Canadian hunters imitate the ordinary bellow very successfully, they are generally inferior in this most critical point. If the sounds are clumsily executed, the disappointed animal, though he would not hesitate, if confronted, to attack any one rash enough to meet him, takes alarm at an invisible danger, and beats a rapid retreat at the very moment when the anxious watcher is about to realize the reward of his toil and patience. When this unfortunately happens, the sport is over for the night, and there is nothing to be done but to light a fire and smoke, or lie down to sleep till a little before daylight, which is a very favourable hour for "calling," and by that time the alarm has generally subsided, or other moose have fed up to within call. A temporary bivouac is also not unfrequently rendered necessary by the sudden springing up of a breeze in the early part of the night. 
If the panic has been so complete as to prevent either "calling" or stalking with any chance of success, the Indians resort to "driving," and while the sportsman lies concealed in a likely "run," they make a considerable detour in order to get round the covert, and advancing through it, drive the animals towards the rifle.

When moving rapidly in this way the Moose carry their heads thrown back, their noses high in the air, and the hind legs wide apart, in order to avoid striking the heels of the fore feet, and, as may be imagined, have a most singular appearance as they shuffle swiftly away through the forest, twisting their huge horns in all directions to escape contact with the trees. Though their usual pace is a slouching trot, they can, when necessary, gallop; but, except when very hard pressed and on firm ground, seldom exert themselves to that extent; their ordinary pace, easy as it appears, being sufficient in most cases to distance their pursuers.

It not unfrequently happens that a small herd is ascertained to be feeding in some open glade at the edge of the forest, when of course it is simply necessary to advance cautiously up-wind under cover of the trees, and select at leisure the best or nearest, as the case may be. But they will never be found in such a position in thick or stormy weather; for though they are said by the Indians to hear the snap of a bough, even in the highest 
wind, the extra caution they exhibit in avoiding proximity to any covert under such circumstances, seems to argue the contrary.

"Creeping," or "still-hunting," which, except as affected by the nature of the country, differs in no respect from deer-stalking at home, may be followed both in autumn and in winter; though the former is certainly the pleasanter, and in some respects the better season of the two.

Few sports in the world, perhaps, more test the skill of the hunter than Moose-creeping, and I have stalked wildebeest and springbok on the plains of South Africa, the Great Rusa on the Neilgherry Hills, and alligators in Malabar (than which, not many animals more difficult of approach are easily to be found,) and therefore speak advisedly.

Shy and watchful as the deer, the Moose is even more cautious and keen of scent, and the eye, though so comparatively small, is extremely quick. The open forest, too, while certainly affording some degree of cover, adds difficulties unknown on the heather. Though not perplexed by the shifting winds of mountain corries, the hunter has to contend with the more dangerous stillness of the forest atmosphere, and the echoing distinctness with which every sound is borne on the clear air, and has to pick his hazardous path through clustering 
trees, over prostrate trunks, and among rotten boughs, where a chance blow from his rifle-barrel, or a careless step on an unnoticed stick, while he is eagerly noting the wind, the ground, the "sign," and fifty other essential points, may ruin in an instant results achieved only by hours of toil and exertion.

Nor are the feeding herd and watchful bull the only objects of his cautious regard. He must pay attention to the smallest birds and animals in their vicinity with equal care; for a chipmunk scampering through the dry leaves, or a chattering jay startled by his too sudden appearance or rapid advance, will probably scare away a whole herd, or excite such a degree of suspicion and alertness that further approach is a matter of doubly increased difficulty. These lesser inhabitants of the covert, however, often afford information of the greatest value to the practised hunter. Posted on a run, or crouched in his cache of green boughs, silent and alone, he knows that the bird darting suddenly from the thicket, or the squirrel abruptly arrested in his gambols, announces the unseen approach of the wished-for deer. The experienced in woodcraft discovers at every step signs to him as plain as day, where others see only accident or the merest trifles; he follows tracks invisible to unaccus. tomed eyes, with a sort of instinct; and pushes on with equal speed and certainty over dead leaves, elastic moss, 
and rocky ground. By the elevation of the newly broken twigs, by the height of the rubbings, or the appearance of the gnawed bark on the larger trees, by the form, the depth and size of the slot or footprints, by the droppings, connected or separate, he will tell whether the Moose in front are male or female, old or young; and knows their weight and antlers, and whether the animals are flying, or retreating leisurely. By the springy grass, still prostrate, or just recovering from the pressure of the hoof, he will judge his distance to a nicety, and by a hundred other minutiæ comprehend as clearly every movement of the invisible objects of his pursuit as though they were within reach of his eyes.

When Moose are close at hand, a faint warm whiff of musk scents the air, and he who has learned to thread his way with the stealthy tread of the panther may sometimes manage to creep pretty close in upon them. From the resemblance, however, in colour which their bodies bear to surrounding objects, it is often so difficult to detect them that the flapping of their long ears is the first indication of their whereabouts.

Some are lying, some standing; some stamping their large heavy hoofs, and others tossing back their vast antlers, impatient of the tormenting flies, which during the summer and autumn months attack them in myriads. If an alarm is given, in the twinkling of an eye 
everything is changed, the herd is off in a moment, madly rushing onwards, heedless of every obstruction, and bearing all before it. It is singular that the mere sound of firing does not appear to alarm other Moose in the neighbourhood; though the sight of a flying animal will scare away every herd in its course, and the forest will be deserted for days after.

In spring and summer, the Moose frequents the swamps and lagoons in search of rushes and aquatic plants, and in the hot weather stands, sometimes for a very long time together, immersed up to the neck in the cool lakes in order to escape the flies, or to browse on the broad lotus leaves floating on the surface, as well as on their stalks, which it procures by immersing its head under water. At such times they are much more easily approached-either in a canoe, or from the thickly wooded bank-than when in the forest; though the more common method is for the hunter to take up his position before daylight within shot of the place which he has previously discovered by the trail is a favourite resort. Here he lies in ambush as quietly as he can, seeing he is probably half devoured by musquitoes, till about mid-day, when the cracking of dry branches and the rustle of dead leaves warn him of the approach of the antlered monarch, which presently emerges from the shade, and after looking cautiously round, wades into the 
water, to fall an easy prey to the pot-shot of the patient watcher.

Even more illegitimate modes of destruction are unfortunately practised against these unoffending animals. The settlers hunt them at all seasons, with packs of yelping curs of every kind and breed, and though seldom successful in bringing them to bay, the country, after such runs, is entirely forsaken by the Moose for many months, if not altogether. The Indians also, when the snow is thickly crusted, which is generally the case late in the season, are in the habit of driving them into the deep drifts, where, being unable to escape, they are butchered in cold blood; and a system in vogue with the lumbermen is that of trapping them by means of a springe. This is formed by bending down a strong young ash tree, and laying a running noose of rope on the path they are found to frequent; by this means the passing animal is caught and hoisted up high in the air, where it struggles till the gradually tightening cord ends its painful throes.

In winter, the Moose, being, from their great weight, unable to travel without much difficulty in the deep snow, select some sheltered pirt of the forest, which also affords a good supply of food, and there form what is termed a "yard" or ravagé; not, as a writer on the field sports of North America tells us, "by regularly trampling 
down the snow in due form," but simply by confining themselves, for the above reason, to one spot, which, of course, very soon produces the same effect, the interior being screened and protected by the deep drift around.

Unless disturbed, they will remain in one of these places for a considerable time, gradually enlarging the area, often to the extent of twenty or thirty acres, and browsing on the bushes, and on the branches and bark of the surrounding trees, as long as there is anything left; the trunks being peeled to a height which it appears almost incredible the animal should be able to reach, while the young and lower trees are stripped bare of every branch; the spruce alone appearing to escape. The maple, mountain-ash, and "button-wood," or plane, are especial favourites.

There is little doubt that the Moose is capable of undergoing long privation, and in proportion to its great size is at all times a sparing feeder, and able to subsist on very little nourishment. The old males generally "yard" together, for as they advance in years they keep more and more aloof from the females and young animals; and at last become so unsociable that they even dislike each other's society, and live an entirely solitary life.

The exterior of the ravagé is often found thickly trampled by wolves, which, though mortally afraid to cross 
the rampart, will notwithstanding lay siege to the place night after night, howling round it with impotent rage.

Indians sometimes come in to report the discovery of these "yards," just as on the Neilgherries the Todas and Khotas come in to the European garrison to report a tiger, and, in like manner, parties are organized to go in pursuit ; but more generally expeditions start for the most likely districts, with the object of searching for and finding their own game, and are of course invariably accompanied by skilful guides and hunters. "Paul," and the elder and younger "Francis," Lorette Indians, who still act in these capacities, are names which will be familiar to all who have hunted Moose in the neighbourhood of Quebec.

Long and sometimes tedious marches through the snow, up hill, down dale, and through thick forest, have to be undertaken, and it is necessary to be prepared for an absence of several days.

After reaching the farthest point practicable for sleighing, or even using a calash through the narrow difficult paths, the camp supplies, blankets, biscuit, pork, coffee, and so on, are transferred to tarboggins, or light hand-sledges, which are drawn after the hunters by their dusky attendants. When the snow has accumulated to any depth snow-shoes are of course indispensable, but these are not to be used without 
practice, and even when their use has been mastered, a little preparatory exercise is advisable before starting on one of these expeditions, in order to accustom the ankles to the unusual strain upon the muscles, which, under the name of mal à raquette, frequently confines the tyro to his room. The snow-shoe, which it is perhaps hardly necessary to describe, is a light ash frame of an oval form, varying in dimensions according to circumstances, the full size being about thirty-nine inches in length by seventeen in breadth at the widest part, which is near the centre. This framework, strengthened by a couple of transverse bars, is laced across with a strong and beautifully made net-work of caribou or moose skin, which is cut into fine strips resembling catgut, and interwoven close enough to prevent the feet sinking even into the softest snow; this part of the work is generally performed by the squaws, the men manufacturing the wooden frame. When in use the snowshoes are attached by stout straps to the fore part of the feet; and if necessary while hunting, to remove them, in order to advance more noiselessly, are generally hung round the neck.

Each night the party bivouacs in the sombre snowladen forest:

"Manet sub Jove frigido venator ;"

and a convenient and sheltered spot being selected, the 
snow is dug out from an area proportioned to the shelter required, and piled up by the aid of the snow-shoes to windward, either simply as a screen, or in the form of a rude hut. The ground is strewed with sapins, buffalo robes are laid over them, and in front a blazing fire is built on large logs. Though this is comfortable enough, the latter part of the night is intensely cold; and in spite of blanket-coats, sleigh-robes, and fire, it is necessary to lie very close together to maintain the animal heat at all.

In Canada Moose more frequently form into small herds than they do further north, but it is not an uncommon occurrence to come unexpectedly on a single bull lying in the snow. As it starts suddenly to its feet and bounds forward, the novice in all probability fires a snap-shot at random, either missing it altogether or merely wounding it; but the practised hunter, knowing well that it will turn round in a moment or two to gaze at the cause of alarm, raises his rifle and steadily awaits a surer aim.

When a herd is in flight the animals keep in Indian file, each treading in the track of the one before it, for the crust on the surface of the snow, obliging them to lift their feet perpendicularly out of the deep holes made at each step, very much hampers their flight; while it is further impeded by the dogs used in the chase, 
which, barking close at their heels, yet always keeping out of harm's way, cause them constantly to stop and charge.

Though the hunter's broad snow-shoes bear him lightly on the glistening surface, while the flying Moose sinks to the knee at every step, it holds its own, and keeps the lead in a manner which, considering its awkward gait, appears incredible, and is not to be overtaken without a trial of strength and endurance which none but the robust need attempt.

Keeping to leeward of the tracks and cutting off all angles possible, the intervening distance is gradually lessened, and the excited hunters, straining every nerve, gain sensibly on their prize. Again, however, it struggles with more desperate energy through the crusted snow, its tracks stained with the blood that flows from its lacerated fetlocks, and once more regains the advantage. Strong thews, sound wind, and determined endurance, however, know no defeat, and the chase leads on and on, till at length the furious animal, with heaving flanks and distended nostrils, is brought to bay; or perhaps even till the descending sun crimsons the western horizon, and the quickly succeeding shades of night put an end to the pursuit till the morrow. With a two-year-old bull the latter is the more frequent occurrence of the two, as they have much greater powers of endurance than the others, but the old males, though more easily run 
down, are more dangerous and vicious when brought to bay; indeed they will sometimes even refuse to run at all, in both which cases a steady hand and dry powder are essential points. As to the weapon suitable for Moose, Caribou, and Deer shooting, a light double-barrelled smooth-bore rifle is, in my opinion, of all others the most convenient and useful; but every-one has his own ideas on these subjects.

When a Moose is slaughtered, the tongue, palate, mouffle, and marrowbones are reserved for the whitehunters, while their attendants feast on the flesh. This, though coarse in grain, is, when in good condition, very tender, and rather like beef, with the addition of a slightly gamey flavour; it is largely preserved by means of smoke-drying. The fat, unlike that of the deer tribe in general, is quite soft, and the layer on the chine, known as the depouille, is highly esteemed by the trappers and Indians; though that of the Caribou ranks, I believe, still higher in their estimation. The fat and marrow in both animals, when mixed with the pounded flesh, form "pemmican."

The Moose have been lately very much hunted for the sake of their skins, which have risen in value within the last year or two. Mr. Bell, of Montreal, in an interesting paper on the "Natural History of the St. Lawrence District," mentions the fact of a hunting 
party having, during the winter of 1857-8, procured three hundred skins; while another, consisting of only three Indians, had on a single expedition the same season killed nearly one hundred Moose.

The uses to which the various parts of this animal are put, says Mr. Ross,* are many. "The hide supplies parchment, leather, lines, and cords; the sinews yield thread and glue; the horns serve for handles to knives and awls, as well as to make spoons of; the shank bones are employed as tools to dress leather with; and with a particular portion of the hair, when dyed, the Indian women embroider garments. To make leather and parchment, the hide is first divested of hair by scraping; and all pieces of raw flesh being cut away, if then washed, stretched, and dried it will become parchment. In converting this into leather, a further process of steeping, scraping, rubbing, and smearing with the brains of the animal is gone through, after which it is stretched and dried, and then smoked over a fire of rotten wood, which imparts a lively yellow colour to it. The article is then ready for service. Of parchment, as such, the Indians make little use, but the residents avail themselves of it in lieu of glass for windows, for constructing the sides of dog-

* Can. Nat. Geo.: Montreal., Dec., 1861. 
carioles, and for making glue. The leather is serviceable in a variety of ways, but is principally made up into tents and articles of clothing, and in the fabrication of dog-harness, fine cords, wallets, \&c. The capotes, gowns, 'fire-bags,' mittens, and moccasins made of it are often richly ornamented with quills and beads. The lines and cords are of various sizes, the largest being used for sled-lines and pack-cords, the smaller for lacing snow-shoes and other purposes. In order to make the sled-lines pliant - a very necessary quality when the temperature is $40^{\circ}$ or $50^{\circ}$ below zero, Fahr.the cord is first soaked in fat fish-liquor; it is then dried in the frost, and afterwards rubbed by hauling it through the eye of an axe. To complete the operation it is well greased, and any hard lumps masticated until they become soft, by which process a line is produced of great strength and pliancy, and which is not liable to crack in the most severe cold. To obtain thread, the fibres of the sinews are separated, and twisted into the required sizes. The Moose furnishes the best quality of this article, which is used by the natives to sew both leather and cloth, to make rabbit snares, and to weave into fishing nets."

The long white hairs are used by the squaws in the ornamental embroidery of their different articles of clothing and finery; and the hoofs of the fore feet with about twelve inches of the skin attached, and flattened 
out, are manufactured into pouches, or bags called capuches, on which a large amount of labour and ingenuity is generally expended. The beautifully interlaced and durable net-work of the snow-shoes before alluded to, is made from carefully cut strings of the undressed or raw hide.

I have not been able to obtain any reliable information as to the longevity or otherwise of the Moose; it is, however, believed by the Indians to live to a great age, a supposition which, considering the tardiness of its attainment to maturity, is not improbable.

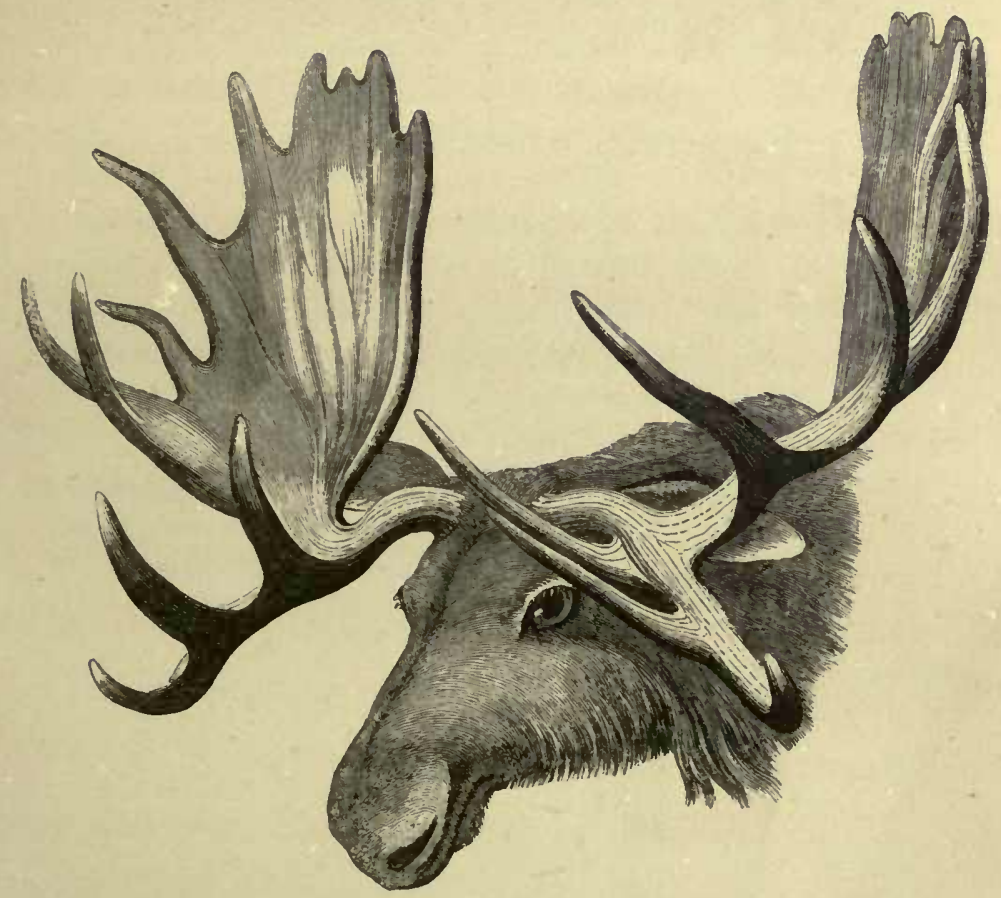

THE MOOSE. 



\section{CHAPTER IV.}

\section{ganminantia-continued.}

THE CARIBOU-TWO VARIETIES-COMPARED WITH THE REINDEER-PRESENT RANGE OF REINDEER AND ITS FORMER LATITUDES-EARLY EXISTENCE IN WESTERN EUROPE-REMAINS FOUND IN FRANCE, GREAT BRITAIN, AND IRELAND-DIFFERENCE IN SIZE BETWEEN CARIBOU AND REINDEER - INTRACTABILITY OF FORMER - DIFFERENCE BETWEEN THEIR ANTLERS-EFFECT OF FOOD ON ANTLER GROWTH-DESCRIPTION OF CARIBOU HORNS-ANTLERS IN FEMALE-IMMATURE HORNS -GENERAL DESCRIPTION OF THE CARIBOU-INFESTED WITH ASTRUS -DISTRICTS WHERE FOUND-NATURE OF ITS FOOD-ITS CALLSTALKING-GREAT FLEETNESS-THE WAPITI-ITS SOUTHERN LIMITS - SIZE, COLOUR, AND ANTLERS-MISNAMED " ELK"-ITS HABITS, FOOD, ETC.-THE AMERICAN DEER-ANTLERS AND GENERAL DESCRIPTION-COLOUR OF FAWNS-ABUNDANCE OF DEER-THEIR FOOD AND HABITS-TORCH AND FIRE-LIGHT SHOOTING-DRIVING-STALKINGSEASONS FOR-WINTER STALKING-MODE OF SECURING CARCASEVALUE OF DEER SKINS. 



\section{CHAPTER IV.}

\section{afuminantia-continued.}

THE Caribou of Canada (Cervus tarandus, var. Caribou)

1 is not to be confounded with the smaller variety (Groenlandicus) which inhabits the more northern regions lying between the sixty-fifth degree of latitude and the coast of the Arctic Sea; and is an equally distinct variety of the typical reindeer* of the Old World. As Sir John Richardson remarks $\uparrow-" N e i t h e r$ of these varieties of Caribou has as yet been properly compared with the European or Asiatic races of reindeer, and the distinguishing characters, if any exist, are still unknown. So great is their resemblance in habits and appearance to the Lapland deer, that they have always been considered to be the same species, without the fact having ever been completely established."

These remarks, written more than five-and-thirty years ago, are still true, for no complete skeleton of American Caribou exists in any European collection
* Cervus tarandus.
† Fauna Borealis Americana. I. 238. 
for comparison, and specific characteristics cannot of course be founded on mere antler variation; but I shall as briefly as possible point out the differences that exist between them, and show them to be in reality only very distinctly marked varieties of one and the same species.

The Reindeer has its modern range east and west, from Kamtschatka to Norway. Pallas mentions it as existing in the Ural Mountains in his time-namely, from 1760-80; and according to Wilson," "herds are still found among the pine woods which stretch from the banks of the Oufa, under the fifty-fifth degree, to those of the Kama. They proceed even farther south, along the woody summits of that prolongation of the Uralian Mountains which stretches between the Don and the Wolga, as far as the forty-sixth degree. The species thus advances almost to the base of the Caucasian Mountains, along the banks of the Kouma, where scarcely a winter passes without a few being shot by the Kalmucks, under a latitude two degrees to the south of Astracan. This remarkable inequality of the polar distances in the geographical positions of this species, according to the difference of meridian, is of course dependent on the laws which regulate the distribution of heat over the earth's surface, as explained by Humboldt. It is well known that physical climates 
do not lie, as it were, in bands parallel to the equator, but that the isothermal lines recede from the pole in the interior of continents, and advance towards it as we approach the shores. It follows, that the further any northern animal is naturally removed from the ameliorating climatic influence of the ocean, the more extended may be its range in a southerly direction."

In former ages the reindeer appears to have extended very nearly as far south as this in Western Europe also. There is no evidence of its having actually crossed the Pyrenees or Alps; but remains have been discovered at no great distance from the northern base of the former chain, and vast numbers of others have been traced thence through France, Great Britain, and Ireland.

In the caves of Bruniquel in Southern France, the Vicomte de Lastic found in a group of cave-remains immense numbers of those of reindeer, which had evidently served for food to the human denizens of the cavern, whose relics in skulls, bones, worked flints, and horns were afterwards secured by Professor Owen for the British Museum. In many of the caves of the Dordogne quantities of remains of $C$. tarandus have also been brought to light; in one instance an artificial flint weapon was found deeply fixed or embedded in a vertebra of one of this species. 
The Rev. S. W. King, F.G.S., discovered numerous remains in the cave of Aurignac in Haute Garonne, in 1864, where they had also been found to the probable extent of some ten or twelve individuals by M. Lartet, associated with Pleistocene remains.

Sir Charles Lyell* also notices remains as having been found in Brixham Cave, near Torquay, and in the ossiferous caves in Glamorganshire, from which latter no less than a thousand reindeer antlers were extracted, several hundred more being estimated to remain there.

- Professor Owent records their occurrence in a cavern in Devonshire, also in a peat moss in Norfolk, and probable specimens in a marl-pit in Forfarshire. Others have recently been dredged from the bed of the Thames.

In the West of England, Mr. Boyd Dawkins and Mr. Ayshford Sanford detected two varieties of fossil reindeer in the Pleistocene caverns of the Mendip Hills: one very large (query, Caribou?) the other very small, and corresponding with the extreme variety of $C$. tarandus-the Cervus guettardi of Cuvier.

In Ireland reindeer remains were found with those of mammoth, cave-bear, and brown-bear, in a cave near Dungarven. Professor Oldham records, as quoted by 
Professor Jukes, ${ }^{*}$ that in a cutting through a bog at Kiltiernan, near Dublin, in a layer of mud and vegetable matter, covered by sand, and again by peat, two heads of reindeer, with perfect horns, were found, together with heads and antlers of thirty elks (Megaceros Hib.); and in a note Professor Jukes adds, "I believe these horns were more like those of the Caribou (Cerf bouf) of North America than those of the Lapland Reindeer."

The latitudes which the reindeer frequents in the Old World at the present day,-viz., in Europe, from Southern Scandinavia to the Isle of Spitzbergen, and in Asia, throughout Siberia and Kamtschatka, are-with the exception of the Caucasian range before alluded tomuch higher than those occupied by the North American variety, which inhabits the tract of country lying between the southern shores of Hudson's Bay and the frontiers of Maine, extending westwards as far as the northern shore of Lake Superior; and it is a known fact that in both continents they increase in size as they are found further north; yet the Caribou exceeds in dimensions the largest Asiatic specimens. A mature male weighs, when gralloched, full $300 \mathrm{lbs}$, and measures upwards of six feet in length, standing also about ten 
and a half hands high; whereas the wild reindeer of Lapland seldom approaches within an inch or two of these dimensions, and the domesticated one is still smaller. This, however, may possibly be attributable to the effect of food, and facilities for procuring subsistence.

It is a remarkable fact that there is not a single instance on record of the Caribou having ever been tamed to domestic use, like the well-known friend and companion of the Laplander; on the contrary, even those that have been reared by the hand of man from their very birth, have invariably proved wild and intractable on attaining maturity.

The Caribou also differs from the reindeer in the formation of its antlers, which are less slender, and not so much curved as those of the latter. It is true that in both a considerable variation is common in this respect, even among individuals of the same herd; but the dissimilarity between the two varieties is of another nature, and neither casual nor accidental.

The size of the horns in all the Cervidæ is probably the result of food; if that be abundant then the antler growth reaches its maximum, and both diminish in a direct ratio. This curious fact is proved by the animals with the larger antlers being always found in areas where their food is plentiful, which is the case in a marked degree with the red-deer of our own country. 
Partly palmated and partly cylindrical, the Caribou antlers are of singular and fantastic form, and though of great expanse-apparently but ill adapted for a forest life-are so slight that their weight seldom exceeds $91 \mathrm{bs}$.

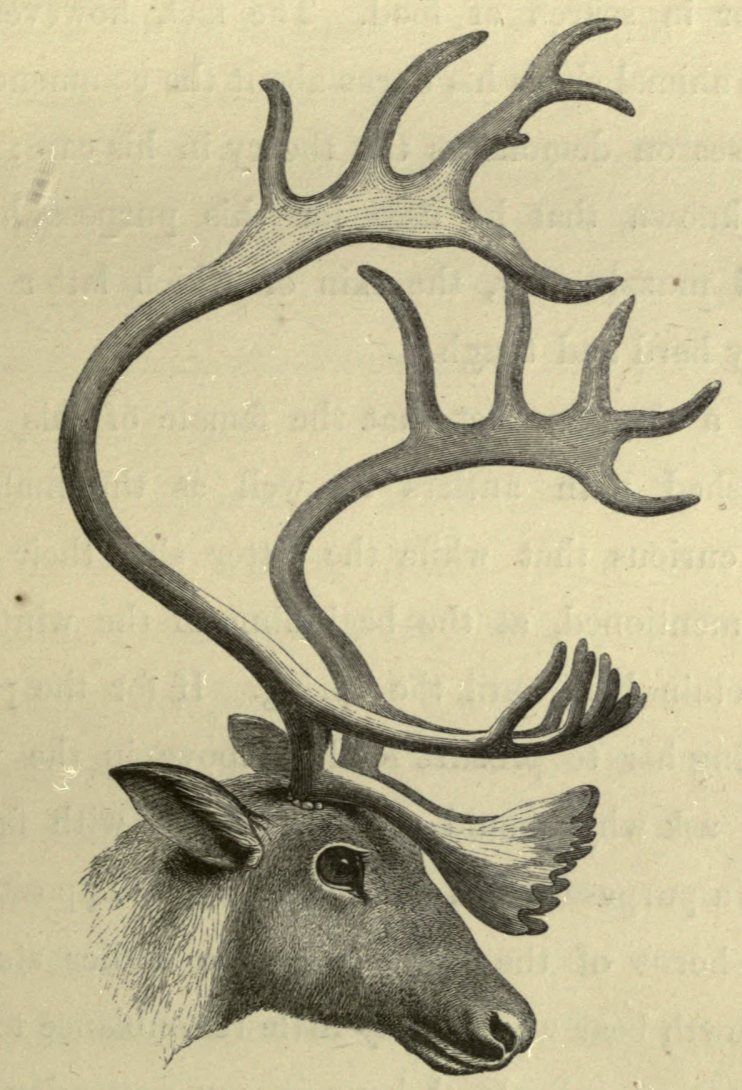

The stem of the horn is considerably curved, the concave side being to the front, and the extremities of the palmated brow-antlers project nearly fifteen inches over the face. Sometimes only one of these brow-antlers occurs on one or other of the horns, though they are 
more frequently present on both, especially in the case of the older males; and it is doubtless their peculiarity of form which has led to the belief that they are intended by nature for the purpose of removing the snows of winter in search of food. The fact, however, that the male animal sheds his horns about the commencement of that season demolishes the theory in his case; and it is well known that he uses for this purpose his fore feet and muzzle only, the skin of which latter is exceedingly hard and tough.

It is a singular fact that the female of this species is furnished with antlers as well as the male, and equally curious that while the latter shed their horns, as just mentioned, at the beginning of the winter, she should retain hers until the spring. If for the purpose of enabling her to procure food as above, in the winter, we may ask why should she be provided with facilities for such a purpose which are denied to the opposite sex?

The horns of the Caribou in the earlier stages of their growth bear wonderfully little resemblance to those of the mature animal. I have in my possession a pair which I brought from Quebec, believed to be those of a three-year-old, in which each horn is simply a plain, slender, and very slightly curved stem, bearing equally slender cylindrical brow-antlers, or rather tines, with no appearance of any tendency to palmate. 
The Caribou is not a graceful animal, having shorter and thicker legs and a larger head, together with less general symmetry, than most of the family to which it belongs.

The hair, which in summer is a reddish brown, becomes rougher and changes to grey in the winter, the throat and belly alone remaining white. Cuvier says,* "Il change, en général, du brunâtre au blanchâtre et au blanc; mais en qualité d'animal domestique, ses couleurs ne sont point constantes, et chaque individu a presque les siennes."

The coat is composed of two kinds of hair : an under one, of a woolly texture, which is very short, and so close that it is difficult to reach the skin, and an upper one of long straight hair of a darker colour. It is a peculiarity of the latter that when rubbed or roughly handled it breaks off short instead of coming out by the roots. The hair under the neck is long and pendent.

This animal is much infested in summer with the larvæ of the Estrus, which breed beneath the skin, causing open wounds, apparently very troublesome and even painful, and so numerous are they at times that the skin is worthless for any purpose of manufacture. As Mr. Ross, before quoted, states, "The only hides service-

* Ossemens Fossiles, p. 125. Paris. 1835. 
able for converting into leather are those of animals killed early in the winter, which, when subjected to a process similar to that detailed in the case of the moose, but bleached in the frost instead of being smoked, furnish a most beautiful, even, and white leather."

The districts in which the Caribou is now most commonly found are the wilds north of Quebec, and the country about the upper waters of the Restigouche, and here they are met with in considerable abundance, roaming the picturesque forests and solitary tracts in small herds or broken parties of six or seven ; seldom or ever being seen singly, like the moose. Mr. Robert Bell, in his Report on the natural history of the St. Lawrence District, already mentioned, states that they are also very common in the Shick-shock range of mountains in the Eastern province, and that "some of his party reported having found on the extensive table-top of Mount Albert, one of this chain, a large area covered with immense quantities of Caribou horns, most of them evidently of great antiquity." Mr. D'Urban also, in his Report on the fauna of the Valley of the River Rouge, says the Caribou is found in the districts of Argenteuil and Ottawa, on Trembling Mountain, "the gneiss rocks of which are covered with its peculiar food, the Cladonia rangiferina."

This lichen is what the settlers call "white moss;" 
another kind is found on the trunks of forest trees, to which the Caribou is also very partial, though it occurs more sparingly. When neither are to be procured, grass, leaves, bark, buds, and young twigs, are readily devoured. Its flesh is tender and well flavoured in the early winter, and is considered superior to that of the Moose.

The call of the Caribou is a sort of bark, though it is not often heard, and would hardly be recognised by one unaccustomed to it.

Though not so suspicious as the less agile moose, this animal is not to be approached without great care and circumspection on the part of the stalker, who, as on all similar occasions, is better with no other companion than his Indian guide. Many a disappointment has been caused by the indiscretion or ignorance of a friend and fellow-hunter, or by the presence of more attendants than necessary. In following up either Moose, Caribou or Deer, it is well always to bear in mind the advice given by Scrope.* "In all cases of approach, when it is necessary to advance in a stooping position, or to crawl, you had better keep a constant eye upon the man in the rear, for, believe me, no man is implicitly to be trusted. One will most unconscionably put his head up because, forsooth, his back aches insupportably;

* Deer-Stalking in the Highlands. 
another likes to have a peep at the deer; a third (and he is the most unpardonable of all) does not like to have the burn water enter the bosom of his shirt, which is very inconsiderate, as nothing tends to keep a man more cool and comfortable than a well applied streamlet of this description. So look back constantly to the rear, that every gillie may do his duty, and observe that no man has a right to see the deer in approaching to get a quiet shot, except the stalker."

In point of swiftness, the Caribou possesses a great advantage over the moose; and partly from its lighter weight, partly from its feet being larger and wider, is able to travel over snow which would not bear the weight of the other, while at the same time it is gifted with greater powers of endurance; whence it is that they do not form "yards" like the moose. On the contrary, they collect together as soon as the snow comes, and form wandering herds, which vary in number from a dozen to a hundred, though often attacked and dispersed by the wolves.

If it fairly takes to flight, it is useless to attempt to follow the Caribou, even on snow-shoes, unless when there is a crust on the surface sufficiently strong only just to break through with its weight at every step; this, lacerating the animal's legs, and so crippling its movements, places it more on an equality with its pursuer. The 
females, however, being generally fatter than the males, are more easily run down. The prints of the Caribou footsteps in the snow resemble those of a bullock, though they are longer.

In the summer and autumn, if pursued, the Caribou betakes itself, whenever practicable, to the nearest swamp as a refuge. If pressed, its pace is very rapid, and it takes extraordinary leaps in its stride; at such times, however, it will occasionally turn and stand at bay, showing fight with the utmost determination. When moving quickly the same sharp clicking sound is made by the hoofs which has been previously adverted to in describing the moose.

The Wapiti (Cervus Canadensis) would appear, from its specific name, to be entitled to a place among the large game of Canada, but is, in fact, found no further south than the limits of the North-West Territory; ranging as far as $56^{\circ}$ or $57^{\circ}$ in the opposite direction. It is, however, so beautiful an animal that I gladly avail myself of its name to give a short description of it.

Though frequently classed under the genus Elaphus, it is included by Baird in the present one, as keeping all the deer with naked muzzles together.

It stands about four and a half feet high at the shoulder, or nearly a foot higher than the red-deer of Scotland, though in general form both are very 
similar. In summer its prevailing colour is a light chestnut red, darkest on the neck and legs, the throat and centre of the belly being almost black; the chin is dusky, with a narrow patch of light yellow on either side, and a broad one of the same colour under the head. The rump is yellowish white, bordered by a dusky band extending down the hind legs; the hair is very brittle, and the tail much shorter than that of the European stag. In autumn it turns grey, and continues so through the winter. The ears, though large, are shorter in proportion to the size of the animal than those of the moose, and are more sharply pointed. The antlers, which are exceedingly handsome and of great size, often between four and five feet in height, are cylindrical, brown in colour, and of very rough surface except at the points, which are worn quite smooth and white. All the snags spring from the anterior face of the horn: the longest two from the base, the one above the other; while two and sometimes three others spring at nearly equal distances higher up; they are usually shed in March and April. In the young animals Baird* describes the horns as being "club-shaped spikes, truncate at the end, curved as in the adult, and without branches."

* Mammals of North America. 
The Wapiti is called the Elk in most parts of North America, excepting the Hudson Bay districts, where it is called the Red-deer: a confusion of names which has given rise to equal confusion in the various accounts and descriptions of the animal. Similar misnomers are of constant occurrence in North America, though I must confess that even in India I have heard the large deer of the Neilgherries also called elk.

The Wapiti move together in herds, keeping in covert during the daytime, and likewise when not feeding. They are not so cautious and watchful as either the moose or caribou, and are consequently less difficult of approach. Their principal food is grass and the young shoots of the willow and poplar. The flesh is coarse, but the skin is more valued as leather than either moose or caribou hide.

The common Deer of America (Cervus Virginianus), though very generally called "Red-deer," is not to be supposed as at all similar to that inhabiting the Highlands of Scotland. In its slight and graceful form it more nearly approaches the fallow-deer, but the horns differ widely in form and growth from those of either.

The principal stems bend backwards from the base, and then curve forwards and outwards, with from three to five points or tines on each, the basal ones springing from the anterior face of the horn, the remainder from 
the upper edge of it. In several fine specimens of mature antlers which I brought home with me to this country there are only three points on each horn. The general surface of the antlers is also smoother, and the colour lighter, than those of the red-deer, and their weight is never more than six pounds, and probably on an average about a pound or a pound and a half below that, whilst the antlers of the Scottish animal reach to twelve pounds or even more. They are usually shed in January or February, begin to appear again in May, and are fully grown by the end of August or the beginning of September. In young animals the horns may of course be seen in every stage of development, from a simple spike upwards.

In point of size the American Deer is decidedly inferior to the Scottish hart, being about four inches lower at the shoulder. Its colour is yellowish red during the summer and autumn months, paler on the sides, limbs, and front of the neck. In the winter it changes to a roan or greyish chestnut, though during both seasons the under parts remain white. In some animals a patch is observable round the eye, of a much lighter colour than the general surface of the body.

The hair in summer is thin, but the texture of the winter covering is very extraordinary, each individual hair being thickened, in appearance resembling crumpled 
quills, which, when pressed, either break off short or remain in a bent position. The tail, which is very full, is white underneath; the point of the chin and the sides of the muzzle are also white.

The hind has one fawn, and occasionally two, at a birth, generally late in the spring. During the earlier months of their existence the young are marked with white spots, which, however, gradually disappear as they attain maturity.

The flesh of the Deer, when in season, is tender and well-flavoured, but generally rather lean, though it frequently happens that it is condemned on that score very unjustly, owing to its having been killed at an improper time. A hart at certain seasons is quite unfit for food, and for several weeks afterwards does not entirely regain its normal condition, while a hind that has a calf never has any fat whatever; yet both are constantly killed at these times by traders and Indians, and sent into the market in a state of course inferior to the poorest mutton.

The Deer is common in Upper Canada, though less abundant in the western portion of the Lower Province, and below Quebec is unknown on the northern shore of the St. Lawrence. At the present time it is plentiful in the Upper Ottawa country; to the north of Lake Simco; and in most of the unfrequented districts or uncut and remote forests in Canada West. In many of the more 
open woods, where there is a luxuriant undergrowth of fine grass, they are abundant; and as it is their habit to return daily to the same spots, and even year after year to frequent the same haunts, the hunter may in such districts calculate with tolerable certainty on finding them. The tender shoots and young leaves of many of the trees of the forest are likewise a great attraction, they also feed on the pendent lichen which grows in such weird-like fashion on the branches, and, according to Mr. D'Urban, the Indians declare that "they are very fond of the leaves of the Kalmia angustifolia, from eating which they become intoxicated, and are easily killed."

Their general hours of feeding are in the early morning, before the sun is high, and again in the cool of the evening. In summer, during the heat of the day, they lie under the shade of the trees, often creeping in under quite low bushes in order to escape the persecution of the flies, they also frequently bathe in the lakes about noontide. If there is not sufficient water in the neighbourhood for this purpose they content themselves by repairing about the same hour to the nearest spring or stream to quench their thirst-a habit of which Indians and others do not neglect to take advantage. In the spring and winter they are said seldom to drink, finding sufficient moisture in the dew of the grass.

Whenever they have the chance they will venture out 
of the forest to luxuriate on the settler's corn, turnips, pease, and even potatoes; but as they generally select the night-time for these marauding expeditions, it is only when the moon shines that they can be detected, and even then it is frequently necessary to watch for many hours for that purpose. Except, however, in India or South Africa, I know no pleasanter climate for such an occupation; the summer nights are delightful, and so dry is the atmosphere that one may sit out in the lightest costume, enjoying the sweet chirping whistle of the piping-frog, which rings soothingly in the still air, while fire-flies glance in every thicket.

The "salt licks" met with in many parts of the country are also a favourite resort of the Deer, and if any at all are about the neighbourhood they are sure to be found there, and are consequently watched for and killed by shooters stationed beforehand in the nearest trees.

A mode of destruction, less common in Canada than in the States, is practised on dark summer nights as follows. A blazing light of birch bark and "fat pine" is kindled in an iron cresset fixed in the bows of a canoe, precisely as in salmon spearing; the rifleman sits amidships, covered by green boughs, and the steersman similarly concealed, gently paddles the little skiff along the dark wooded shores of the lake or river, at the hour when the Deer, after the heat of the day, repair to the 
cool waters. As the strange light glides noiselessly towards them they stand transfixed and apparently fascinated by the glare, until its reflection in their glittering eyeballs discovers their position to the concealed marksman, who, at close quarters, fires between the two with deadly effect.

Among the Yankees it is usual, I believe, for the shooter to carry the blazing fire in a pan with a long handle over his left shoulder, and in this manner to move stealthily on, with his rifle at the "ready," the handle of the fire-pan serving at the moment of taking aim as a rest for the barrel! It appears a somewhat awkward performance, and loading must be attended with even greater inconvenience, while there is little to be said for the sport, if indeed it deserves such a name. A somewhat similar plan is, I believe, practised by the natives in Ceylon. Sometimes a fire is lighted on the ground, and the shooter, concealing himself behind the trunk of some neighbouring tree or bush, lies in wait for the deer, which the strange light is sure to attract.

A method much resorted to by those who do not appreciate the superior attractions of the more noble art of stalking, is that of "driving," which, as practised in Canada, only differs from roe shooting in Scotland in the fact that the "guns" are not stationary. After they 
have been posted at the different points or runs, where the deer are likely to break cover or give the chance of a shot, the dogs and drivers enter the forest at a distant point, and the intervening tract is hunted with loud halloos and the barking and yelping of the motley pack: These dogs, however, are not taught to keep together on one deer, but are allowed, or rather encouraged, to chase different animals, a part of the pack following the original or first viewed one, while the rest in twos or threes are hunting others. These fly in different directions simultaneously, with the hounds in full cry, and the guns make with all speed for the points they are likely to cross. The regular backwoodsman rarely adopts this practice, for he seldom fires at a deer unless it is stationary, and never attempts very long shots.

The only really sportsman-like way of deer-killing is "still-hunting" or stalking, which in the forest is similar of course in all its details to the stalking of either moose or caribou, and may be followed equally in autumn or winter, the proper season being from the 1st of September to the 31st of January. In the former period the months of September and October are the best, and at that time the Deer are also more abundant, being driven to the lakes and rivers as a refuge from the swarms of flies which still infest the up-country forest. In stalking it is 
to be borne in mind that Deer, when disturbed, invariably move up-wind; when, therefore, a herd is discovered a rifle should be posted at the point they are likely to make for, while another, taking a wide circuit, gradually and cautiously steals round; till the herd gets a slight sniff of him from a distance great enough not to alarm them, and yet sufficient to cause them to move off gradually towards the concealed rifle, upon whom, at the right moment, a more rapid advance or a shot will drive them with the greatest certainty.

In winter stalking, the time generally chosen is rather early in the season, before the snow has accumulated to any great depth. The Deer are then compelled again to seek the forest, not merely for protection from the biting blast and sweeping drift, but because the sheltered surface, being less deeply covered with snow, affords more chance of obtaining food.

Their presence at this time in any particular locality is ascertained at once by their tracks in the snow, the discovery of which immediately puts all the hunters of the neighbourhood on the qui vive. This is, in short, the season par excellence for deer-stalking.

In the Canadian winter ice and snow assume the most attractive and enjoyable aspects they are capable of, and without our tedious prelude of cold and broken weather the season comes all at once. The glowing 
autumn woods rain down their shower of bright, and many-coloured leaves, mingled sometimes with the falling snow-flakes, and in an incredibly short time the forest stands cold and bare on the whitened plain.

As the fall continues, the snow-drift gathers high against the double-glazed windows, and enormous fires of huge logs are piled in the wide open hearths. But after a few days of storm the sun shines out again from a cloudless sky of the deepest blue, though without thawing even the smallest twigs of the frosted trees; and the white expanse of country, broken only by snow-laden masses of dark pine, glitters to the horizon.

All the rivers are frozen over; even the broad and rapid St. Lawrence is arrested in its course,

"Flumina constiterint acuto;"

and like the streets is covered with horses, and sleighs arrayed in rich furs, and with figures dressed in blanket coats, red sashes, and moccasins. The wonderful and glorious sunsets of this season cannot fail to strike the inhabitants of our dull clime with astonishment. The period associated in our minds with dreary afternoons and leaden clouds, is here a constant succession of gorgeous evening skies, suffusing the snow-fields with a rosy tinge.

The moon, too, shines with a brilliancy, and the stars, 
doubled in apparent magnitude, flash with tints unknown in skies less clear; while the aurora shoots nightly across the heavens in ever-changing rays of prismatic hue.

On the great lakes, however, fogs of Newfoundland intensity are not unfrequent. The larger lakes never freeze over for any distance from shore, but Erie, being much shallower, is frequently covered with ice to a very considerable extent. Every storm of wind breaks it up again, and carries it over the Niagara Falls; thus covering the surface of the lower lake (Ontario) for miles ont with white and glistering floes, causing an extraordinary depression of temperature.

On two different winters, I have seen this broken ice come over the Falls in such quantities as completely to block up the river below the cataract, forming a solid mass of enormous blocks extending from bank to bank, enabling us to approach to the very foot of the Great Horseshoe.

Notwithstanding the low range of the thermometer, $25^{\circ}$ below zero (Fahrenheit) being a common state of things, the extraordinary degree of cold that really exists is not felt to anything like the extent that might be anticipated. In fact, excepting in the case of wind, which produces a painful burning sensation, I never suffered more inconvenience from it than I have often done in many of our own winters, though huge trees 
are frequently riven by the frost-echoing through the woods with thundering reverberations, - and a rifle barrel incautiously grasped with the naked hand will adhere to it like red.hot iron.

The raw sloppy weather, the half-melted heaps of dirty snow in shady corners; the mud and slush, and dripping trees, characteristic of the British winter, are almost unknown miseries. From month to month the snow rests pure and bright as on the day it fell, the azure sky is without a cloud, and the weather is often so indescribably clear and brilliant, and the atmosphere so exhilarating; as to impel one to almost boisterous mirth. It is probably this that makes the winter so pre-eminently the season of gaiety and enjoyment.

Braced with renewed energy the deer-stalker packs his sleigh and prepares for work, preferring the keen air and invigorating excrcise of the winter "tracking" to the relaxing heat and the clouds of musquitoes which are the accompaniments of autumn hunting.

His ammunition and creature comforts being stowed away, and the warm sleigh-robes duly arranged, the snorting horses, with tinkling bells and gay "streamers," speed along the crisp and shining track, bound for the distant deer-forest. Away along the silent roads, that stretch through dark pine woods-away over open clearings-through acres of blackened stumps-past solitary 
log-huts or groups of wooden houses-skirting miles of high snake-fence, or of dark river covered with crashing blocks of ice-they fly along, never relaxing their pace except to pass some heavy-laden wood-sledge.

This manœuvre, by the way, when the road is only wide enough for a single sleigh (invariably the case at any distance from a town), is not so simple a matter as it may appear, neither party being willing to yield an inch more of the hard-beaten track than he can help doing, well knowing that if he get one "runner" in the soft snow on either side he must of necessity be capsized. These large rough sledges, heavily loaded with firewood -an article not easily spoiled-occupy, on these occasions, much the same position in relation to a private sleigh that a heavily-loaded waggon would to a small pony-phaeton ; that is to say, they have it all their own way, and when the driver is a recently arrived Irish emigrant he generally avails himself of the advantage, with an open rudeness which is in pitiable contrast to the manly good-humour of the Canadian or the ready assistance of the grinning negro.

After sunset the temperature sinks rapidly, icicles hang from the horses' nostrils, and the breath freezes on the beard or blanket-coat, as the north wind whistles through the leafless forest, sweeping the drift in clouds across the country. At night-fall a desolate wooden inn 
is hailed with delight as their halting place: a solitary divelling; half-buried in snow, at the edge of an endless forest, and miles away from any other habitation.

At early morn, clothed in a blanket suit, and armed with knife and rifle, the hunter is on his way to the forest, accompanied by some squatter or half-breed guide. A slight fall of snow having taken place during the - night is a subject of mutual congratulation, for the crunching of a frozen surface is obviously a serious drawback to still-hunting, besides which, the freshly sprinkled surface renders the trail more easy to follow.

After making a detour, more or less extended, in order to get an up-wind beat, they hit fresh trail, and after a careful reconnoissance proceed with redoubled caution. Shortly the appearance of moving objects causes them to crouch suddenly behind the nearest tree, and after a whispered consultation one creeps stealthily round towards a point for which the Deer are likely to make, while the other is left to approach them with all the skill and address he is possessed of.

After carefully noting the next point of cover for an advance, he commences cautiously to glide from tree to stump, and from stump to bush, watching with breathless anxiety, at each point gained, the movements of the herd before him. A noble buck with branching antlers drops behind his companions, to enjoy the luxury 
of rubbing his neck against a tree - an occupation apparently so agreeable and engrossing that the stalker steals a hundred yards nearer without giving any alarm. Though there is not a moment to lose, and silence and circumspection are momentarily more necessary, he is still too far off to hazard a shot, and to increase the difficulty, he has probably got into such a labyrinth of rotten sticks and fallen trees, that the possibility of getting nearer without discovery seems hopeless.

Strange as it may appear, it is not on the eye or head of the feeding deer that the steady gaze of the stalker is fixed, but on its tail. If that is jerked with a quick nervous shake, he crouches lower, warned that the animal is about to raise its head. If after a short gaze round, it again twitches the tail, he prepares to move on, knowing the animal will return to its food. Then seizing the opportunity, with one or two swift and silent strides, he is safely behind a giant trunk, within easier range of his object. But though he has not made the slightest appreciable noise, and the little wind moving is in his favour, so acute are the deer's senses of smell and hearing that it suddenly lifts its head erect, and sniffing the air suspiciously, begins to move off-

Simultaneously with the sudden crack of the rifle it gives a convulsive leap, and, throwing up clouds of 
snow at every stride, bounds away at headlong speed. If the tail is down-always a sign that the wound is mortal-the blood-stained tracks are followed up with all haste, and more than likely with many a fall over the stumps and trunks of snow-hidden trees; a chase which, according to the nature of the wound, and the age and "strength of the animal, may either be very short, or "so protracted that the hunter may consider the loss of his prize a minor consideration in comparison with the chance of losing himself in the forest. Sooner or later, however, he will find it, either stone dead or stretched before him in its last struggles. Let him not approach incautiously in the latter case, or he may chance to receive a kick that will lay him up for days: a fact which personal experience gives me cause to remember.

The Indian's usual method of temporarily securing the carcase is by attaching it to the top of a young tree, which, by climbing, he has bent to the ground, this being let go, springs back with its lighter load to its upright position, the flesh safe, not only from prowling wolves, but even from the tree-climbing bear, which has a mortal antipathy to venture up anything unequal to its weight. The Canada-jay, however, will not fail to attack the flesh at the earliest opportunity.

The backwoodsman, to whom the difficulty of obtain- 
ing supplies is a matter of consideration, considers the recovery of his bullets a point of such importance that he invariably cuts them out of the carcase, to be remelted in his wooden ladle for future service.

Valuable as are skins of the Moose and Caribou, those of the Deer are still more esteemed on account of their greater softness and pliability, as well as their property of better resisting injury from wet.

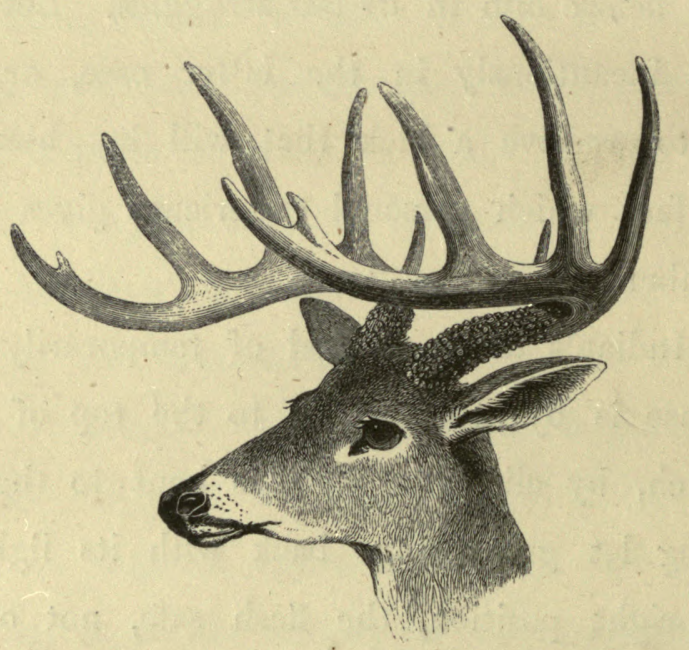




\section{DIVISION II.}

\section{ßitros.}





\section{CHAPTER V.}

\section{新ixos.}

SILENCE OF THE FORESTS - INTERESTING BIRDS-WHITE-HEADED EAGLEVARIETY OF HAWKS-MUSQUITO HAWK-OWLS-GREAT HORNED OWL -SNOWY OWL-ABSENCE OF BIRDS IN WINTER-SNOW-BIRDS-ESTEEMED A DELICACY-THEIR RESEMBLANCE TO ORTOLAN-FAMILIAR ENGLISH BIRDS-CHARACTERISTICS OF COUNTRY-THE FORESTABSENCE OF THE COMMON SPARROW-PRINCIPAL FEATHERED INHABITANTS OF THE FOREST-GAME BIRDS OF THE COVERTS AND PLAINS-WADERS AND WATER-FOWL-GAME-SEASONS OF THE UPPER AND LOWER PROVINCES-THEIR DISCREPANCY-ITS EFFECTS-PROPOSED ALTERATION. 



\section{CHAPTER V.}

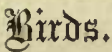

THOUGH one might not unnaturally imagine that

1 birds of every kind would enliven the vast tracts of wood clothing the face of the country, the Canadian forest slumbers in everlasting and almost oppressive silence; and even beyond its precincts the general impression produced on my own mind was rather that of the deficiency than the number and variety, of the feathered tribes, as compared with those of Great Britain and other parts of the world; though some of the species and varieties were both new and interesting.

Few sights of the kind can well be more so, than that of the great-whiteheaded-eagle* on the wing: a spectacle I had the gratification of witnessing in the neighbourhood of the Falls. It was a bright sunny morning when we suddenly descried it floating almost overhead, with an immense expanse of wing, and apparently suspended motionless in the air. As we stood and watched

* Haliotus leucocephalus. 
in admiration, it ascended, without any perceptible motion of the wings and in a series of circular sweeps, higher and higher, till it dwindled to a mere speck, and finally disappeared in the deep blue above.

I was fortunate also in twice seeing during an unusually hot summer the somewhat rare swallow-tail or musquito-hawk, , in the neighbourhood of St. Davids, soaring in pursuit of insects, and performing the most singular and graceful evolutions. It has a most beautiful black and white plumage, with very elegant form, and is not often seen in such high latitudes, boing peculiar to the Southern States.

There are a number of hawks of the more ordinary kinds, most of which are either similar to or varieties of those common to own country: as the peregrine, goshawk, and merlin; and there would be no difficulty in training them for the purposes of hawking: a sport for the pursuit of which the cultivated parts of the country are admirably adapted.

Owls of different kinds inhabit nearly every wood, waking the echoes at night, with loud unearthly cries and melancholy hootings, startling alike the settler in his lonely hut, the hunter at his fire, and the belated traveller who hurries along the gloomy forest track. 
Those who have only heard the cries of the English owls can have no conception of the loud and startling calls of some of these enormous birds. The greathorned-owl,* which is nearly two feet high, is perhaps the most remarkable in this respect of all its tribe; but though often heard it is seldom to be seen, passing the day, as it does, in the impenetrable coverts of the swamps. Of the snowy-owl, $\uparrow$ I had the fortune to inspect closely a splendid specimen, a female, fully two feet in height, which, perched in a lofty hickory, was fired at and brought down by a brother-officer with whom I was out shooting. Softly, and without a rustle, it descended like a parachute to the ground, where it hopped on a $\log$, and sat staring at us with its great round yellow eyes in the utmost astonishment, making no attempt to escape, but hissing loudly when approached. It did not appear to be wounded, and was evidently more surprised than hurt, for it soon after flew off as noiselessly as it had alighted. The greater part of the plumage was white, beautifully marked with light brown spots or half moons, and it was literally a mass of the softest down. The cry of the snowy-owl is most hoarse and dismal, and has been well compared to that of a fullgrown man calling in distress for assistance. 
Few birds are to be seen in Canada during the winter months except an occasional flock of Snow-buntings,* flitting through the air with a jerking flight or running cheeping on the snow. Somewhat larger than a lark, with the upper plumage of a light variegated brown and the under pure white, these birds are very fat, and the flesh strongly resembles that of the ortolan of Southern Europe, for which reason they are much sought after, and are sold in the markets as an article of luxury.

Though grouse may be found in the spruce districts by those who will take the trouble to follow them up at this season, and in some districts a stray covey of "quail" is at times to be seen huddled together on the snow, all the wild-fowl, and the smaller birds which at other seasons give an appearance of life to nature, are absent in the more genial regions of the Southern States, and the woods and waters remain silent and deserted till the return of spring.

When the ice and snow, rapidly breaking up, convert the whole country into a quagmire, when plants and trees which for weeks past have been slowly vegetating under their snowy garb, begin to bud with incredible rapidity, and the air suddenly swarms with insect life, 
then the familiar blue-bird,* the looked-for and welcomed harbinger of spring, first of all the feathered tribes appears upon the scene.

In succession arrive the scarlet war-bird, $\uparrow$ its gorgeous hues glancing among the green leaves of the forest; the orange oriolef displaying its rich black and gold as it flies from tree to tree, and ruby-throated humming-birds§ flitting hither and thither and hovering among the flowers. Not the least interesting of the summer visitors is the cat-bird, $\|$ which is constantly to be heard imitating with extraordinary exactness the mewing of the cat, and performing other singular counterfeits, as well as the notes of most of the ordinary birds of the country. Time after time I endeavoured to get a sight of one of these birds which daily took up its position among the highest branches of a lofty tulip-tree near my quarters, but I never succeeded in obtaining more than an unsatisfactory glimpse of a slate-coloured bird about the size of a thrush, to which family it belongs.

In. strange contrast with these bright and novel plumages appear the homely chaffinch, jay, and yellowhammer, with many other old friends: a mingling of objects familiar and foreign, that here meets the eye in

\footnotetext{
* Silvia sialis. + Tanagra rubra. $\S$ Trochilus colubris. 
every direction. Side by side, for example, with oak, ash, and elm, stand gigantic hickories, sugar-maples, and butter-nut trees; ${ }^{*}$ while fire-flies and rattlesnakes inhabit the same woods with the common squirrel and the hedgehog of one's boyish hunts. Fields of common oats alternate with those of towering maize and rows of huge orange pumpkins, hoed and tended by negroes and negresses; and the roadside is bordered by peach orchards, their ripe fruit weighing down the trees, and covering the ground.

The grand forests, free of all brushwood, present a more striking appearance than anything else to the eye of one just arrived from the Old World. No one can enter their shadows or tread their long-drawn vistas of tall grey stems, spanned by over-arching roof of dark leaves, without the idea of a vast cathedral involuntarily rising in the mind. Like ruined columns, huge prostrate trunks lie strewn around, some but newly fallen, others moss-grown and verdant, with creeping plants; while many show only a dark line of decayed vegetable mould, the last and rapidly disappearing vestige of their former stateliness. Here the ground is blue with hyacinths, there covered with beds of dry leaves, the resort of snakes, blind-worms, and huge centi- 
pedes; or clothed with green turf is thickly sprinkled with the pale orchis, or thickly with the broad-leaved May-apple.*

The silence of the forest is broken only, and rendered even more striking, by the occasional loud tapping of some busy woodpecker, of which industrious birds there are an extraordinary variety. I have preserved specimens of several of the most interesting among them: viz., the yellow-winged woodpecker, $\uparrow$ which is the largest of the family, and is the workman by whom are so neatly drilled the large round holes, so often seen placed close together high up in the trunks of old trees; also the black and white woodpecker, the grey, the "hairy," and the diminutive downy woodpecker, with its crimson crown and breast of primrose.

Emerging suddenly from the cool and solemn forest shades on some sunny clearing, echoing with the shrill chirp of locusts and fragrant with the sweet-scented vine, gorgeous butterflies are seen sailing from plant to plant, and flocks of the red-winged starling, or Field

* Podophyllum peltatum. This is a delicious and refreshing wild fruit, of a deep yellow colour, and about the size of a bantam's egg, somewhat similar in appearance to the loquat. When stripped of its outer skin it presents a mass of juicy pulp and seeds, not unlike pine-apple in flavour. The plant is of low growth, and has deeply indented broad leaves and a simple white blossom.

+ Picus auratus. 
officer,* with jetty plumage and flashing epaulets of red and yellow, chatter round the marshy pools. Or a few steps from the sylvan gloom probably bring one to the bright shore of some lake, where the rippling waves murmur with refreshing sound on the sandy beach. Many a mid-day siesta have I thus enjoyed, and whiled away many a happy hour on the shores of Erie and of Ontario, gazing with untiring delight on the calm blue surface of the water, dotted here and there with a lazy sail, and mingling the heated haze of its distant horizon with the cloudless summer sky.

A peculiarity of these lake shores is the great number of Sandpipers, and the large proportion of Ravens that are at times to be seen there-the former running along the beach in large flocks, and the latter, after every storm or breeze, busily picking among the weeds and rubbish, or devouring the dead fish cast up by the waters; crows being comparatively rare birds. The Canadian crow, by the way, is smaller than ours, and has a different note.

It is not necessary, however, to enlarge upon the general ornithology of Canada; but before passing on to the more important divisions of it which the present work professes to describe, it may not be out of place to 
mention the curious fact that, notwithstanding the presence of so many of our common birds in Canada, the ubiquitous sparrow is unknown there. I have encountered its familiar plumage in Egypt and at the Cape, and abundantly in Madras, Malabar, and Bombay, where hardly any other British birds are known, yet in Canada where so many abound, it is entirely absent.

Of all the feathered inhabitants of the forest there are but three of any importance; but these belong to the highest class of game-birds, namely, the Wild-Turkey, the Spotted-Grouse, and the Ruffed-Grouse.

The beautiful and game little Colin is abundant in the thickets and broken ground of the Upper Province; Woodcock and Snipe swarm in the young woods and swampy coverts throughout the country; myriads of wild-fowl, such as can be seen in few other lands, cover the face of the broad lakes and noble rivers; and the Prairie-Hen, though not properly belonging to the garne-birds of Canada, ranges the vast plains north and south of its frontiers, within a distance so easy of access, that to omit it would be to ignore a sport which few real lovers of shooting leave Canada without having indulged in.

The singular discrepancy that has hitherto existed between the two Provinces of Canada, as to the seasons 
in which it is allowed by law to kill game, is a subject which has fortunately been noticed and reported upon by the Natural History Society of Montreal within the last few months; so that it is probable that, as far as regards some of the most important game-birds, there may ere long be a uniform law for the whole country, and one more in accordance with their habits.

The above-mentioned Society's Report justly remarks that there is not so great a diversity of climate between East and West Canada as to require separate legislation, and that the temperature differs less probably than that of different parts of Great Britain, e.g., Devonshire and Sutherland, for which there is but one law; yet in some cases game may be killed in Upper Canada, twenty miles eastward of the boundary of Lower Canada, twenty days earlier than in the latter province. In other words, the eastern boundary of the Western Province overlaps the western boundary of the Eastern; therefore a bird which flies across from the one to the other after the 1st of August loses all claim to protection, though by remaining where it was it would have been safe for three weeks longer.

A uniformity of seasons and dates is the more necessary in a country where the game is not preserved for the exclusive right of any one, and where even the law of trespass is ill-defined as regards marshes, in which a great part of the game is to be found. 
The case of wild ducks is one of the most glaring instances of shooting out of season; for by the present law they may be killed until the 30th of May, which with many varieties is the period of incubation, while there are probably few that have not then commenced to lay.

Wild-turkey and Grouse ought, in short, to be protected from the 1st of February to the 1st of September, and Wild ducks and Ptarmigan from the 1st of March to the 1st of September, which would allow them proper time to rear their young.

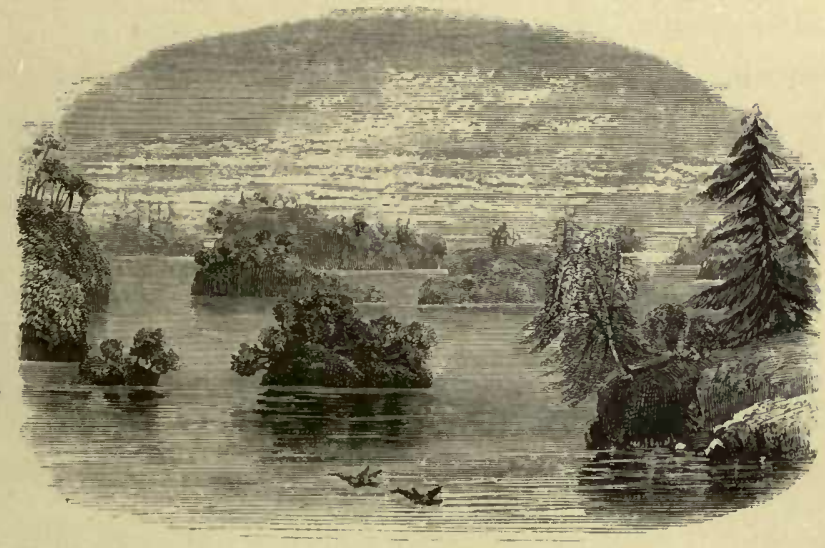

THE THOUSAND ISLES. 



\title{
CHAPTER VI.
}

\author{
dixsores.
}

THE PASSENGER PIGEON-ITS PERIODICAL YLIGIITS-BREEDING PLACESTHE WILD-TURKEY-PROBABLE PARENT OF DOMESTIC BIRD-IMPORTATION INTO SPAIN-EARLY ACCOUNTS OF-MISNOMERS-MEXICAN ORIGIN-DIFFERENCES BETWEEN WILD AND FARM-YARD BIRDS-NEST AND EGGS-CRAFTINESS OF THE HEN-YOUNG BIRDS-ASSOCIATION OF "GOBBLERS"-FOOD OF WILD-TURKEY-THEIR WANDERINGSFORMER ABUNDANCE-PRESENT HAUNTS-DIFFICULTY OF APPROACHING THEM-SEASON FOR HUNTING-THEIR GAME QUALITIES-GRADUAL EXTERMINATION-THE GROUSE OF CANADA-THE SPOTTED-GROUSEPLUMAGE AND HABITS-FEMALE-THEIR SIZE-THE PRAIRIE-HENWEIGHT AND PLUMAGE-SINGULAR CALL-FEMALE BIRD-PUGNACITY OF MALE BIRDS-BREEDING SEASON-EGGS-YOUNG BIRDSSEASON FOR PRAIRIE-HEN SHOOTING-DOGS FOR-SIZE OF COVEYS -FOOD OF PRAIRIE-HEN-WINTER HABITS-QUESTIONABLE ADVANTAGES OF ACCLIMATISING - THE PTARMIGAN - PLUMAGE IN SUMMER AND WINTER-WHERE FOUND-EGGS-THE RUFFED-GROUSE - HABITAT-ITS SIZE AND APPEARANCE- "DRUMMING"-MANNER OF WALKING-FLIGHT-SHOOTING SEASON-UNFIT FOR FOOD IN WINTER -THE COLIN-ITS HAUNTS-CALL NOTE-SEASON FOR SHOOTING -iNTRODUCTION INTO ENGLAND. 



\section{CHAPTER VI.}

\section{Columbax; Gallimx.}

W HILE quartered at Fort Mississisaugua (Anglicè, Rattlesnake), an old frontier post of earthwork and palisades, near Niagara, I had one year, in the month of May, the gratitication of witnessing a spectacle I had frequently heard of-namely, a grand migration of the Passenger Pigeon (Ectopistes migratoria).

Early in the morning I was apprised by my servant that an extraordinary flock of birds was passing over, such as he had never seen before. Hurrying out and ascending the grassy ramparts, I was perfectly amazed to behold the air filled and the sun obscured by millions of pigeons, not hovering about, but darting onwards in a straight line with arrowy flight, in a vast mass a mile or more in breadth, and stretching before and behind as far as the eye could reach.

Swiftly and steadily the column passed over with a rushing sound, and for hours continued in undiminished 
myriads advancing over the American forests in the eastern horizon, as the myriads that had passed were lost in the western sky.

It was late in the afternoon before any decrease in the mass was perceptible, but they became gradually less dense as the day drew to a close. At sunset the detached flocks bringing up the rear began to settle in the forest on the Lake-road, and in such numbers as to break down branches from the trees.

The duration of this flight being about fourteen hours, viz., from four A.M. to six P.M., the column (allowing a probable velocity of sixty miles an hour, as assumed by Wilson), could not have been less than three hundred miles in length, with an average breadth, as before stated, of one mile.

During the following day and for several days afterwards, they still continued flying over in immense though greatly diminished numbers, broken up into flocks and keeping much lower, possibly being weaker or younger birds. As they were now within easy shot, sometimes flying so low as to be brought down even by sticks and stones, every one fortunate enough to own anything in the shape of fire-arms turned out with it, whether musket, flint-lock, Yankee rifle, or blunderbuss. For several weeks afterwards, small flocks remained behind in the woods, affording more real 
sport than the above wholesale slaughter, though we had had quan. suff. of pigeon diet.

During these flights parties carrying lanterns and torches often repair at nightfall to the woods, armed with guns and long poles. The ruddy light cast up into the dark trees reveals thousands of dazzled stupified pigeons, weighing down the branches high and low. In a moment the long poles are rattling among the lower boughs and the guns blazing away at the higher, bringing down the birds by hundreds, fluttering on the ground and showering on the heads of the clamorous crowd that scrambles and scuffles beneath.

The Passenger Pigeon differs a good deal from the common wild pigeon of Great Britain; its appearance when flying more resembling that of the sparrow-hawk, in the sharp pointed wings and long narrow tail. The plumage is of a somewhat bluish ash colour; the breast and sides being of a rich chocolate; the neck and throat tinted with iridescent green and purple.

Though these flocks, in greater or less number, pass over the country every summer, they are not of course always seen in the same districts. The time of their appearance also varies considerably, depending as it does on the scarcity of food in the regions they have left.

It is not the case, as stated by Wilson and other naturalists, that the female lays and hatches only a single 
egg at a time, for there are generally two birds in each nest, which are also said to be male and female; but even with this increased proportion of young their numbers appear extraordinary, when it is remembered that they have as many enemies to contend with as the quail, which has a nest of twenty eggs, or the wild-turkey, with a brood of fifteen, both which birds are rather on the decrease than otherwise. Wilson, ${ }^{*}$ who describes some of the breeding places in the States as being forty miles in extent, with every tree killed, the ground covered deep with their dung, and all grass and underwood destroyed, says, "As soon as the young birds are fully grown, and before they leave the nests, numerous parties of the inhabitants from all parts of the adjacent country come with waggons, axes, beds, and cooking utensils, many of them accompanied by the greater part of their families, and encamp for several days at these immense nurseries. The noise in the woods-i.e., from the pigeons-is so great as to terrify their horses, and it is difficult for one person to hear another speak without bawling in his ear. The ground is strewed with broken limbs of trees, eggs, and young squab pigeons precipitated from above, and on which herds of hogs fatten. Hawks, buzzards, and eagles sail 
about in great numbers, and seize the squabs from their nests at pleasure, while, from twenty feet upwards to the tops of the trees, the view through the woods presents a perpetual tumult of crowding and fluttering multitudes of pigeons, the sound of their wings roaring like thunder, and mingled with the frequent crash of falling timber; for now the axe-men are at work, cutting down those trees that seem to be most crowded with nests, and contriving to fell them in such a manner that in their descent they might bring down several others, by which means the falling of one large tree sometimes produces two hundred squabs, little inferior in size to the old ones, and almost one mass of fat; on some trees upwards of one hundred nests are found. It is dangerous to walk under these flying and fluttering miliions, from the frequent fall of large branches, broken down by the weight of the multitudes above, and which in their descent often destroy numbers of the birds themselves."

The Wild Turkey of North America (Meleagris gallopavo) is without doubt the parent stock from which the domestic breed of our farmyards is originally descended, notwithstanding the existing differences between the two birds at the present day, and the scepticism that prevails among so many on the point.

It does not appear unreasonable to suppose that thesc 
differences may have been brought about in the course of generations by the change in food and climate, and by the influences of confinement and domestication to which the common turkey has been subjected, and I shall show how little data there is to go upon in assuming any other country than North America to be the native place of its ancestors.

From Bonaparte's account we learn that it had been introduced into Spain only a very short time previously to its appearance in England, which was about 1520 to 1524, having been taken thither by the Spaniards from Mexico, about the time of the conquest of that country, and by them named Pavon des las Indias.

This appellation was evidently bestowed under the impression that Mexico had originally been indebted to the West Indies for the possession of this valued and even then domesticated bird: an assumption which is countenanced at the expense of his own country by Baird, the celebrated naturalist and latest writer on American ornithology, who meets the fact of there being no wild turkeys in any of those islands at the present day, by the supposition of their gradual extinction, as in the case of the dodo.

We learn however from Prescott* that Oviedo (Rel. 
Sumaria, cap. 38), the earliest naturalist who gives any account of the bird, mentions having seen it in the West Indies, "whither. it had been brought from New Spain." The former author further states, quoting from Buffon,* that "the Spaniards saw immense numbers ' of turkeys in the domesticated state on their arrival in Mexico, where they were more common than any other poultry; and that they were also found wild, not only in New Spain, but all along the continent in the less frequented places, from the North-Western territory of the United States to Panama." And again, in the interesting relation of the advance of Cortes to Cempoalla, he says that "Deer and various wild animals were seen, with which the Spaniards were unacquainted; also pheasants and other birds, among them the Wildturkey, the pride of the American forest, which the Spaniards described as a species of peacock."

Their abundance is evident from a fact which I find mentioned in an old book, called "Gay's Survey of the West Indies and Mexico," published in 1702, namely, that in Montezuma's menagerie, the animals were "fed daily with turkey cocks, deere, dogs, and such like; one house having for daily allowance five hundred turkeys." Nor were they by any means confined to this southern 
portion of the continent. Ogilby, in his curious work on America, dated 1671, quoting Hudson, the celebrated North American explorer, remarks, that not only in Maryland and Carolina were these birds common, but even as far north as the State of New York; speaking of which, he says, "the country abounds chiefly in turkeys, whose plenty deserves no less admiration than their bulk, and the delicious taste of their flesh; for they go feeding forty or fifty in a flocke, and weigh sometimes forty or fifty pounds apiece. The natives either shoot them, or take them with a bait stuck on an angle."

From the above evidence it will therefore be seen, that while we have accounts of their existence at an early date in great abundance over a very large area of the continent of North America, the earliest record we have of their existence in the West Indies, specially mentions the fact of their having been brought thither from the main land.

The slight value to be attached to mere local names is well exemplified in our own misnomer, "Turkey," which we have absurdly bestowed on this bird for no better reason than that at the time of its introduction into England most foreign articles were vulgarly supposed to come from that country; while the French dindon, which is a corrupted abbreviation of coq d'Inde; the Italian gallo d'India, and the German Calecutische Hahn, 
assign it to the Old World instead of the New, apparently from a confusion of the East Indies with the West.

There is, I think, in short, no doubt whatever that long before the landing of the Spaniards in Mexico, the natives, who are to this day in the habit of trapping the bird alive in great numbers, had been accustomed to bring them for sale from the interior to the coast, and that the name pavon de las Indias was ignorantly bestowed on them by the sailors or soldiers to whom they were offered for sale; much in the same careless manner in which our own equally inapplicable designation was bestowed not long afterwards.

The rnost apparent and easily observed differences between the wild and the farmyard bird are the presence in the latter of a fleshy dewlap, extending from the under mandible to the neck; the bare wrinkled skin of its head and neck is much less blue, and is sprinkled with a smaller number of hairs; and the tip of its tail and the edges of the tail-coverts are generally white or whitish, but never so in the one of which we are treating. There is said to be a variety peculiar to Mexico, in which the white does appear at these particular points.

The care and attention of man have not in this instance improved the breed, for the fostered descendants are less hardy, and also inferior in plumage and form to 
the uncared-for tenants of the forest. About sixteen pounds is probably the average weight of the male wild bird when in good condition, and they have been shot weighing nearly double as much; but they vary greatly in this respect, according to the season, and to the abundance or scarcity of food obtainable. In the summer months they are poor and lean, and much infested with vermin, but improve rapidly when the beechmast comes in, and are in their highest perfection late in autumn. The flesh is darker in colour than in our turkey, and more game-like in flavour.

The length of the male bird is nearly four feet; its head and neck are covered with purplish-red excrescences on a naked blue skin, thickly overspread with bristles, and a tuft of horsetail-like hairs hangs from the breast, similar to that seen in the domestic bird, but larger and longer. The game-looking head is smaller than that of the latter, and the general hue of the plumage is a beautiful golden copper, with purple and green reflections, mottled and banded with a deep soft black. The lower part of the back is an iridescent brown, and the tail, which is of a darker hue, has a broad black band at a short distance from the extremity, with an outer border of dark yellowish brown.

The female, which is a much smaller bird than the male, seldom weighing more than nine pounds, is also less 
showy. Her plumage has sometimes a grey tinge, and the general colour is always less brilliant. The fleshy process on the head is much smaller, and is without bristles; she has no spur, and seldom any tuft on the breast, though in old hens this appendage is sometimes found in conjunction with a partial assumption of the male plumage; appearances which are common in many other gallinaceous birds, and may generally be traced to some abnormal state of the ovaries. The legs are red in both sexes.

Their breeding season varies a little according to the latitude, though from the beginning of March to the end of April is probably the extent of its range, and during this period the forest echoes with their calls. The note of the female sometimes brings several male birds to the spot at once, when a battle royal irnmediately ensues, the victor securing a harem of faithful followers, over whom as well as over his vanquished rivals he acts the tyrant for the rest of the season.

The hen lays her eggs, varying from ten to fifteen in number, about a month later. The nest is merely a hollow scratched in the ground, under the shelter of a bush or by the side of a fallen tree, and filled with dead leaves. The similarity of these in colour to that of her plumage is so great that she is not easily detected, even at close quarters: a circumstance of which, judging from the 
courage with which she remains on her nest when closely approached, she appears to be fully aware. She is also singularly crafty in guarding against its discovery, her devices in this respect exhibiting rather the presence of thought than of mere instinct. She never leaves it nor returns by the same approach, and always covers the eggs over with dry leaves, so as to resemble the surrounding ground, during her absence in quest of sustenance. In spite, however, of her precautions they are frequently destroyed by other birds or by the smaller animals of the forest.

It is not uncommon to find a couple of hens on the same eggs, and it is the opinion of some that they thus become partners for the sake of mutual protection: one or other in such instances being always left in charge.

The eggs differ a good deal in colour and marking; those which I have seen were rather smaller and more obtuse than the eggs of the domestic turkey, and in place of the small reddish-brown spots with which the latter are mottled, were marked with irregular blotches of a darker colour.

When the young birds are hatched, the mother leads them carefully to the driest ground in the vicinity, where she endeavours to keep them until they are sufficiently strong to wander more at large. In a very short time they are able to fly to the lower branches of the trees, on 
which they roost at night under cover of the maternal wing, and in the month of August such as have escaped the claws of the lynx and the attacks of the "old gobblers," are able to take care of themselves. Excepting in the breeding season the male and female birds, like our own pheasants, are seldom seen together, but feed in separate flocks, though not very far apart, and roost with similar unsociability on different trees.

According to Wilson's* account of this bird, "the gobblers keep. together in flocks varying from ten to a hundred, whilst the females with their young form distinct troops, remaining at a distance from the old males, which never lose a chance of attacking, and, if not driven off by a posse of females, killing the young. The same general direction of travel is observed by the troops of both sexes in their migration in search of new feeding grounds, and the journeys are always performed on foot. When their progress is interrupted by a river they will hesitate for a day or two on the banks, as if unwilling to risk so formidable an undertaking. All this time the males gobble continually, and strut about with absurd importance; the females and young also assuming much of the same pompous air. At length the moment arrives, and the whole mount to the tops of the highest trees and

* American Ornithology. 
take flight together towards the opposite bank. The older birds cross, without much difficulty, rivers even a mile in width; but the young and weak often fail to reach the other side and have to swim for it, which they do well enough. If, in the endeavour to land, they approach an inaccessible bank, they resign themselves to the stream for a few moments, in order to gather strength for one grand effort; but many of the weaker, which cannot rise sufficiently high in the air, fall again and again into the water, and are finally drowned."

The Wild-turkey subsists principally on nuts, beechmasts, acorns, wild strawberries, grapes, and dew-berries; corn, when it can be got, and grasshoppers and other insects whenever they chance to come in the way. Though properly speaking not migratory, these birds range very widely in search of food, and the common impulse to desert an exhausted country for fresh ground causes them to wander as well as to assemble together, as just described, in the flocks which are commonly met with in the month of October; but they invariably return to certain localities in which they may be said to be resident.

Though formerly abounding in every part of the country, from the Mexican Gulf to the Great lakes, the increase of population and extension of cultivated tracts have now confined them entirely to one or two districts. 
In Canada they are met with in the detached belts of wood west and north of Lake Superior, and in the forests west of Amherstburg. There are a few near Chatham, and I am told that there are scattered birds in the neighbourhood of Hamilton, at the upper end of Lake Ontario, and also in other western townships; but I never heard of them when in those parts myself and should be inclined to doubt it. It is a singular fact that they are unknown in the Eastern Province, though they still extend from western Canada through the States, as far south as Mexico.

As a sport, the pursuit of the Wild-turkey ranks high in the estimation of the sportsman. I do not of course allude to the practice of shooting the roosting birds on moonlight nights, when they guide the gunner by their continual gobbling, and sit helplessly looking at their falling companions without attempting to escape; or to the equally exciting amusement of calling the male birds in the breeding season by imitating the cry of the hen, and then riddling the unsuspecting dupe at close quarters with a charge of buck-shot. Nor is the practice of the Indians and settlers much more to be commended, who, immediately after the breeding season, when the males are in the worst possible condition-poor, lean, and reduced-hunt them on horseback, and with the assistance of their curs run them down, at a time when they 
are scarcely half their proper weight, and altogether unfit for food.

The proper season for the legitimate sport is late in the autumn, when, after a summer diet of strawberries and wild fruit, they have had a six weeks' or couple of months' run among the acorns and masts. It is then a splendid bird in every respect, and so wild and diffcult of approach as to require no inconsiderable amount of skill in stalking, and even then is not often to be reached without the rifle. A bird with these qualities, excelling, also, in point of size, beauty of plumage, and culinary qualities, may well rank among game-birds of the highest order.

The difficulty of approaching within range, however cautiously the hunter may conceal himself, has led some to suppose that the Wild-turkey is gifted with an acute sense of smell. In all birds, however, excepting those of prey, this faculty is very imperfectly developed, and I do not think there is any reason to believe that this individual one is any exception to the rule. A quick ear and keen eye, combined with great watchfulness, alone enable it so easily to detect the presence of danger; for the old birds are always on the alert even while feeding, and it requires all the caution and address of the practised stalker to steal in upon them.

The chief difficulty in finding them is the absence 
of sufficient trail to indicate their proximity, whence it happens that one may either never find a flock at all, or may come on it unawares, and frighten the birds away before there is a chance of a shot.

For this reason the half grown birds are sometimes tracked with a dog trained for the purpose, which, on striking the trail, follows it up without an instant's hesitation, and without giving tongue, till he runs right into the flock. Thus alarmed, the birds at once take to the trees, the dog sitting at the foot of the trunk barking at them, and so engrossing their attention that the guns, with a little caution, are able to get within range. The old birds, however, if thus disturbed, run so swiftly and for such extraordinary distances that few animals are able to overtake them, their pace being a sort of flying stride.

Single birds, instead of running, crouch in the grass, and lie till flushed, when they rise suddenly, and so close as to give a fair flying shot. Flocks even of twenty or thirty will occasionally rise in this manner and fly to another thicket; but this is the exception rather than the rule, and he who beats the woods in hopes of "walking up" the birds will in general drive them all away long before he comes near.

Their flight, except when pressed by some imminent danger, is generally only for short distances, the bird's 
bulk and small expanse of wing being obstacles to any lengthened journey in the air.

The Wild-turkey, though so shy, is not unfrequently found in forests within reach of cultivated ground, especially late in the year, when wild-fruit and berries have become scarce, its partiality for the settler's grain being the inducement thus to brave the neighbourhood of man. In severe winters too in the early morning, when no one is stirring, they will occasionally venture even into the farm-yards in search of corn.

Though the immigrant farmer cannot be blamed for not preserving these birds, which are at times exceedingly destructive to his crops of maize and oats, it is to be regretted that they should be wantonly killed at a season when they are useless; for by sparing them a few months he might supply his table with delicious food, and in the interim they could not eat more than the domesticated ones fattened at home. But every possible device is resorted to by the uneducated that can assist in the work of gradual extinction. The landlords of the outlying taverns catch them alive with the object of enticing customers, a number of whom pay so much a head for each shot with the rifle at an unfortunate bird, which is secured at a certain distance, close behind the trunk of a tree sufficiently large to conceal all but its head. Whole flocks are sometimes caught in a cage made 
of sticks, placed on a sloping piece of ground, with corn strewed around, and leading through a low entrance to a larger supply within; once inside, the turkeys raise their heads in alarm, and vainly attempt to escape, never stooping to look for any egress below their own height.

Though this mode of destruction is in Canada forbidden by the game-laws of the country, it is obviously impossible in wild and thinly inhabited districts to prevent the lower and more ignorant class of emigrants from imitating the customs of the free and enlightened citizens over the border, in spite of any argument to the effect that by so doing the ultimate extinction of the objects of their selfish crusade is rendered certain; and thus the gradual extermination of this noble bird proceeds slowly but surely year by year.

As a means of suppressing this slaughter, it was at one time proposed to legalize the seizure of any birds exposed for sale that did not exhibit marks of having been shot; though this requirement was easily complied with, as the poachers had only to fire a charge of shot into a whole heap of trapped birds in order to satisfy the condition.

Next in importance to the Wild-turkey are the different kinds of Grouse peculiar to North America, which are arranged by Baird in the following four Divisions :- 
1. Those having the legs feathered to and on the basal membrane of the toes; and without any ruff on the neck; which has, however, a bare extensible space.

2. Those with the legs scarcely feathered to the extreme base of the tarsus, the lower joint of which is bare, with large transverse scutellæ.

3. Those with legs feathered to the claws.

4. Those having the lower half of the tarsi bare, with two rows of scutellæ anteriorly.

Tetrao, belonging to the first division, Lagopus forming the third, and Bonasa the fourth, only frequent wooded tracts ; while Cupidonia, which forms the second, inhabits the open prairie: these four genera comprising all that come under notice in the present work.

The Canada or Spotted Grouse (Tetrao Canadensis) is better known in its own country as the "Spruce Partridge:" a glaring misnomer, which its marked characteristics render inexcusable in British provinces.

Though not a scarce bird, it does not exist in any great numbers in any part of the country, nor is it easy to find, even in those districts where it is known to be in tolerable abundance, seeking, as it does, the most tangled and difficult recesses of unfrequented spruce forests and cedar swamps.

It ranges from the confines of the Northern States to latitude $68^{\circ}$, though never found to the westward of 
the Rocky Mountains. They are common in many parts of the Eastern Province of Canada, including the Montreal and Quebec districts, and are found plentifully in the neighbourhood of Lake Matapediac, the Marcouin River, and the Magdalen River; also near Penetanguishene, and in other parts of the Upper Province.

It is a matter of congratulation to learn from the Fifth Annual Report of the Montreal Game and Fish Protection Club that this bird is increasing in numbers. According to the above report, the destruction by snaring appears to have lessened considerably of late years, and if the amendment to the bill asked for were passed, and snared game could be seized in the market, there is no doubt that the practice would soon cease, and this fine bird become exceedingly abundant.

When disturbed the Spotted Grouse runs swiftly along the ground, and does not take to the wing unless pressed; then, rising with a clucking cry, it flies only a short distance and rather heavily, generally settling in some convenient tree where it is easily approached. I have often heard Canadians and others repeat the assertion, which is also common as regards the Ruffed Grouse, that a whole covey, when treed, may be killed by merely taking the precaution to shoot those on the lower branches first; yet I have never been able to meet with any well authenticated instance of its having been done. 
There is no doubt, however, of the fact that it evinces very little fear of the gun.

In appearance this is a very handsome bird, the general colour above being a deep brown, beautifully barred with black and dark grey; the throat and head are black, with a scarlet semicircle over the eye, and a small white mark near the base of the bill, which is black and rather slender. The breast and sides are marked with large white spots, and there are a few on the tail-coverts; the tail, which consists of sixteen feathers, and is about six inches long, is black, slightly mottled with dull brown and tipped with dark orange.

The female has a greater predominance of white beneath and yellowish brown above; has little or no black on the head or upper parts, and the feathers on the legs are of a lighter colour than in the male; though she has also, contrary to a very common opinion, the same scarlet space over the eye.

They breed far north, up in the Hudson's Bay country, and return to Canada in the winter. The nest, which is formed on the ground, is most carefully concealed among branches and long grass and is rarely found, whence it is that the eggs have been so variously described by different writers. According to a paper in the "Canadian Naturalist," they appear to be "white, spotted with black and yellow." 
The food of the Canada Grouse is wild berries and the buds of different trees and bushes, and in winter spruce tops and the seeds found in the cones of the pines. The flesh, which is dark, is very like that of the common grouse, but more bitter, and in the latter season has a considerable flavour of turpentine.

This is the smallest of the three kinds of grouse inhabiting Canada, and does not exceed fifteen inches in length. Its acclimatization has been, I am told, contemplated with a view to its introduction into this country, in certain districts of which no doubt it would succeed well enough; and where there is no other game to be interfered with, might prove to be an acquisition well worth the trouble of the experiment.

The Prairie-Hen (Cupidonia Cupido), though bearing a general family resemblance to the red grouse of Britain, will be seen on comparison with it to be a much larger bird, the male measuring about nineteen inches in length, and averaging nearly three pounds avoirdupois in weight; not far from that of an ordinary cock pheasant.*

The flesh is dark, very tender, and of most excellent flavour. Individual birds often vary very much in colour, as is the case with our own grouse, which in some parts of Scotland are much lighter coloured than their

* The average weight of the Scottish grouse is $1 \frac{1}{2} \mathrm{lb}$. 
normal plumage, and in others very much darker. Generally, however, the upper plumage of the Prairie Hen is a rich brown, banded with yellowish stripes. The wings, of a grey brown, are barred with reddish yellow; a brown stripe extends from the nostril along the side of the head, and another from the lower mandible to the throat, the naked space above the eye being of a bright orange. The lower plumage is grey, tawny, and cream colour, barred and variegated with pale brown. The tail is varied with light brown and brownishyellow, marked most commonly with bars of darker brown, though some specimens have the tail of a uniform colour throughout.

The male bird has a small crest, and on either side of the neck a tuft, consisting of five long black feathers, and thirteen smaller ones of a very dark brown, striped down the centre with a warm buff. These tufts, or neck wings, conceal a wrinkled yellow membrane of bare skin, which he has the power of inflating to a considerable size, and by means of which, during the breeding season, he makes a curious hollow sound, which though not loud, may be heard nearly a mile off. Audubon, in order to prove whether these bladders were necessary to the production of the booming sound, having procured a tame bird, passed the point of a pin through each of the air cells, the consequence of which 




- was that the bird was unable to toot any more. With another tame bird he performed the same operation on only one of the cells, and next morning the bird tooted with the sound one, though not so loudly as before, but could not inflate the one that had been punctured.

Wilson* says, the call "consists of three notes of the same tone (resembling those produced by the nighthawkst in their rapid descent), each strongly accented, the last being twice as long as the others. When several birds are thus engaged the ear is unable to distinguish the regularity of these triple notes, there being, at such times, one continued drumming, which is disagreeable and perplexing from the impossibility of ascertaining from what distance or even quarter it proceeds. While uttering this, the bird lowers its head like the pigeon, and exhibits all the gesticulations of a turkey-cock. Fluttering his neck-wings, and erecting them so that their usual position is reversed and they almost meet over the head, he wheels and passes before the female, and close before his fellows, as in defiance. This drumming continues from a little before daybreak to eight or nine in the morning, when the parties separate to seek for food."

The hen, which is rather smaller than the cock, has

* American Ornithology.

+ Caprimulgus popetue. 
very much the same plumage, but is without the crest, although she has rudimentary neck-wings, covering a somewhat similar though smaller naked space on the neck; this, however, is not capable of inflation.

At all times of a pugnacious character, the male birds are especially so at the commencement of the pairing season, when they fight with one another like game-cocks, strewing the sward with their feathers, returning again and again to the charge, leaping from the ground with shrill cackling, and every feather erect with fury, those of the neck forming a ruff which completely encircles the throat. The Indians, who are inveterate pot-hunters, often set nooses or lie in ambush with their guns at these spots.

The breeding season is in April and May, and the nest, which is very rude and simple, being in fact nothing more than a rough collection of dead grass and leaves, is most carefully hidden in the thick tufts of long prairie-grass. It contains from ten to twelve or even fifteen eggs, about the size of those of the bantam, and of a very pale brown colour.

They are hatched within three weeks, and the young birds leave the nest at once. When leading her brood about, and teaching them to find for themselves the various berries, seeds, and insects which are their peculiar food, the mother, if surprised, feigns lameness, and while 
her little ones run to cover as fast as their legs can carry them, she leads the intruder in a contrary direction.

Like the red grouse, this is a stationary bird, and is only met with on the vast tracts of prairie to the north and south-west of the Upper Province.

As the mountain scenery of our Highlands forms so great a portion of the enjoyment of grouse shooting, so does the majesty of these ocean-like plains add to the fascination of Prairie-hen shooting. There is something even supernaturally impressive in their vastness, everlasting silence, and solitude, and in no other situation perhaps does man feel more strikingly what an atom he is on the face of the earth than when fairly launched on the prairie. With a glorious feeling, however, of unbounded freedom, he wanders on over the grassy surface, which, dotted with bright flowers and brighter butterflies, gently rolls in the undying breeze that ever fans the plain. Here and there is a clump of stunted trees or a patch of brushwood, but these can hardly be said to break the uniformity of the surface, for they are completely lost in the immense space and are rarely noticed at all till close at hand. Indeed, so utterly destitute of any landmark is the face of the plain that a person unused to move alone in these regions would quickly lose his way, and might wander on with a hundred miles of prairie before him, in vain search of 
the point he had started from, each moment serving only to increase his distance from it, and every weary step leading him further away from human aid, fainting with fatigue and parched with thirst. No one should venture alone for any distance on the prairie until thoroughly able to trust himself to steer his own way by the aid of the sun.

Blackened tracts are sometimes seen extending for miles on every side, marking the course of those destructive fires that so often sweep with resistless fury over the wide expanse. During these conflagrations the Prairie-hens fly before the flames in countless numbers, settling after each succeeding flight, half stupified, either on the ground or on any chance tree, till again driven on by the advancing tide of smoke and heat. Where the grass is short the fire spreads more slowly, and in a thin line easily passed through, even by a man on foot, but when the waving mass of dry vegetation stands as high as the head, the devouring flames travelling with frightful rapidity, roaring and crackling in sheets of fire, scorch and suffocate all before them. The mode of escape recommended, when far out on the prairie, is to ride off at a gallop as soon as the clouds of smoke are seen on the horizon, and after gaining a sufficient distance, to dismount and set fire to the grass in front, following down wind in its 
wake. But any one unfortunate enough under such circumstances to be surprised on foot would have little chance of escaping the suffocating fumes and stifling heat, which, almost insupportable even at the distance of half a mile, close in with fearful quickness. These conflagrations must at dark be spectacles grand beyond description; for the burning plains of South Africa (on which I have many a time gazed far into the night) are said to convey but a faint idea of their grandeur.

The season for Prairie-hen shooting commences properly speaking on the 20th of August, though a barbarous and destructive practice exists among Yankee shooters of killing the half-grown birds or "chickens" earlier, because they are easier to shoot than when stronger on the wing.

Good dogs are, as in all other shooting, of course necessary, and pointers will on some accounts be found preferable to setters. Among other advantages, they endure thirst better, or more probably experience it in a less degree, and this on the prairie is a matter of some importance, seeing that it is necessary to carry every drop of water that may be required. Audubon, who was a sportsman as well as a naturalist, prefers setters, giving as his reason that the birds do not stand so well to the former. A newly arrived dog from "the old 
country," for the first time ranging over the prairies, is generally a good deal puzzled by tortoises, rattlesnakes, and other novelties, which he points with vexatious perseverance.

A good prairie dog should stand steadily for any length of time, not only because from the extent of range it often takes some minutes to walk up to his point, but because the height of the grass frequently prevents his being seen; for this cause also a dog displaying a large proportion of white is preferable.

When flushed, the birds rise suddenly with the heavy whirr of the grouse, and not unfrequently with a loud clucking noise, skimming away in a straight line, every now and then appearing about to alight, but still sailing on. The length of these flights is extremely deceptive, owing to the vastness of the area, and to the unappreciated velocity given to the bird by its weight and strength of wing. On alighting they run very rapidly, making for some hollow or tuft, but never take to the thicket, or close bushes, appearing to prefer a clear course rather than any attempt at concealment, which might afterwards prove an embarrassment. Single birds, particularly young ones, lie so close as to be with difficulty found again, however carefully marked down or quickly followed up.

The coveys generally consist of from eight to twelve 
birds; and so abundant are they in many parts of the prairie at the beginning of the season that twenty or five-and-twenty brace a day may be easily killed to a single gun. Later in the year they are not easily approached, especially if they have been disturbed and fired at. It is at all times and seasons necessary to avoid talking, as any noise of such a nature at once alarms them; and on a still day of course the greater caution is requisite in this particular.

Splendid sport may be had in the valley of the Assineboine, or on the frontier prairies south-west of Lake Michigan, which are reached by way of Detroit. Rochelle, eighty-four miles from Chicago; on the Dixon line, is also a first-rate quarter.

The ripe corn-fields of the remote and isolated settlers living on the borders of the prairie are favourite resorts; and for one or two weeks before and after harvest large packs of these birds may there be seen feeding, morning and evening. Towards the end of October it is not uncommon to see as many as two hundred birds, or even more, thus collected together.

In summer they luxuriate on wild strawberries, "partridge-berry," insects, and larvæ of different kinds. In winter the buds of various trees and the small acorn of the dwarf oak, which grows in the "prairie scrub," form their only support, and when the snow 
lies deep on the ground they are of course unable to obtain the latter, and generally sit perched up in the leafless trees : an unusual position for a grouse!

Their usual habit is to roost in a circle on the ground, though single birds will sometimes perch on a tree, even in summer. Why is it that in the New World we see grouse, snipe, and ducks sitting on the branches of trees, to the confusion of all scientific classification?

The packs of Prairie-hen which remain unbroken at the end of the season, or others collecting together from all quarters in immense numbers, often form a sort of "yard" in the snow, squatting closely together at night, as the quail do under similar circumstances. At such times the whole of them may be easily netted at once, and it is principally in this way, I fear, that the birds now so largely sent to the English market, packed in barrels with bran, are obtained by Yankee dealers. An erroneous impression prevails among many in this country with regard to the supposed poisonous state of the flesh of the Prairie-hen at certain seasons of the year. Such, however, is not the case, as they do not feed on anything of a deleterious nature. The error has arisen from confounding this bird with another of the same family, and also North-American, namely, the Ruffed-grouse, which is noticed further on. 
Though the long continuance of severe winter weather as well as its concomitant scarcity of food must be very trying to the Prairie-hen, they survive even the most inclement seasons; and this hardiness has led to the belief that their acclimatization in this country would be comparatively easy, their stationary habits and the nature of their food seeming to favour the idea. But the continual recurrence of the cold winds, rain, and fogs, characteristic of English weather, would probably be less likely to be endured with impunity than the sharp frosty air with a bright sun which is the normal state of the Canadian winter. There are also few districts suitable to its habits, for as the Prairiehen always avoids high grounds and hilly tracts, and is exclusively a denizen of the driest plains, our Scottish moors and mountains are necessarily excluded.

Supposing these difficulties overcome, the advisability of turning out these birds in our country appears questionable, for from their pugnacious habits and superior size, as compared with the red-grouse, there would be a great risk of their driving off the latter; in the same way that the red-legged French partridge has done the infinitely superior one of our own country wherever it has been introduced. And the loss or diminution of the British grouse would be but ill compensated for by the most 
complete establishment of the Prairie-hen, with all its good qualities.

The Ptarmigan, Willow-grouse, or White-grouse (Lagopus albus) is mentioned by Dr. Hall* as one of the birds of the Montreal district, though its general range is in rather higher regions, its northern limit being about latitude $70^{\circ}$.

The male bird weighs on an average about two pounds, and its plumage in summer is a reddish grey on the upper parts, closely marked with zig-zag lines. On the breast and sides are a great number of black feathers waved with a light reddish colour, and the under parts, breast and wings, together with the feet, are pure white. The male has a black mark or stripe crossing the eye, and a scarlet cicatrice over it. The female has neither of the latter distinctions.

The winter plumage is perfectly white, with the exception of the tail; this is chiefly black, and there are one or two brown feathers in the wings.

The female lays from eight to twelve eggs, and sometimes more; they are of a yellowish colour, marked with dark brown spots.

The Ptarmigan lives in winter on the buds, seeds, and young tops of the willow, whence its other name of Willow-grouse.

* Can. Nat. Geo., Montreal. 
The Ruffed-grouse (Bonasa umbellus) in point of size occupies a middle place between the Prairie-hen and the Canada-grouse, and like the latter resides entirely in thick coverts. There is, however, this difference between the habits of the two shade-seeking birds: that while the one, as already described, inhabits only the low-ground forests and thick spruce swamps, this as invariably frequents the mountain woods. Still their summer food is similar in nature to that of the other, which lives exclusively on the bare plains and low open scrub of the prairie, invariably avoiding the timbered belts so common in those regions. Among other berries and seeds, the Ruffed-grouse feeds largely on those of the small Canadian cistus.*

The plumage of the Ruffed-grouse is exceedingly beautiful. The head, which is a yellowish-red, variegated with dark brown and black, is ornamented with a crest. The lower part of the neck on either side has a dark ruff of long curved feathers, which can be erected at will, but otherwise cover a bare space above the shoulders; the back is a bright brown, finely dotted with white; the tail, which contains eighteen feathers, being of a similar colour, crossed with wavy lines of black, and having a broad band of the same at the end; this band in the 
hen and in young birds is brown. The under parts are yellowish white, marked with dark broken bars. The legs are not feathered so far down as either in the Prairie-hen or in the Canada-grouse. The female does not differ very much from the male; but her ruffs are somewhat smaller and of a browner hue. The general tint, however, of both male and female varies a good deal.

A curious characteristic of this bird is its "drum. ming," a noise well known to backwoodsmen, which is made by the male bird morning and evening from the commencement of the breeding season, i.e., in April. This sound, which is audible at a great distance, few persons would readily believe to proceed from such a source. Wilson informs us that the strokes, which begin slowly and distinctly, are caused by beating the lowered wings on the trunk of some fallen tree; increasing in quickness, they end at last in a continuous rumbling, resembling low distant thunder. During this drumming the ruffs on the shoulders are elevated, the tail is expanded, and the bird wheels and struts about with great pomposity.

These birds make their nest in the month of May, and the female lays about a dozen eggs of a pale yellowish-brown, rather smaller than those of the Prairie-hen. The nest, being artfully concealed among long grass and briars, is seldom discovered. 




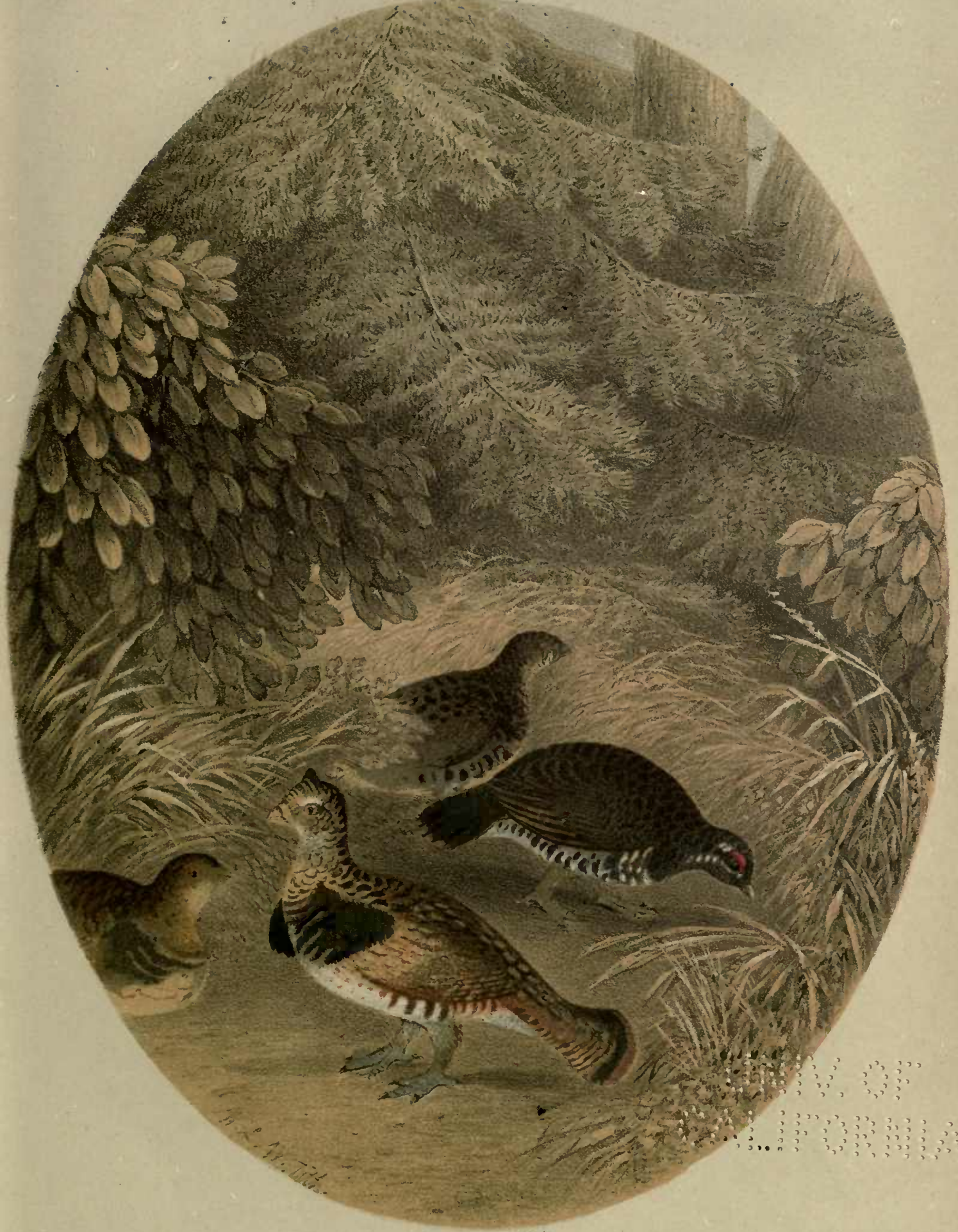



When moving, the Ruffed-grouse jerks its tail after the manner of the water-hen. It is not, as many naturalists affirm, "always found single or in pairs;" for small coveys are much more frequently seen than either, and large ones too are occasionally met with. Though generally difficult to get near, they will sometimes lie pretty close in a thicket, or in high grass, and then rise almost from under the feet with a whirring heavy flutter, very like that of our pheasant; though when under way the flight is swift and steady.

Like the Jungle-fowl of India, which, on the Neilgherries, I have constantly surprised, picking about on the ghauts or mountain passes at dawn of day, the Ruffed-grouse similarly ventures from the woods in search of food, and may be looked for on forest roads in the early morning with more chance of success than in the covert. Open grassy spots are also favourite places of resort; but owing to their wandering propensities, it is impossible to calculate on finding them in the same neighbourhood two days successively.

The season for shooting Ruffed-grouse is from September, to the middle of winter, though after the snow falls there is this objection: that as the birds have then little else to feed on than the "American laurel" or Kalmia, the flesh, if not thereby rendered poisonous-as it probably is, if the bird be left to hang long without 
being drawn-is at all events in inferior condition. This Kalmia is not to be confounded with that already mentioned ( $K$. angustifolia), which is a much smaller plant, and only thrives in low ground. The present one ( $K$. latifolia) is a very ornamental flowering shrub, growing from three to ten feet high on rocky ground and hillsides. Both, however, have the same peculiarity of being innocuous to certain animals and poisonous to others; for instance, as Loudon* states, the latter or broad-leaved shrub, "though poisonous to cattle and sheep is not so to deer;" and it is now shown to be as harmless to this bird as it is the contrary to man.

The Ruffed-grouse is quite common in very many parts of the Lower Province, and in the Ottawa country and Argenteuil district, but does not extend further north than latitude $56^{\circ}$.

This is not by any means an easy bird to kill, and will often fly a long distance after being very hard hit. When wounded, it is exceedingly difficult to find, hiding in holes and hollow tree trunks, in such a manner as to baffle the best retrievers and the patience of the most persevering sportsman. When flushed they seldom fly to any great distance, and invariably settle on the trees instead of again alighting on the ground; generally 
selecting the closest and most thickly covered, so that it is often almost impossible to discover more than half the number of the covey among the sheltering foliage.

The American Colin (Ortyx Virginiana) is one of the prettiest and most interesting little game-birds of Canada. Though called the "quail," and sometimes the "partridge," it is a totally distinct genus from both of them. Larger than the former, it yet bears a general resemblance to it, whilst at the same time it presents some points of similarity to the latter, to which it is in turn much inferior in size. In point of fact it belongs to an intermediate family (Ortygina) peculiar to the Old World, and constituting a sub-family of the Perdicida.

With regard to its usual misnomers, Baird* says, "Where this bird is called quail, the Ruffed-grouse, it will be found, is generally called partridge; and where it is called partridge the larger species is known as the pheasant. In reality, however, no one of these names can be correctly applied to any American species; though to call the Ruffed-grouse a partridge is perhaps a worse misnomer than to apply the same name to the Ortyx."

The latter is characterized by the great comparative depth and thickness of the bill, by very short rounded wings, and proportionally heavy body. The following

* Birds of North America. 
description of the plumage of the Colin is taken from an unusually perfect specimen in my own possession. The upper part of the back is of a reddish colour, changing lower down into a yellowish red, and the under parts are brownish-white, beautifully marked with black curves. The head, which is slightly tufted, is of a reddish brown, with a white streak over the eye, down the neck, and also on the chin, below which is a patch of black spreading over the throat. The sides of the neck are spotted with black and white on a ground of the same colour as the head; the wings and tail are dusky, intermixed with ash-colour and brown. The bill is nearly black, the eye hazel, and the legs a pale bluish grey.

In the female, which is a smaller bird, the chin is the same colour as the rest of the head; this is also destitute of the white markings, and the spots on the neck are yellow and black, in place of white and black, while the breast is nearly white, and the general hue is lighter than that of the male. The colour and markings of the plumage, as is frequently the case with other game-birds, vary considerably in different parts of the countries they frequent.

It is a singular fact that these birds are not found in Lower Canada, though in most parts of the Upper or Western Province they are met with in abun- 
dance, and in autumn evenings may be heard "calling" close to the roadside.

Unlike the quail proper, which is a bird of passage, the Colin is stationary, and perhaps to a greater degree than most non-migratory birds, often evincing extraordinary attachment to particular localities. Though occasionally seen in the woods, I have never myself found them anywhere but in the open country; in the vicinity of broken ground where long grass and twining briars are interwoven; or about the tangled bottoms of snake-fences, and in the neighbourhood of fields of buckwheat or maize, to which they are very partial. In such places I have found them in abundance, and enjoyed the prettiest shooting imaginable. They are often found hiding among the pumpkins, which in the latter fields grow between the rows of corn.

It is in rough neglected places, like the ground first mentioned, that they conceal their most comfortable and ingeniously-made nests, which are covered over with a roof of leaves and fine grass, as a protection against the weather, an entrance being left at the side. They pair in March or April, and during the subsequent period of incubation, which lasts about a month, the male bird sits in the vicinity of the nest, whistling to his mate. Their eggs, which are perfectly white and rather pointed, are often twenty or twenty-four in number. Notwith- 
standing this prolific supply, they have two broods in the year, while the young run about and take care of themselves as soon as they leave the egg-shell, and are able to fly in a fortnight; so that were it not for the great number which are annually drowned in the heavy rains, and either trapped or lost in the severe winters, these birds would no doubt multiply to an extraordinary extent. In 1861 there was a great abundance of them in the western districts of Canada; but last year they were not so plentiful, owing to the above causes operating to reduce their number.

When the snow has excluded them from their usual coverts they may be seen huddled together in a circle on its surface, and remaining in this position during the heavy storms, are often buried in the drifts. In severe weather they appear to have little fear of man, and at all times exhibit a preference for cultivated districts, on account of the supply of grain which they afford; from this cause they have been less disturbed by the advancing tide of emigration than many other birds of more shy disposition.

The call of the cock bird, which during the autumn is loud and frequent, sounds so exactly like the words "Bob White," as to have obtained for it that sobriquet among the Americans.

In Canada the season for shooting the so-called quail 
begins on the 21st of August. When flushed they whirr up suddenly, and will sometimes fly into the trees, but more generally settle on the ground again; notwithstanding their very short flights, they are exceedingly difficult to find, so close do they lie after being thus disturbed.

The flesh, which is white, is very tender and excellent; and this is in every way a bird worthy of the attention of the Acclimatization Society. Pugnacious enough to defend itself anywhere, yet from its size not likely to drive away any other game-bird, it is hardy enough to stand any winter in this country, and appears to thrive, as far as has yet been tried, equally well in the furthest northern as in the most southern parts of England. Yarrel* states that a small number were introduced into this country many years ago, and that specimens have from time to time since that period been killed in Northumberland, Cambridgeshire, Gloucestershire, Surrey, Kent, and Sussex; also that from the discovery of nests and eggs they are known to have bred in Norfolk and Staffordshire.

Though, as above stated, they are very fond of buckwheat and maize, of which they would of course find little with us, they will thrive on any kind of corn, the 
seeds of grasses, and of many of our wild plants, on blackberries, bilberries, cranberries, as well as grubs and insects.

There would be no difficulty in obtaining any number of them, as they are taken alive during the winter in great quantities in the States, by means of traps formed of sticks, with a trigger in the centre, and are to be purchased in many of the markets throughout that season.

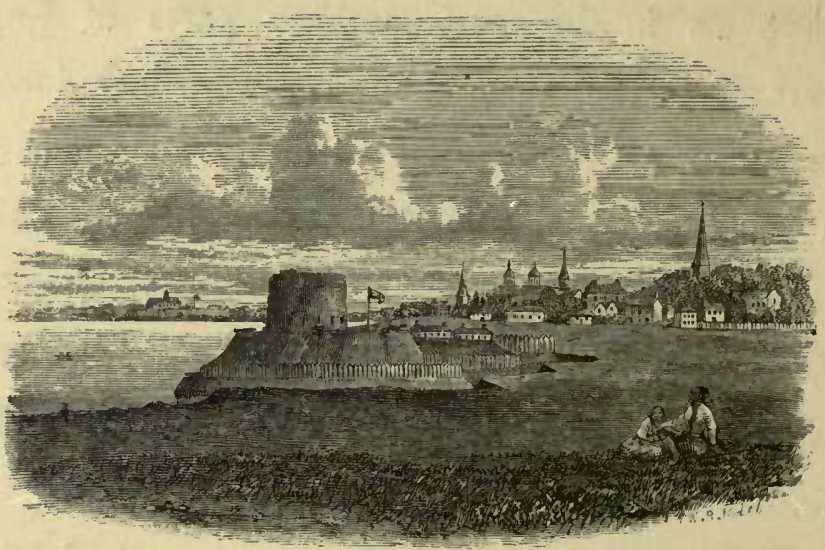

FORT MISSISSISAUGUA. 


\section{CHAPTER VII. \\ Grallatores.}

AMERICAN BITTERN-ITS GENERAL DISTRIBUTION-APPEARANCE-EGGS AND NEST-EXCELLENT FLESH-THE LITTLE BITTERN-GOLDEN PLOVER-DIFFERENT FROM EUROPEAN BIRD-THE RING PLOVERHIGHLY ESTEEMED - THE AMERICAN WOODCOCK - DISTINCT FROM EUROPEAN ONE-DIMENSIONS AND COLOURING-ITS RANGE-LOCALITIES - HABITS - SEASON FOR SHOOTING - COVERTS - DOGS NECESSARY-MIGRATION-THE AMERICAN SNIPE-FOUND IN BUSHY GROUND-COMPARED WITH EUROPEAN SNIPE-NEST AND EGGSMIGRATION TO SOUTH-BIRDS LEFT BEHIND-SHOOTING SEASONDIMINUTION OF SNIPE-RETURN IN SPRING-CURLEW-ESQUIMAUX CURLEW-THE AMERICAN RAIL-ITS EXCELLENCE-PLUMAGE, HABITS, AND FLIGHT. 



\section{CHAPTER VII.}

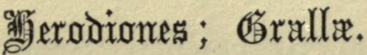

THOUGH the American Bittern (Botaurus lentiginosus) 1 very much resembles the European bird in habit, and makes the same booming noise, it is of a different species. The plumage is a brownish yellow, mottled with two other shades of brown, and the throat is white, while each side of the neck has a broad stripe of black. The feathers on the front of the neck and breast are very long, and hang loosely, the latter, as well as those of the under parts, are of a buff colour. The top of the head, part of the wing, and the tail are a reddish cinnamon colour, the feathers of the latter being very small. The bill is a dull yellow, and the legs are greenish brown. The female is similar in plumage to the male, and the young are a little paler.

It is common to all latitudes of North America and extends through the whole of Canada, being especially abundant in the swampy country through which Baptiste Creek runs. The nest is invariably made in solitary swampy spots, and the eggs, of which the number appears 
very uncertain, are two inches long and one and a half broad, and of an olive colour.

The American Bittern is known in most parts of the country by the name of "Indian Hen," and is not an easy bird to approach. It is generally used by the settlers for making soup; but when in proper condition is considered excellent eating. Specimens of this bird have been shot in Ireland, and Yarrell* mentions several instances of its having been killed in England, and on one occasion in Scotland, near the residence of Sir William Jardine, in Dumfriesshire.

The Little Bittern (Ardetta exilis) is much rarer, and is confined principally to the swamps lying on the southern shore of the St. Lawrence. It is not the same species as the Little Bittern of Southern Europe. In the male the head and upper parts are a glossy dark green; the neck and shoulders purplish chestnut. In the female the head is the same colour as the neck.

That excellent bird, the Golden Plover (Charadius Virginicus), a variety of our species, is found abundantly in different parts of the Lower Province.

Two other well-known plovers are the Semipalmated or King Plover (Egialitis semipalmatus) and the "Killdeer." The former, which is most excellent eating, is

* British Birds. 
also called the Ring Plover, on account of its having a white ring round the neck. The throat and under parts are white, and a black stripe encircles the breast, meeting at the back of the neck below the white ring. The upper parts are ashy brown tinged with olive. There are a few white feathers in the wings, and the bill and legs are yellow. The Killdeer, ${ }^{*}$ familiar in most parts of the country, is so called from its note, but its flesh is not esteemed.

It is a generally received opinion that the Woodcock of North America is identical with ours, and some also believe that it migrates, not regularly, but frequently, from the New World to the Old. The two are, however, quite distinct from one another, and differ considerably in size, plumage, and other points.

The American bird (Philohela minor) is considerably the smaller of the two, seldom exceeding eleven inches in extreme length, while the average measurement of the European one is thirteen and a half; the difference in weight between them being nearly four ounces. In the plumage the most noticeable difference, and one that could hardly fail to be observed even on the most cursory inspection, is that the whole of the under part is of a red hue, growing brighter on the sides and under the 
wings. There are also minor differences, which will be better understood by a description of the general plumage. 'The occiput has three bands of black alternated with three of pale yellowish-red, the upper part of the body being variegated with pale ash or reddish-yellow of different shades, and with lines of black. The throat is ash colour, and a line of very deep brown extends from the eye to the bill, with another of the same colour on the neck. The wings are ashy-brown, and the tail a very dark brown, almost approaching to black; this is tipped with ash colour, darker on the upper surface than on the under, where, in fact, it is often nearly white. The bill is a light brown, and the legs a pale reddish colour.

As to the theory of the transatlantic migration, it is well known that the Woodcock never takes very long flights, which indeed the disproportionately small size of its wings would seem to render laborious, if not altogether impossible, and the only foundation for attributing to it such a feat rests on the fact that a great abundance of Woodcock is found on the west coast of Ireland, where it was not unnaturally supposed birds from America would alight. That they do exist there in larger numbers than in most other parts of the British Isles I can testify from experience, having killed them in extraordinary quantities in several localities when on 
detachment near the mouth of the Shannon; but instead of being the alighting point of the American bird, this coast is in reality the ultima thule of the European one.

The American bird is confined to much warmer latitudes than the other, wintering in the Southern States, and in summer venturing no farther north than the Great Lakes of Canada: climates compared with which an Irish winter would be of a temperature almost fatal to its existence.

It breeds in all parts of Canada from March to May, and sometimes as late as June. The nest is very roughly and clumsily formed, under any prostrate tree or collection of dead branches, and contains four eggs, nearly equal in size to those of the pigeon, and of an olive colour, mottled with pale brown spots. There are generally two broods in the year, the earlier family being watched and taken care of by the male bird during the second incubation of the female, and even until the younger brood is fully grown, or at any rate able to travel, when a brief journey northwards is undertaken by the whole.

In many points, as regards their habits, the American Snipe and Woodcock resemble one another very closely, and are certainly more nearly allied than their congeners of the Old World. The Woodcock, however, moves farther southward than the snipe, and does not appear to 
penetrate nearly so far northward. It may also be added that it remains but a very short period at its northernmost limit; and whilst the snipe passes through Canada to its breeding grounds, the other rests and breeds there, merely visiting a little further north for a few weeks in the early autumn in search of new feeding grounds.

In these migrations they generally make very short nocturnal flights from covert to covert, resting during the day, and feeding at dusk in anticipation of the renewal of - the journey. In the spring their flights are generally longer and more rapid, and at that season they are also observed to travel in pairs; but at all times when on the move they are to be found in almost any swampy ground in the vicinity of covert, in second-growth woods, or in low lying thickets in the neighbourhood of open ground; though never in the forest. Patches of alder, a tree that flourishes in marshy ground, are favourite resorts, and all low rich black soils, which doubtless abound more plentifully in food.

During the heat and glare of the day the birds lie close in the woods and thickets, only venturing forth to feed in the dusk of evening. At this hour they may constantly be seen on the wing in proximity to open swamps or along the margins of rivers; and excepting in bad weather, when their movements are very uncertain, they continue to feed all through the night, only betaking 
themselves at break of day to their shady haunts. These remarks apply of course to the season of non-migration.

As the Woodcock, generally, revisits the place of its birth, those that survive the shooting season will probably return the following year to the coverts in which they have been reared. The season for cock-shooting is nominally from the 1st of August to the 1st of March, but the beginning of November generally sees their departure. It is the practice in the Upper Province to commence on the 15th of July; which is too early, for in some seasons birds are killed not more than threefourths grown, and in late years the old ones may be taken away from half-fledged second broods. Though a fortnight or three weeks makes a difference in this respect it does not in the temperature, and August shooting is anything but easy work in the young woods. Twining stems of the sweet-scented vine cross one's path at every step, while dense briars and rank underwood, meeting the low spreading branches of the black oak and maple, render it as difficult to progress as to raise the gun, or even to get more than a momentary glimpse of the flapping bird, which suddenly rises and as suddenly drops over the bushes out of sight. Add to this the thermometer at $90^{\circ}$, with myriads of musquitoes, and you have a fair idea of summer covert shooting in Canada. In many places I have found these insect torments so 
pertinacious and in such extraordinary numbers, that in spite of a previously well lubricated skin and the aid of tobacco smoke, I have been obliged to carry a green bough in the hand and constantly wave it round the face and neck. However brief a cessation occurred, while firing or loading, the smallest portion of skin exposed was at once seized upon by a hundred thirsty bloodsuckers. I have known even a small rent accidentally made in the clothes to be instantaneously discovered and occupied by as many as could get their heads in.

In the more dense coverts it is seldom possible to get a really fair shot; one fires by instinct, aiming rather at the supposed whereabouts of the bird than at any visible object. If the nature of the ground permits, or the thicket is not too large, it is well to have the guns outside, and let the dogs hunt it alone; but they must be well broken in and accustomed to the work, or they will do more harm than good. For ordinary shooting, nothing is better than a slow old pointer or setter. Under favourable circumstances from eight to ten couple of cock to each gun is considered a fair bag.

At times the birds are so sluggish as hardly to rise, and when flushed at close quarters will only fly very short distances, dropping suddenly with closed wings, and often immediately in front of the dog or gun. This characteristic White has noticed in his "Natural History 
of Selborne" with respect to the woodcock in our own country, and is of opinion that it may always be attributed to the effect of a recent fatiguing journey.

On alighting the Woodcock invariably runs a little distance before squatting, probably with the instinctive idea of baffling discovery, and is always to be found in advance of the spot on which it may have been marked down. When running in this way it carries the tail erect and spread out.

In the beginning of August old and young suddenly disappear, as already described, and only a stray bird is to be found here and there, until about the middle of September, when they return in numbers from their trip up country. At this time they are in first-rate condition, and afford excellent sport till the first sharp frost strips the glowing forest, when they finally depart for their sunny winter-quarters in the far south.

The American Snipe (Gallinago Wilsonii) is, like the preceding, also very generally supposed to be precisely similar to ours, but there are several distinctions of habit and plumage between the two birds.

Though delighting, like its English congener, in swampy grounds, it displays at times a curious predilection for bushy grounds and the outskirts of woods; indeed instances are not wanting of its having been found within the forest itself. It is said also to have 
a peculiar and unsnipe-like habit in the spring of occasionally alighting on rails and branches of trees, to the great wonderment of the sportsman just arrived from the "old country," though I never saw it do so myself.

The plumage is darker than in the European bird, the entire upper parts being of a very deep brown, inclining to black, each feather marked and tipped with light reddish-brown and dirty grey. The neck is a reddish colour, and the under parts are grey barred with very dark brown or black. The wings and tail are also brownish black, and the latter, tipped with a reddish bar, has one or two light coloured feathers on each side.

In point of size also this bird differs from our snipe. While the latter, as most sportsmen are aware, measures thirteen inches in length, the former is only ten and a half inches. These measurements refer to the male only, the female bird of each species being rather larger.

The nest of the American snipe is rude and simple, and is made on the ground without the slightest regard to concealment. It generally contains four pale olive-coloured eggs, rather lengthened in form, and spotted with brown, more thickly so at the obtuse end of the egg. They breed only once in the year, and almost exclusively in the higher latitudes.

The most northern limit of these birds is perhaps 
the Great Bear Lake, and in October they return through Canada (their young broods by that time well grown, and strong enough to accompany them, ) en route southwards to the rice States, where they pass the winter.

I have occasionally seen a stray snipe during the months of December and January in the neighbourhood of St. Catherine's, on the southern shore of Lake Ontario, and in the low grounds west of Chippewa, and have heard of similar exceptional cases in other parts of the country. These detached birds are commonly believed to be permanent inhabitants of the districts in which they are thus met with; but it is much more likely that they have been from some cause or other left behind in the autumn migration, possibly because weak, or hatched very late, and may in that case rejoin the rest in spring on their reappearance in the north. These continually recurring migrations are probably, both with snipe and woodcock, more a matter of necessity than of choice, and may be undertaken either in search of food, owing to the exhaustion of their feeding grounds, or in consequence of the extremes of frost at one season or of drought at another so hardening the mud in which they find their subsistence as to render it impenetrable to their long slender bills. Their frequent halts by the way evidently indicate a desire to travel no further than is requisite, and a succession of 
favourable spots may, by leading them on from one to another, be rather the causes of the migration, than, as is usually supposed, merely halting places for refreshment on a previously projected journey to a distant fixed terminus.

The beginning of August is the legitimate commencement of snipe shooting, and ought to be strictly adhered to, though their destruction in the early spring (that is, before the breeding time, instead of after it) is a practice so general, in the Upper Province at least, and so completely established by custom, that no one appears ever to reflect on the fact that for every couple then killed a whole brood is lost. This practice has contributed in no small degree to their rapid decrease, aided no doubt by a more general drainage and improvement of the land. Many famous snipe grounds in Upper Canada, which I have in former days found literally swarming with birds, are now comparatively deserted, and in order to get good shooting it is necessary to go further afield almost every succeeding year. Of course birds in a state of migration are very uncertain in their haunts, and it may happen that a place which abounds with snipe one season may not afford more than a couple or two the next, and even on consecutive days a similar circumstance may occur; but there is no denying the fact that there is nowhere in Canada at the oresent day anything 
like the quantity of snipe that there used to be a few years ago.

Immediately on the break up of winter they make their reappearance from the south, that is to say, about the end of March or early in April in the Western Province, and about the beginning of May in the Eastern. In many parts of the Niagara district I have at this time seen them so numerous as to rise in a succession of wisps, in the marshes and low-lying grounds, while scattered birds were to be found in every grassy "swale" or hollow of the fields.

Saturated with the rapid melting of several months' accumulated snow, the country literally steams under the increasingly powerful rays of the northward journeying sun, and the ground is so soft and deep that mere walking is of itself severe labour, without the accompanying toil which snipe shooting entails. Sinking ankle deep in the warm mud at each step, and perspiring at every pore, the shooter might fancy himself pursuing his sport in the rice fields of India, were it not for the toil, so distinctively Canadian, which he has to. encounter in clambering over the ever-recurring "snake-fences," eight or ten feet in height: an exercise which for fatigue surpasses anything I have met with in the East.

The Spotted Sandpiper* is common in summer on the

* Tringoides macularius. 
shores of nearly all the lakes, and I have often seen them on the sands in extraordinary abundance. Other species of Sandpiper are also common in Canada.

The Long-billed Curlew (Numenius longirostris) is also very abundant, but it varies so greatly in size, colour, and length of bill, that different specimens have often been mistaken for different species or varieties.

The Esquimaux Curlew ( $N$. borealis of Latham, not of Wilson) is smaller and has a shorter bill than the above, nor is it so common. The upper parts are brownish black, marked with dull yellow; the under parts grey, with a reddish tinge; the neck, breast, and sides are barred with dark brown. The tail is brown, with black bands, and the bill dark and rather yellow at the base; the legs dirty green.

The American Rail (Rallus Virginianus) is an excellent little bird, its flesh much resembling that of the woodcock, and deservedly ranks among the game of the country. In size it is somewhat smaller than our Rail, and its plumage is also rather different. The top of the head is black, and the cheeks ash-coloured, with two white marks on them; the chin is also white. The upper parts of the body are streaked with black and brown, the throat and breast are bright brown, and there are a few white feathers on the sides and wings. The bill is red and the legs dark coloured. 
In running the Rail flits up its tail like the water-hen, and on the slightest alarm hides among the long grass or reeds, away from which it seldom strays very far. When forced to rise, it flies only short distances and very awkwardly and with apparent difficulty, keeping near the ground, with its legs hanging. Like most of its order it feeds chiefly on worms, grubs, and insects. The eggs of this Rail are very beautiful, from eight to ten in number, and of a cream colour, spotted with purple and red. It migrates southwards in winter, and, I believe, breeds in the salt swamps of the States.

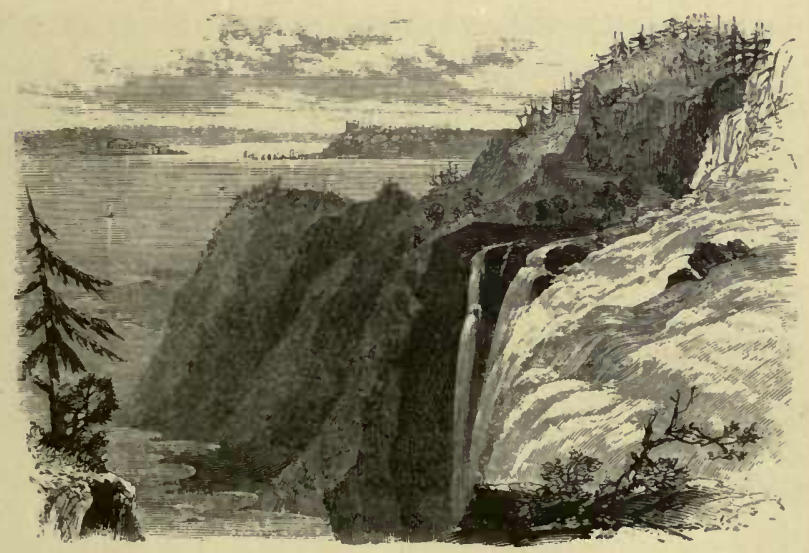

FALLS OF MONTACOREXCT. 



\section{CHAPTER VIII.}

\section{Adatatores.}

QUANTITY OF WILD-FOWL ANNUALLY PASSING OVER CANADA-BREEDING GROUNDS IN THE NORTH-BRITISH AND AMERICAN GENERA, SPECIES, AND VARIETIES-THE TRUMPETER SWAN-THE AMERICAN SWANTHE WHITE-FRONTED GOOSE-DARK-FRONTED GOOSE - THE SNOW GOOSE-THE CANADA GOOSE-THE BRENT GOOSE-THE WILD DUCK OR MALLARD-THE DUSKY DUCK-THE SHOVELLER - THE GADWALLTHE AMERICAN PINTAIL-THE AMERICAN TEAL-THE BLUE-WINGED TEAL-THE AMERICAN WIDGEON-THE WOOD DUCK-OCEANIC DUCKS - THE SCAUP - ORIGIN OF NAME - THE' AMERICAN SCAUP - NOT MENTIONED BY NATURALISTS-THE RING-NECKED DUCK-CANVASBACK DUCK-RED-HEADED DUCK-THE BUFFLE-HEADED DUCK-THE GOLDEN EYE-THE HÁRLEQUIN DUCK-THE LONG-TAILED DUCKSURF SCOTER-HURON SCOTER-VELVET DUCK-EIDER DUCK-RUDDY DUCK-THE LABRADOR DUCK-THE SMEW-HOODED MERGANSERRED-BREASTED MERGANSER-GOOSANDER. 



\section{CHAPTER VIII.}

\section{dinseres.}

COUNTRY like Canada, boasting a far larger extent
of lake and river than any other under the sun, will be readily supposed to be inferior to none in the abundance and variety of its waterfowl; and there are, I believe, not less than thirty-three different species of swans, geese, and ducks (exclusive of "divers"); while of many of these genera and species the individual numbers are almost beyond belief in the districts where they breed, and whence they are annually dispersed throughout the country.

Mr. Barnston, of the Hudson's Bay Company's Service, ${ }^{*}$ says, "It is very difficult to make any just calculation of the number of geese in the northern breeding grounds; but it is known that the number killed on the coast by the Indians and others as food, amounts to about 74,000 annually; allowing for wounded birds dying or being killed by wild animals, would make this

* Can. Nat. Geo. Montreaī, Oct., 1861. 
80,000 . Calculating that for every bird killed, twenty escaped untouched, and that large flocks remain entirely undisturbed in remote districts, it would follow that the number of geese leaving their breeding grounds by the Hudson's Bay route for the south, must be about 1,200,000." Of the numbers that take their flight straight across the country it is difficult to form more than a very vague idea, but the writer in question, computing it at probably two-thirds or more of the former quantity, estimates the flocks that annually pass over the continent at not less than 2,000,000, without including the Brent geese, which are neglected by the Indian tribes generally.

Besides this enormous number of geese, the Swans and the majority of the two great divisions of True and Oceanic Ducks, also breed either in the extreme north of Canada, and the Hudson's Bay territories, or just within the arctic circle; and also migrate with their grown-up families in the autumn to the Southern States and the Atlantic coast, returning northward again in the spring; thus traversing the whole of Canada twice annually. - Hence it is that Canadian wildfowl shooting is perhaps the best in the world, and in the former of these two - seasons especially, no sport could be more delightful. The autumn forest literally glows with the brightest crimson, purple, scarlet, and yellow, intermingled with the dark pine; the atmosphere is warm, yet bracing, 
and when the blue haze of the "Indian summer" spreads through and over the mellow landscape, the stillness is such that the boatman's voice a mile out on the calm lake, each blow of the distant woodsman's axe, or the cry of far-off waterfowl echo through the air with a distinctness which is perfectly marvellous.

Many localities are noted year after year as being especially resorted to during these migrations : a circumstance which may be accounted for as well by the nature and abundance of the food and shelter they afford, as by the fact that the Anatidæ generally, unless systematically disturbed, will annually seek food and rest at the same halting-places along their route.

As instances, Green Island, Cacouna, and other places in the Lower Province; Long Point Island on Lake Erie; Turkey Point, nine or ten miles from it; Burlington Bay, on Lake Ontario; Baptiste Creek, and last, though not least, the St. Clair River, have long enjoyed their present a fame. At the latter, Captain Strachan of Toronto, a wellknown sportsman, with only one other gun, lately killed no less than four wild swans, ten wild geese, and 685 ducks of different kinds in sixteen days. The variety, too, of the wildfowl in these and a hundred other places is most remarkable, and whether with the naturalist or mere sportsman adds immensely to the pleasure of the day's shooting. 
Though the quantity of birds is so immense that no amount of fair shooting will ever seriously affect it, yet the systematic destruction and removal of the eggs which the last Report of the "Montreal Game Protection Club" states has been carried on annually in the spring in a wholesale way, especially about lakes St. Francis and St. Peter, and the marshes adjacent, must in time do incalculable injury. The public protests of this body and of the Natural History Society will probably put a stop to the continuance of these practices, as well as to shooting in the spring months, so that the wildfowl of Canada may be for many years to come preserved from the general destruction which otherwise threatens them.

Several of the genera and species here enumerated will be recognised as being also either permanent inhabitants of, or winter visitors to Great Britain; and others as being common to different parts of Europe; but many of the most beautiful and highly esteemed are peculiar to North America.

The first among the numerous host, from its size, importance and great beauty, is the Trumpeter Swan (Cygnus buccinator), known also as the "Hunter's Swan," which is peculiar to North America, and is a magnificent bird, in size exceeding the European Hooper. Wilson says it breeds as far south as latitude $61^{\circ}$, but prin- 
cipally within the arctic circle, and in its migrations generally precedes the geese a few days.

It is, with the exception of the eagles, the earliest of all the migratory birds in spring. It arrives in the fur countries earlier than the Canada goose, and frequents the eddies under waterfalls, and other spots of open water until the frozen rivers and lakes break up. They are met with both in the interior and on the sea-coast, sometimes in small flocks, but more frequently in pairs. The skins are an important article of commerce in the Hudson's Bay territory.

The American Swan (Cygnus Americanus) is also quite distinct from any of the swans of Europe. It is less common than the above, and somewhat smaller, but still of splendid proportions, its length being about four feet six inches, and its average weight twenty-one ppounds. The bill and fore part of the head are black, with a space of orange at the base of the former. The head is tinged with yellowish red, but the rest of the plumage is perfectly white. The female is of similar plumage, though smaller in size. The legs and feet are black in both. The young birds are of a bluish tint, with the bill and feet light coloured.

The food of the swan is entirely vegetable, consisting principally of the roots and stems of water-plants; and the St. Clair Marshes may be named as one of its favourite haunts within Canadian territory. 
The White-fronted Goose (Anser albifrons) of Canada, is the same bird as that so well known as a winter visitor to Great Britain, and in both countries goes also by the name of the "Laughing Goose." The latter name it owes to the peculiarity of its note or call, which somewhat resembles the sound of laughter. The former of the appellations refers to the distinguishing band and frontlet of white feathers at the base of the bill and on the forehead. On this account (though generally adopting Baird's nomenclature) I have rejected his name of Gambelii, as the unde derivatur appears less appropriate than that of Albifrons, by which too it is more generally known.

It appears to be very widely distributed, being equally well known in Lapland, Sweden, Norway, Russia, Germany, Italy, China and Japan. In North America it migrates a few days later than the Canada goose, and breeds much further to the north. The eggs are a dull blotchy green.

The prevailing colour of the plumage is a brownish ash; and the lower parts are barred and patched with black, merging into white nearer the vent. The legs and feet are orange, and the bill a flesh colour. The plumage of the female is similar to that of the malewhich is a characteristic of the genus Anser; but she is of smaller size. The flesh is excellent.

The Dark-fronted Goose (Anser frontalis) differs 
from the above in having a very dark mark round the base of the bill in place of a white one. It is found mostly in the interior of the country, and is believed by Baird to be a new and undescribed species, not being mentioned by any other writer.

The Snow Goose (Anser hyperboreus) is a much smaller bird. than the Canada goose, migrates later in the season, and is to be seen both inland and on the coast. It has a high shrill note, entirely different from either the Canada or the white-fronted goose.

The plumage is perfectly white, with the exception of the forehead, which is of a reddish brown; the wings are marked with black and ash colour. The legs, feet, and bill are of a purple pink, the mandibles of the latter being serrated both above and below. The food consists principally of the roots of reeds and other aquatic plants, and the flesh is extremely delicate.

The Canada Goose (Bernicla Canadensis), which is the common wild goose of the country, in reality neither breeds nor resides in it, but passes the summer and autumn in the Hudson's Bay country, or even in still higher latitudes, and winters among the inlets and river mouths lying along the Atlantic coast, as far south as the Carolinas.

It is during its migration to and from these opposite points, namely, in September and October when moving 
southward, and in April and May on returning to its northern home, that it makes its appearance in Canada, halting on the way for rest and food, sometimes for several days together.

Observing fixed routes, it has been found that unless prevented by fogs, storms, or the presence of man, these birds also select the same spots year after year as resting places, attractive as possessing the important desiderata of sufficiency of food, solitude, and openness of situation. They invariably avoid any approach to cover likely to conceal an enemy, and seldom alight where there is not a clear space all round, at all times maintaining so vigilant a look-out that it is exceedingly difficult to get within range. Among other favourite halting places may be mentioned Green Island, and Cacouna, in the Eastern Province, where at these periods they are always to be found in great abundance. On the wing it is impossible to reach them except with the rifle: a shot hardly worth the experiment; for owing to their mode of flight, which, according to the number of the flock, is either in Indian file or in two lines converging to a point, it is impossible to hit more than a single bird, while the speed at which they fly and the great altitude invariably maintained would render this a great chance.

In the thick fogs which so often prevail at the commencement of winter they frequently alight, unable to 
distinguish their landmarks and uncertain what direction to pursue. When this happens they sometimes fall an easy prey to the gun. I myself on one occasion came suddenly close upon half-a-dozen of them in a field by the wayside.

The Crees and other northern tribes, concealed by temporary coverings of boughs, erected at short intervals in a straight line across country, attract them by setting up as decoys on the wide marshes in their course several of those previously shot, and then imitating the bird's clarionet-like call. This they do so correctly as seldom to fail in bringing the passing flock within range of their fowling-pieces.

To such an extent are the different methods of destruction carried on throughout their perilous route, that though at its commencement the flocks are large and numerous, they soon become so broken up that further south their passage ceases to be watched for.

The return of the survivors northward, sooner or later, at the commencement of the following year, is always regarded as a sign of a late or early spring. Though on leaving winter-quarters they are in very poor condition, the change to inland diet appears to fatten them so rapidly that by the time they reach the northern regions, where they constitute an important item of food, and are anxiously watched for, they are in first-rate 
order. When resting for the night, these birds, notwithstanding their excessive caution, do not, like other wary waterfowl, resort to the open waters of the lakes, but roost in the middle of the swamps and marshes in which they have fed during the day.

In form and appearance the Canada goose is widely different from that universally distributed domestic bird, the ungainly figure and attitudes of which are so apt to suggest themselves to the mind as types of the genus. There is a great difference among them in colour and size, but the Canada goose is always a larger and heavier bird than the other; its neck is much more slender, the form altogether is more symmetrical, and the harmony of colour more pleasing to the eye than that of any other of its kind.

The head and neck, as well as the bill, are black, with a remarkable white patch on each cheek, meeting under the chin. The back and wing-coverts are brown, margined with white; the wings and tail black; the lower part of the neck white; and the breast and belly light brown. The rest of the under parts are of a greyish white, the legs and feet being nearly black.

The female, which is of precisely similar plumage, generally makes her nest on the ground, and lays from six to eight eggs, of a pale green. Though the male bird does not assist in the task of incubation, he care- 
fully guards his mate during that period, and is always to be seen on sentry in her immediate neighbourhood. After it is over the old birds moult, and immense numbers are chased with dogs and canoes, and killed by the Indians and others, when unable from this cause to take wing, and many of their young share the same fate; so that their whole existence is a scene of danger and alarm froin its earliest noments.

The flesh of the Canada goose is extremely nutritious and well flavoured, owing doubtless in some measure to the nature of its food. In the winter months, when on the coast, this consists chiefly, according to Wilson, of the broad tender leaves of a marine plant which grows on stones and shells, and is usually called "sea cabbage;" as also the roots of the sedge, which they are frequently observed in the act of tearing up. During their inland journeys and at other times they live on grass, various kinds of leaves, and seeds, with maize and corn when they are to be obtained.

The Canada goose is often to be seen in a domestic state among the settlers, and has for many years been recognised as a valuable addition to our own farmyards, being found to breed freely with other kinds, but its superior size and flavour render it well worthy of far more extensive and special propagation.

Many instances are mentioned in which this bird has 
been met with in a wild state in parts of England-a fact one can only account for on the supposition either of its having crossed the Atlantic, or escaped from owners in this country. I have myself known an instance in which half-a-dozen, led away by the passing overhead of a flock of common Brent geese, deserted a farm where they had been long domesticated.

The Brent (Bernicla brenta), although common round Hudson's Bay, and migrating annually, like its congeners, to the Southern States, performs the whole journey far out seaward, and is seldom seen in Canada.

The common Wild-duck, or Mallard (Anas boschus), is found during the summer and autumn in nearly every district of Canada, and being precisely similar to that of Europe, is of course too familiar to need description.

Though with us most abundant in winter, flocking in from colder and more northern regions, in Canada they are similarly compelled by the intense cold and the impossibility of obtaining food to migrate further south, and wend their way, on the first sign of coming snow, to the Southern States, where they remain throughout the winter, the majority resorting to the submerged rice fields, in which they are said to. find abundant food. The vast numbers thus on the move in all quarters of the country afford excellent sport in the months of October and November. 
It is not uncommon in some parts to meet with stray birds in early spring; but whether these have passed the winter in the neighbourhood where they are found, or have simply returned from their winter migration earlier than usual, I am not able to say.

Unlike the tame duck, which is polygamous, the wild one invariably pairs. They breed extensively in the wilds of northern Canada, and on some of the smaller and less known lakes and solitary streams are met with in almost countless numbers, associating there, as elsewhere, with pintail, blue-winged teal, and other members of the family. They are also known to breed in less remote parts of the country, though not to any extent.

The nest, although generally placed on the ground, is not invariably so, neither is it always in the vicinity of water; and the eggs, which are pale greenish, vary in number from half-a-dozen to a dozen. During the period of incubation the male assumes the plumage of the female.

The food of the wild duck is of various kinds: grass, seeds, corn, small shell-fish, worms, young fry, slugs, and insects all appear equally welcome.

Duck shooting is much the same sport all the world over, though there are some plans in Canada which would not so well repay the trouble in this country, where ducks are not to be seen in such immense flocks. 
Sometimes the shooter, lying at his length in a small canoe, is carefully covered over and concealed by sapins, or green branches. Having his loaded guns ready pointed over the bows, he either gently paddles himself, or is borne along the stream, unheeded or unobserved, to within the closest requisite range of his unsuspecting victims. In early winter the stratagem is occasionally varied by the substitution of a white-painted scow-which is a flatbottomed boat, square at both ends-the shooter therein being either covered over with a sheet or dressed in flannel. This plan, when the water is studded with floating masses of ice, answers most admirably.

A good shot may often be got at birds circling overhead, as they generally do, after the report of a gun, if ignorant of the point whence the alarm proceeds. On many open waters wild-fowl may be got at under cover of the tall grass or reeds growing on the edge, but in places where this is not practicable and they are equally unapproachable in other ways, it is a good plan to send a person round in an opposite direction to drive them towards the shooter, who carefully conceals himself beforehand.

I remember on one occasion stalking a pond which every evening in autumn was known to be covered with ducks, but lay too low to reconnoitre with the glass, and in the centre of a bare open plain, with no cover but 
a few rushes and tufts of long grass close to the water's edge. Approaching in a stooping position from the leeward, a point gained by a considerable circuit, it soon became necessary to go on hands and feet, then to worm our weary way, ventre à terre, gazing wistfully in our short intervals of rest, towards the friendly rushes. Pushing our guns before us at each length gained, and plastering ourselves with mud, the pond was at length gained without our having alarmed a single bird. With fingers on the trigger, we ventured to lift our heads inch by inch over the coarse grass till the water under our very noses was scanned, but not a sign of life stirred the face of the placid pool.

In some parts of the Lower Province decoy ducks are used, though chiefly by those who make a trade of duck shooting. A more legitimate practice, common among sportsmen, is that of building screens of boughs at spots frequented by the birds for the purpose of feeding.

At a lagoon or stagnant pool on the southern Canadian shore of Lake Ontario, overgrown with aquatic plants, a good many ducks and teal were sometimes to be found during the season, and by constructing these caches at different points of the wood which encircled the banks, we were enabled to rake and enfilade the pool in every direction. Early in the afternoon 
pintail, teal, and mallard came across from the lake, on the open waters of which they appeared to pass the greater part of the day, and circling warily round and round alighted in successive flocks, apparently finding abundance of food in the stagnant weed-grown water.

While lying in wait $I$ have sometimes become so absorbed in contemplation of the animal life around, as to have forgotten what had brought me there. A frequent fellow-watcher at our lagoon was a large osprey, which perched motionless on the bare worn bough of an overhanging tree, sat for hours peering keenly into the pool below. On a sudden he would dart with lightning velocity on his finny prize, and bearing it aloft sail majestically away to his solitary haunts in the neighbouring forest. Hundreds of tortoises, called "terrapines,"* covered the decaying trunks of the floating trees, sunning themselves in long rows with outstretched necks, ready at the slightest alarm or movement to disappear instantaneously under the sheltering duck-weed;

* Terrapene clausa. These small tortoises are of uniform dark colour, and lay their eggs in May and June in the hollow banks of stagnant waters; the very young ones are seldom seen. There is a larger species found in the lakes (Gymnopus spiniferus), which may be caught with a hook baited with a bit of fish; their flesh is very delicate. The eggs of this species, fifty or sixty in number, are found in nooks of rocks and in dead trees. It is not nearly so common as the Terrapine, which may be scen almost anywhere. Terrapine soup is much esteemed in the States, though it resembles anything rather than turtle. 
enormous bull-frogs* crawled and hopped in the shallows, and musk-ratsi swam from bank to bank.

None but those who have thus idled away the hours of a glorious autumn day can form an adequate idea of the charm and interest attaching to such studies of animal life.

Stalking ducks, however, affords by far the best sport, requiring as it often does very great skill, especially when it is necessary to approach a flock some distance out on the open water. The landmarks and bearings being carefully noted, the shooter, after making a sufficient détour, on arriving at the point of advance, commences, according to the nature of the intervening ground, to glide stealthily forward, dodging behind every tree and bush; sometimes bent nearly double, or in default of cover crawling on hands and knees through the grass. If the birds are diving or feeding, the moment must be watched when two or three are under water together, or have their tails simultaneously upturned; then dashing rapidly forward he should frighten away the rest, to prevent their giving alarm, and gain the nearest cover before the divers reappear. If this manœuvre be successfully accomplished, he may pause a moment to recover his steadiness of hand, for the absence of the other 
dueks will not be regarded, even if noticed. If, therefore, he finds himself still too far from his objects, he may wait patiently for the moment when they again dive, which they will very soon do, and then gaining the water's edge he will get a splendid right and left, as they return to the surface and when they rise on the wing; which be it remembered, all wildfowl do with their heads to the wind.

The Dusky-duck ( $A$. obscura) is purely North American, and does not appear to be of migratory habit, having been found to breed in nearly all latitudes of that continent, in the marshes of the interior as well as among the rocks of the coast. Their eggs are twelve in number, and white.

The whole plumage is of a dusky brown, the head and a portion of neck being marked with a ferw streaks of buff, and the wings relieved by an iridescent speculum surrounded by deep black as in the mallard. The inner or under sides of the wings are pure white, conspicuous only when in the air. The bill is a greenish yellow, and the legs dusky orange.

The female is smaller and rather browner in colour; but she has the speculum as well as the male.

They do not appear to be particular as to the nature of their food, and take anything that comes in the way, notwithstanding which their flesh is considered very good. 
They are a wild and easily alarmed bird, and are not to be approached without the greatest caution, and under the most favourable circumstances.

The Shoveller (Spatula clypeata) which is called also the Shovel-bill, the Blue-winged Shoveller, and the Broad-bill, is abundant in some parts of North America, and its flesh is deservedly very highly estecmed, though its food is by no means entirely of that vegetable nature which is supposed to be so conducive to excellence, consisting, we are told, in a great measure of worms, leeches, fish, and snails! Audubon says, " no sportsman who is a judge will ever go by a Shoveller to shoot a canvas-back." But without going so far as this, there is no question as to the exceedingly delicate and tender nature of its flesh.

The Shoveller is called so from the form of its bill, which is broad and flattened at the end, and if not very like a shovel in appearance, answers much the same purpose in the shallow waters where the bird principally finds its food. In addition to its properties as a spade it possesses also those of a sieve, the edges of both upper and lower mandibles being curiously furnished with a comb-like fringe, adapted to and corresponding with each other in such a manner as to allow the escape of water, while retaining the most minute worms, leeches, or aquatic insects. 
This admirable formation is not found to exist in newly-hatched young, or even in those some weeks old, but is gradually developed with their growth.* In plumage, the Shoveller is remarkably handsome; the head is a fine iridescent green and purple, extending about halfway down the neck, the lower parts of which and the breast are white. The belly is chestnut; the back dark brown; the smaller wing-coverts, points of the wings, and tertials, are sky-blue; the speculum is bright green margined with white, and the tail is short and dark. The bill which is so marked a feature, is nearly black and about three inches long; the broad end being an inch and a quarter across. In the female, the under mandible is a reddish hue, the head is a spotted brown, and the plumage differs in one or two other minor points. The young of both sexes are similar to one another in plumage for some time after they are able to run about, and the distinguishing plumage of the male is developed very gradually. This circumstance, common also to other birds, is naturally accounted for by White, $\uparrow$ who says, "no doubt the reason why the sex of birds in their first

* Wilson, Amer. Orn., says, "The young are at first very shapeless and ugly, for the bill is then as broad as the body, and seems too great a weight for the little bird to carry." He however writes this only on hearsay, while the contrary fact is vouched for by Yarrell on his own personal knowledge. 
plumage is so difficult to be distinguished is, because they are not to pair and discharge their parental functions till the ensuing spring. As colours seem to be the chief external sexual distinction in many birds, these colours do not take place till sexual attachments begin to obtain; and the case is the same in quadrupeds, among whom, in their younger days, the sexes differ but little; but as they advance to maturity, horns, and shaggy manes, and brawny necks, \&c., strongly discriminate the male from the female. We may instance still further in our own species, where a beard and stronger features are usually characteristic of the male sex: but this diversity does not take place in earlier life; for a beautiful youth shall be so like a beautiful girl that the difference shall not be discernible."

The periodical assumption by the male bird, of female plumage after maturity, is not so rationally to be accounted for; the drake of this species, as with the mallard, pintail, and other ducks, assuming, at certain seasons, at least to a great extent, the markings and general hue of the opposite sex. In summer it entirely loses the green of the head and neck, and in several other respects adopts the garb of its mate.

The Shoveller's nest is never far from the water's edge, though always placed above the chance of inundation. It contains twelve or fourteen pale opaque green eggs. 
This is the same bird as the European Shoveller, which is a frequent winter visitor to the eastern coast of England, though unknown in Scotland.

The Gadwall (Chaulelasmus streperus) is a shy and cunning bird, ever on the watch against surprise, diving at the slightest appearance of danger, and secreting itself so effectually in grass, reeds, or other convenient cover, as generally to elude the strictest search. Even when forced to take wing it is not an easy bird to kill, its flight being remarkably swift and strong. These two facts, taken in connection with the excellence of its flesh, render it an important and coveted addition to the game-bag.

Its food is chiefly vegetable, though it appears to find abundance of other matter in the reedy ponds, where it may be seen feeding during the day, as well as at the more usual duck hours of evening and early morning.

Its note is harsh and loud, whence its specific name; the ordinary one of Gadwall, we are told by Yarrell, signifying Grey duck, though how or why is not clear.

The Gadwall is well known in many parts of Europe, and is an occasional winter visitor in England, though by no means common, and McGillivray says it has not hitherto occurred in Scotland. In North America it breeds in the Hudson's Bay country, and migrates like the rest of its kind to the Southern States in winter.

The female lays six or eight eggs of a clear grey 
shaded with green; the nest being composed of dry grass and lined with down from her own breast.

The head, and upper part of the neck are a speckled brown, the lower part and breast darker, thickly marked with semicircles of light grey. The back and sides are grey, covered with undulating lines; the smaller wingcoverts are chestnut, and the speculum black and white; tail-coverts greenish black, and tail grey. The bill is dusky and the legs and feet orange. In the female the colours are darker, and the brown more predominant.

The American Pintail (Dafila acuta) is remarkable for its flavour and excellence, being even superior in these respects to the much-esteemed Pintail which in winter visits our own coasts and inland waters, though in most other points the two appear to be very similar.

The American Pintail is a handsomely-shaped duck, of a medium size, weighing about two pounds; the body is much elongated, and the neck unusually tapering. The head is brown; the back of the neck, which is nearly black, being tinged with purple. The back is pencilled over with wavy black lines; the front of the neck, the breast, and belly are white, and the wings brown, with a green spot or speculum. The tail is long and pointed, and is remarkable for two projecting black feathers, whence the origin of the bird's name; the rest are greyish brown. The bill is slate colour, and the legs and feet dusky. 
In the female the centre tail feathers are shorter, and the outer ones darker, than in the male. The neck, breast, and belly are pale brown, speckled with a darker shade; the purple tinge on the back of the neck is wanting, and the upper surface of the body is dark brown, marked with black and lighter brown.

The Pintail Duck exhibits more remarkably than any other the singular transformation of plumage already noticed in the shoveller and mallard, and common to others, of this family, the male during a part of the summer exactly resembling the female. Yarrell's* minute description of the change will better explain it. He says, "This alteration commences in July, partly effected by some new feathers, and partly by a change in the colour of many of the old ones. At first one or more brown spots appear in the white surface on front of the neck; these spots increase in number rapidly, till the whole head, neck, breast, and under surface have become brown; the scapulars, wing-coverts, and tertials undergo by degrees the same change from grey to brown. I have seen a single white spot remaining on the breast as late as the 4th of August, but generally by that time the males can only be distinguished from females of the same species by their larger size, and their belly 
remaining of a pale blue colour. In the female the bill is always of a dark brown.

"At the autumn moult the males again assume with their new feathers the colours peculiar to their sex; but the assumption is gradual. White spots first appear among the brown feathers on the front of the neck; by the end of the second week in October the front of the neck and breast is mottled with brown and white, and at the end of the third week in October a few brown spots only remain on the white."

The Pintail, besides the usual productions of muddy swamps and pond life, feeds largely in autumn on the mast of the beech, in search of which it is often discovered wandering about under the trees at a considerable distance from any water. Pintail are at times abun. dant on and around the lakes, feeding in all the pools and marshes in their vicinity, but are excessively cautious, sleeping far out on the open waters by night; very generally also they rest there during great part of the day.

I have seen numbers of them late in the month of October on Lake Ontario, sometimes in noisy chattering groups, though more often being lazily rocked to sleep on the gently heaving surface of the deep blue waters. Although apparently always dozing, they evidently keep one eye open; for however many ducks 
of other kinds may be around, the Pintail is always the first to give the alarm. They are generally at a sufficient distance to be out of range from shore, and it is useless to attempt to get a shot at them by approaching in a boat. The only plan, therefore, is to lie in wait, secreted near the swamp or low ground which they are noticed to frequent, and to which, late in the afternoon, they are sure to flock for the purpose of feeding.

As this ambush should be continued so long as there is any chance of fresh flocks arriving, that is, till after dusk, it is necessary to mark carefully the spots where the dead birds fall, in order that they may be afterwards recovered by the retriever, which, till then, of course should not be permitted to leave the cache, or place of concealment, on any account.

The Pintail breeds in the solitary tracts far north, visiting Canada in the Fall, en route to Mexico. Its nest is formed amongst thick rushes, and the eggs are eight or nine in number, and of a greenish blue, and not "dull chocolate colour," as certain writers have affirmed.

The immature birds are often mistaken for those of some other species, as they are without the long tail feathers, and their plumage displays the characteristics of both male and female equally.

Wilson, after a careful examination and comparison of the American Teal (Nettion Carolinensis) with that of 
Europe, says that both are undoubtedly of one and the same species, and that there is no more difference between them in size, colour, or markings than such as commonly occurs among individuals of any other tribe. Yarrell,* on the contrary, in his account of the European Teal, says that it is quite distinct from that of North America.

When such two high authorities differ so widely in opinion, it is unnecessary here to do more than simply describe the plumage and habits of the one found in Canada, which generally goes by the name of the "Greenwinged Teal," and is as prettily marked and as excellent a bird as the much esteemed teal of our own country.

In the male the head is a beautiful chestnut, with a broad patch of green running backwards from the eye, bordered above and below by a line of buff. The sides and back are closely marked with fine wavy black lines. The primaries and wing-coverts are brownish ash-colour, and the speculum light green, with a narrow border of cream colour above and below, and one of black at either side. The breast is beautifully marked with black spots on a pale purplish ground, the under parts are white and the tail brown. The bill is black, and legs and feet flesh coloured.

* British Birds, iii. 285. 
In the female the head is simply white, spotted with black: the back is a striped brown, and the breast a speckled brown. The males frequently assume this plumage.

The green-winged Teal breeds in the northern regions of Canada, but chiefly in that great nursery of ducklings, the Hudson's Bay country, and frequents all the feeding grounds southward throughout both Provinces during the autumn. They go south in October, and further so than most other species. The nest, which is secreted among the long reeds growing at the water's edge, and is not to be found without wading, is very large in proportion to the size of the bird, being composed of an immense quantity of dead grass, rushes, and leaves, and lined with feathers. The eggs vary from eight to twelve in number, and are white, spotted with brown.

Though these Teal are frequently seen in company with other ducks of various kinds on the water, yet when flying they keep exclusively together, and generally in small parties, darting through the air also with great rapidity.

Their food is almost entirely vegetable, and in search of it they frequent swampy river mouths, shallows, and lagoons, the wild rice growing in these localities being a great attraction to them, as it is to most other ducks.

The Blue.winged Teal (Querquedula discors), which, 
if I am not mistaken, is exclusively North American, is widely distributed through Canada, breeding also in many parts of it, the rude and simple nest being often found among the grassy tufts of rough sedgy swamps and by the rush-grown margins of quiet inlets. It contains half-a-dozen or more eggs of a dirty white, spotted with brown.

Its food is chiefly vegetable, and in excellence of flesh this duck is only equalled by the Canvas-back, to which, indeed, some even think it superior. It appears to be always in first-rate condition, though it is a very small duck, weighing not more than twelve or thirteen ounces.

The Blue-winged Teal is extremely susceptible of cold, and on the first appearance of autumnal frost betakes itself to the Southern States and Mexico, where it passes the winter in a climate more congenial to its frame.

The general plumage is dark, the head and neck being varied with green and purple reflections, and the breast and back beautifully marked with buff, while the belly is a light brown. The smaller wing-coverts are of a bright sky-blue, from which it obtains its name; the tail is a rich brown, and rather long. The bill is lead colour, but the legs and feet are a dull yellow.

In the female there is not much difference of plumage beyond the absence of the purple and green on the head and neck. 
In the months of April and May the Blue-wing teal reappear from their southern sojourn, and are again dispersed over the country. Their flight, like that of many other of their kind, is very rapid; but they have a habit peculiar to themselves of alighting with great abruptness, dropping through the air like a stone over the spot on which they intend to rest. Their favourite resorts are sheltered mud banks, where, after feeding, they sit preening their feathers and enjoying the warmth of the early summer sun. At such times it is not diff. cult to get within shot; indeed they are habitually less wary and cautious than any of their kind.

The American Widgeon (Mareca Americana) differs from that of Europe in several respects, the most important being in the formation and smaller size of the trachea. The external differences are also sufficiently marked, for it is a larger bird, and its neck and cheeks, in lieu of chestnut, as in the latter, are yellowish white, speckled with black; the top of the head is cream colour and on either side green. The bill is longer, more slender, and of darker colour than that of the European bird. They migrate to the Middle and Southern States in small flocks in October, but return generally in pairs at the break-up of winter to the Hudson's Bay districts, where they breed. They are not so common as many of the above kinds. 
The Widgeon feeds entirely by day, and though found during their inland life to subsist on worms and insects of different kinds, their food while on the coast is principally the valisneria, for the purpose of obtaining which, Wilson tells us, they frequent the company of the Canvas-back duck, and being themselves less able to dive for the much-prized root, live by plundering the iatter the instant they reappear on the surface of the water with the hard-earned morsel; much in the same way that the white-headed eagle robs the osprey.

The general description of the plumage is as follows: the forehead and crown are dull yellowish white; the neck and sides of the head brownish white, speckled with black. Behind the eye is a streak of green; the breast is brown and the lower parts white, the back being covered with close zigzag lines. The tail is light brown; the wings are white and black, with green speculuin; the legs and feet dark brown.

In the female the breast is much lighter than in the male, and the back is a dark brown.

The Wood-duck (Aix sponsa) which is called also the "Summer duck" and "Tree duck" is not only one of the most beautiful of all its family, but is excelled in plumage by few of the feathered race. It obtains its name from its singular and characteristic habit of frequenting and building in forest trees, on the lofty branches of which, 
its sharp hooked claws enable it to sit and move about with perfect ease.

It is common enough in the neighbourhood of the Lakes of Upper Canada, and may constantly be seen during the summer months, darting noiselessly and swiftly through the water-side belts of wood, or ernerging from the hollow of some old gnarled trunk in which it has its nest; for it breeds throughout these districts as well as in many parts of the Lower Province.

Though they are sometimes seen in small flocks, I have myself only met with them either singly or in pairs; and it is a striking sight to watch them cleaving the air with the grace and speed of the hawk, and alighting suddenly on the branch of a tree. The first time I ever saw one, I was excessively astonished, never having heard of such a bird, and was divided between anxiety to obtain the specimen and reluctance to shoot anything so curious and beautiful.

The head of the male bird is ornamented by a pendent tuft of green, white and purple feathers, about two and a half inches in length, which he has the power of elevating: a fact which does not appear to be noticed by any naturalist. In the female this is merely a rudimentary crest. The bill, which is a reddish orange, is hooked; the sides of the head are white and purple; and a band of pure white encircles the neck. The 
back is a greenish bronze, the tail dark green; breast rich brown spotted with white; the wings blue, green, black, and silver-grey; and the under parts white, tinged with delicate violet. Many of these feathers are highly valued by artificial-fly makers.

The female, besides the above difference in the crest, is a smaller bird, though both are below the average size and weight of most ducks. She is less brilliant in the colouring of her plumage, and is also less careful of it than her mate, freely stripping her breast of its soft down to line her nest. She lays generally about a dozen eggs, which are of a rich cream colour and highly polished.

When the young are sufficiently fledged, the mother carries them in her bill, one by one, from their comparatively lofty nest to the water, in which they begin to swim about at once in search of food. From this time until they are able to fly they live among the reeds and long grass, carefully watched and defended by their parent.

The Wood-duck appears to be less dependent for food on aquatic productions than any other of its tribe; insects, seeds, grain, and acorns forming the most important part of its sustenance. The flesh is well flavoured, though not equal to that of the teal, and some others.

They breed during the months of May or June, 
according to the latitude they inhabit; and though common in Mexico and the most southern of the States of America, do not appear to venture further north than the latitude of Nova Scotia, leaving again in the beginning of winter for the warmer regions.

Though evidently unable to endure cold, it thrives in even tropical heat, and is found-as in Ceylon-within a very few degrees of the equator.

The Wood-duck is frequently domesticated in Canada and is very easily tamed. A more beautiful and interesting bird can hardly be found for such an object, and it is to be regretted that it is not more generally known and introduced on ornamental waters in private grounds, being perfectly hardy in every way.

We come now to the Fuligulino which principally frequent the sea coast or its vicinity, though many of them are scattered through the interior of the country, and found in the most remote lakes and inland waters. They differ from the foregoing or true ducks, in having the feet larger and the legs placed further back, and in being altogether more especially formed for swimming and diving. We may begin with the Scaup (Fulix marila) which is precisely similar in all respects to that of Europe, and like the latter feeds on shell-fish, sea-weeds of several kinds, young fry, and many other aquatic pickings, the greater part of which are obtained 
by diving. It frequents salt and fresh water indifferently, and is invariably in good condition at all seasons of the year, which circumstance is, however, a matter of small importance, seeing that its flesh is held in small esteem, on account of its coarseness and indifferent flavour.

The origin and meaning of the term Scaup have been variously accounted for, and we have no less than three different derivations given by as many naturalists, though that of Yarrell is no doubt the true one. He says,* "beds of oysters and mussels are in the north called 'oysterscawp' and 'mussel-scawp,' and from feeding on these shell-covered banks the bird has obtained the name of Scawp-duck."

The Scaup, or as it is generally called in America, the Blue-bill and Black-head, breeds a long way north. Its eggs are six or seven in number and of a pale chocolate colour, and are generally found either simply laid on the bare ground or but slightly raised from it, on what can only by courtesy be termed a nest.

The Scaup has a black head, neck, and breast, the former being glossed with green reflections. The back is mottled green, the wings are chiefly grey and white, the under parts are white and the tail brown. The bill, which is broad at the end, is of a light blue. 
In the female the darker parts are brown instead of black, and the bill is slate colour, as are also the legs and feet in both sexes.

The Scaup is a very difficult bird to get within range of, for though it only rises from the surface of the water slowly and with difficulty, on account of the shortness of its wings, it is extremely wary, and dives with extraordinary rapidity.

The Little Blue-bill (Fulix affinis) of Baird, the American Scaup of Yarrell and Audubon,* by whom it is correctly described as a distinct species of the above, was apparently unknown to Wilson, and is simply mentioned by Sir John Richardson $\dagger$ and other naturalists as a variety. The following are, however, remarkable points of difference between the two: the inferior size of the present bird as compared with the other; the lesser depth of its bill at the base, its smaller head, the darker colour of its legs and feet, and the deeper hue of the undulating mark on the back. The breast and under parts are mottled grey instead of being pure white; there is less grey on the former part, and the plumage of the head and neck are plumcoloured in place of black, as in the other. It is even more difficult to obtain a specimen of this than of the 
former, for while equally difficult of approach it is far less common.

The Ring-necked duck (Fulix collaris) I imagine to be the same bird as that called by Wilson the Tufted duck, in which name, however, he is evidently wrong, for the "Tufted duck" is not found in North America. Though the Ring-necked duck undoubtedly has a small tuft, it is principally distinguished by a ring or band of chestrut which encircles the neck about half-way up: a characteristic which is entirely wanting in the Tufted duck, properly so-called, of Europe and Asia.

The head of the Ring-necked duck is a glossy black with purple reflections; the bill broad and partially blue. The neck above and below the chestnut ring described is also black, as are the back and vent, the wings being brown. It is a small duck, but the flesh is very tender and excellent. It passes through Canada about the same time of the year as the generality of other ducks, but in fewer numbers.

The Canvas-back Duck (Aythya valisneria), so well known in this country as an article of luxury, is a species exclusively North American.

The excellence of flesh to which it owes its value and celebrity, is due in a great measure to the nature of its food during the autumn and winter months, which at that season consists chiefly of the Valisneria Americana, 
an aquatic plant growing in rather shallow and brackish waters within the influence of the tides, and having long narrow leaves growing to some height above the surface. The root is white, and its flavour is said to resemble that of celery. This, which is the only part of the plant eaten by the bird, it obtains by diving, and when abundant all other kinds of food are passed unheeded. So attractive is it, that wherever the plant is found, there the Canvas-back is sure to congregate; though the converse does not always hold good, as has been asserted. Flocks are frequently met with on parts of the coast where the plant does not exist, and they are then found to subsist on molluscæ, different marine plants, and algæ: a diet which generally deteriorates the flavour and delicacy of the flesh to a greater or less extent.

The most noted resorts of the Canvas-back have always been Chesapeake Bay, the mouths of the Potomac, and James River, with several other lesser streams and river mouths in the same quarter, all which abound with the valisneria. The recent warlike operations in those districts must however have completely driven away so shy a bird; and we may have to add to the other results of the late American war the scarcity, and inferiorityowing to its banishment to less favourable waters-of one of the most delicious birds known. 
As most persons are probably aware, the Canvas-back derives its name from the resemblance which the marking of the back bears in its appearance to that of canvas, being of a light grey, curiously covered with fine dusky lines closely intersecting one another like crossed threads.

This peculiarity occurs also in the common Pochard or Dun bird,* which being somewhat similar in many other respects (though not in flavour or delicacy) is often sold by London game-dealers as the genuine Canvas-back. The following points of difference, however, if attended to, would prevent any one from being so deceived. When in good condition the male Canvas-back weighs about three pounds, and the female about two pounds and three-quarters, while the pochard averages only one pound and three-quarters. The bill of the Canvas-back runs high up on the forehead, is perfectly black, and an inch longer than that of the Pochard; or three inches instead of two. In the latter it is also narrower and slighter, and generally of a slate colour, with black base and tip only. Further, the legs and feet of the Canvas-back are larger, and of a much paler ash colour than those of the other. There are likewise minor differences in the colour and markings of the plumage, 
but the above distinctions are sufficient to enable any person to tell the one from the other.

The following is the plumage of the Canvas-back. The forehead and cheeks are a dusky brown, all the rest of the head, as well as the neck, being of a bright chestnut. The upper portion of the breast is black, extending round to the canvas-like marking of the back, which has been already described. The lower plumage is white, marked somewhat similarly to the back, though more faintly, the sides being dusky freckled. The wing-coverts are grey speckled, the wing feathers slate colour, with a narrow edging of deep black on the inner ones; underneath the whole are white. The legs and feet, the latter of which are rather large in proportion to the size of the bird, are of a pale ash colour. The tail, which is short and sharp-pointed, is a brownish. roan, and the tail-coverts are black.

The female has the sides of the head and the throat of a buff colour, and in lieu of chestnut her neck is brown, which colour extends down to the breast and replaces the black of the male bird. In other respects there is no difference excepting in that of size as already noticed.

The Canvas-back appears in Canada, like nearly all sthe rest of the order, only at two periods of the year: in autumn, on its way south, and in spring, on its 
return. At these times, though it is a very shy and difficult bird to approach, a great many are killed on the lakes and rivers along their route, though of course nothing to be compared with the numbers killed at the great rendezvous along the Atlantic coast, where they are slaughtered merely as a matter of trade and without any regard to sport. Wilson gives the following description of some of the various modes practised to get within gunshot of them. "The most successful way is said to be decoying them to the shore by means of a dog, while the gunner lies closely concealed in a proper situation. The dog, if properly trained, plays backwards and forwards along the margin of the water, and the ducks, observing his manœurres, enticed perhaps by curiosity, gradually approach the shore, until they are sometimes within twenty or thirty yards of the spot where the gunner lies concealed, and from which he rakes them, first on the water and then as they rise. If the ducks seem diffcult to decoy, any glaring object, such as a red handkerchief, is fixed round the dog's middle or to his tail, and this rarely fails to attract them. Sometimes, by moonlight, the sportsman directs his skiff towards a flock whose position he has previously ascertained, keeping himself within the projecting shadow of wood, bank, or headland, and paddles along so silently and imperceptibly as * often to approach within fifteen or twenty yards of a 
flock of many thousands, arnong whom he generally makes great slaughter."

Their habit of thus collecting together towards evening, and of sleeping all night on the water, exposes them in an especial degree to this danger; but they generally abandon a neighbourhood where they have been fired into at night.

'They pass through Canada in great numbers on their flights north and south, and are mostly shot in the Detroit river and the St. Clair Flats, but are not so easily got at in the latter. The American Widgeon is almost invariably to be seen feeding in company with them, attracted also by the valisneria, as already explained.

The Red-headed Duck (Aythya Americana), called also the "Grey-back," very strongly resembles the Canvasback in general appearance, but on examination it will be seen that it has a shorter and broader bill, that the brown is absent on the head, and that the canvas-like markings on the back are much darker.

It is also very similar in appearance to the $F$. ferina of Yarrell above referred to, but is, I believe, a different bird altogether. It is found both on the sea-coast and on inland waters, and feeds chiefly at night. Its eggs are twelve in number and of a greenish white.

The Buffel-headed Duck (Bucephala albeola) is as ' common in the Gulf of St. Lawrence as on the inland lakes and rivers, and is generally seen in pairs. 
It is easily identified by the extraordinary and even marvellous quickness with which it dives at the slightest alarm.

On this account, as well as from its extremely rapid flight, it is not an easy bird to kill, and as the flesh is not remarkable for excellence the two facts together secure it a comparative immunity from destruction, so that it is very abundant.

The feathers of the head and upper portion of the neck are considerably inflated, and give these parts the appearance of being much larger than they are in reality; this and their somewhat woolly look have obtained for the bird the appellation of "Buffalo-head," of which Buffel-head is a corruption. The green and purple of these feathers is varied by a white patch behind the eye; the back is black, the wings black and white, and the breast and under parts pure white. The bill, legs, and feet are a bluish slate colour.

The Buffel-head breeds in the north of Canada, and up to much higher latitudes, and its nests are not unfrequently found in hollow trees by the water side.

An exceedingly pretty bird, though not superior to the above in a gastronomic point of view, is the Golden Eye (Bucephala Americana) which also frequents both salt and fresh water. It is a most active and vigorous ${ }^{\circ}$ bird, constantly diving and swimming about very rapidly, 
and when in the air flies with such force and velocity that the sound of its wings is heard at a great distance.

With all this apparent dash and boldness it is a very wary and cunning bird, and one of their number is invariably on sentry while the rest of the flock are feeding, so that they are not easily approached.

They do not migrate regularly at set seasons, like other ducks, but seem to move in a very partial and uncertain manner; and as they are evidently indifferent to the most rigorous winters, their migrations at these times would appear to be occasioned solely by the necessity of finding fresh feeding grounds.

The nest of the Golden Eye is found among rocks and stones, and even at times in the trunks of hollow trees, at some height from the ground. In this case the young must of course be carried by the mother to the water, as with the wood-duck already described. The eggs are about ten in number and perfectly white; they are generally covered over with down, which the female takes for that purpose from her own breast.

The plumage of the head and neck in the drake is green, with a violet gloss; a small but conspicuous patch of pure white near the bill has a singular appearance. The feathers on the crown of the head are lengthened into what may be called a crest, and the eye is a beautiful golden yellow, whence the bird's name. The lower 
portion of the neck, the breast and under parts are white. The back is nearly black, and the wings are prettily marked with black and white. The bill is black, deep at its base, and rather short.

In the female the bill is brown, lighter towards the tip; the head and upper part of the neck are also brown, with a ring or collar of white encircling the latter about the middle. The lower part of the neck and the back are ash-coloured, and the wings white and grey. The legs and toes in both sexes are orange, with the intervening membrane or web of a dark colour. The plumage of young males for the first few months of their existence resembles that of the female.

The Golden Eye is a winter visitor to Great Britain, and is well known in many parts of Europe, especially in the north. In Canada it is abundant on Green Island in October, and in the month of May congregates on Sixteen Island Lake in great numbers.

A still more beautiful bird than the above is the Harlequin Duck (Histrionicus torquatus) which is tolerably abundant on the northern coast of the Gulf of St. Lawrence, where it breeds on the low lands lying between the numerous fresh-water lakes that are met with a few miles inland. A few are found on the Restigouche, but its head-quarters are rather north of Canada.

Its neatly made and warmly lined nest is hidden in 
the long grass at a short distance from the water's edge, and the eggs are five or six in number, and of a very pale greenish white.

During incubation the female is left entirely alone, the males returning in flocks by themselves at that season to the salt water.

The Harlequin Duck is not only of excellent flesh and beautiful appearance, but is singularly as well as handsomely marked. The head and upper part of the neck are black, tinged with a bluish colour and purple reflections; the former having on either side two white patches of unequal size, the smaller behind the eye, the larger in front of it, ending in a semicircle of white and red that extends over the eye, and nearly meets a perpendicular line of white running down the neck. The lower part of the neck and the breast are curiously and very prettily encircled by two bands of white edged with black, the breast itself being a bluish ash colour. The sides are chestnut, and the back and wings nearly black, the latter marked with white. The bill is slate colour, with a reddish point, and the legs and feet are dark.

The female is much smaller than her mate, and of more sober plumage, its prevailing colour being a uniform brown. She has in addition to the two white spots on the side of the head a third one on the fore- 
head. The young males, as in some other species, resemble the females so closely in their colour and markings as to be with difficulty distinguished from them.

The Harlequin Duck has been met with in England, though more frequently in Scotland, and especially on its more northern shores; I have a specimen which was shot on the coast of Aberdeenshire, equal in beauty of plumage to any that I have ever seen.

The Long - tailed Duck (Harelda glacialis) inhabits principally the coast north of Labrador, and passes through Canada southward generally in November, though more irregularly than most other ducks.

It may be termed almost exclusively a marine bird, and its flesh is hard and fishy. The plumage, which is exceedingly pretty, varies very much at different seasons of the year and at different ages of the birds. Two long projecting black feathers in the tail of the drake are, however, always a distinguishing feature, and from them the bird's name is derived. The bill is black, with a deep yellow patch near its base. In the normal plumage the head is buff-coloured, and on either side of the throat, which is white, is a large spot of black, extending down the lower part of the neck. The back and breast are black; and the wings, which are chestnut and dark brown, are prettily covered by the drooping 
scapulars and tertials of pure white. Its eggs, five in number, have been described as of a dull chocolate colour; but are, according to Dr. Hall, a pale greenish-grey.

The Long-tailed Duck, which by the way, is common in the north of Scotland in the winter, bears a near affinity to the mergansers: a genus distinguished by their large body, and great length of head and bill, the latter of which, besides being rather pointed, is armed on both mandibles with saw-like teeth, and terminates in a hook curved downwards.

The Scoters, of which four kinds are found in Canada, feed on fish and large molluscs, and are rank and oily in flavour, and almost uneatable when killed. So strong is the flesh of the common Scoter that Yarrell says it is allowed by the Roman Catholics to be eaten in Lent, as being so completely identified with fish.

These birds have the bill rather elevated at the base, and the body large and bulky; and they fly heavily, and very close to the surface of the water.

The first, or common Scoter of North America, though named Oidemia Americana by Baird, appears to be precisely similar to the common Scoter of Europe (Oidemia nigra, of Yarrell), which according to that author, differs from every other species of the Anatidoe in having no bony enlargement of the trachea or windpipe: a singular and unaccountable peculiarity. 
The male is entirely black, the knob at the base of the bill alone being yellow: the female is of a brownish tinge. During the time of incubation the males associate in flocks together.

The Huron Scoter (Oidemia bimaculata) is a smaller bird than any of the other three. The upper plumage is a dead black; the breast and throat being a dark grey, and the under parts a lighter shade of grey. There are two white spots on the side of the head, and the wings are white and grey. The bill is a dark slate colour, and the legs and feet orange.

The Surf Scoter (Pelionetta perspicillata) Wilson considers to be peculiar to North America; and though Yarrell* and M'Gillivray $\dagger$ mention instances of specimens having been killed in England, Scotland, and the Orkney and Shetland Isles, as well as in other parts of Europe, these can I think, only be considered as exceptions; moreover it is always seen in America in large flocks, and never alone as in the irstances narrated.

The male is black, with the exception only of two white marks on the head, one on the forehead, the other behind the crown. The bill and legs are red.

The female is brownish black, and has little or no appearance of the enlargement on the base of the bill.

\footnotetext{
* British Birds, iii. 324. † Man. Brit. Orn., ii. 181.
} 
The Surf Scoter, or Surf Duck, as it is sometimes called, may be seen in the Gulf of St. Lawrence in great numbers, and generally in the stormiest weather, cresting the waves in evident enjoyment, but it is very difficult of approach.

The Velvet Scoter (Melanetta velvetina) which is precisely similar to that so well known on the eastern and northern coasts of Scotland during the winter months, is black, with a white band across the wing and a small white spot under the eye. The bill and legs are orange. The female is browner, and has more white feathers than the male.

The Eider (Somateria mollissima) is at times to be seen in considerable numbers on the north shore of the Gulf of St. Lawrence, but it breeds much further north.

Though generally known only as furnishing the valuable down which goes by its name, it is by no means to be despised on the table, notwithstanding that it is strictly a marine duck and is never met with inland.

Its habits, and the mode of procuring the celebrated down with which the nest is lined and filled, are too well known to need repetition. The plumage and appearance of the bird itself however may not be familiar to every sportsman who may have the luck to kill one, and may therefore be described, for there is a greater difference in appearance between the male and female of this species 
than is found in almost any other: so wide indeed, as frequently to lead to the belief that the two are different species or varieties.

The male is considerably larger than the fcmale, being a bird of upwards of six pounds' weight, and his bill, which is a dusky greenish yellow, runs up very far on the forehead. The top of the head is black, with a white streak, its sides light green, and cheeks white; the front of the neck is also white, as well as the back, the wingcoverts, and sides ; the breast, under parts, and tail being black. In short, with the exception of the two small green patches on the sides of the head, the whole plumage is black and white.

The female, on the contrary, is a reddish brown marked with streaks of a darker hue; the whole back is a dusky brown; and the bill does not extend so far up into the frontal plumage as in the male.

The legs and feet in both sexes are a dusky clouded yellow.

The Pied Duck or Labrador Duck (Camptolomus Labradorius) is common in the Gulf of St. Lawrence, and breeds on its northern shore, a short distance inland.

It derives its name from its magpie-like plumage; the head and throat being white, with a black stripe at the back of the head, and a band of black encircling the neck and extending over the back; while the rest 
of the plumage is alternate black and white. This characteristic is extended even to the bill and legs, the former being buff and black, and the latter white and black.

Its flesh is dry and fishy, and as an addition to the bag it is not worth shooting.

The Ruddy Duck (Erismatura rubida) Wilson says is extremely rare and an entirely new species, while Baird asserts it to be quite common; so that we may perhaps consider it ordinarily plentiful. I have only seen one specimen myself, and believe it to be very unequally distributed, which might account for the discrepancy between two such eminent authorities on American ornithology. It is found in the Gulf of St. Lawrence, and on many of the rivers flowing into it.

This is rather a small duck. The bill is blue and somewhat peculiar in form, being broad at the end, something like that of the Shoveller, and having the under mandible much narrower than the upper. The head is black, with a white patch on either side of it. The front of the neck, the back, the sides, and the tail-coverts, are a bright reddish-brown, from whence it has its name. The breast is covered with curious bristly feathers, of a grey hue striped with dark brown, the under parts being very similar in colour and marking, though the feathers are of the ordinary description. The wings are of a stone colour, and the tail black, and sharply pointed. 
The female is about the same size as the male, and has the same peculiar bill and sharp-pointed tail; but differs slightly in the colour of the plumage, the cheeks being buff, and the neck and breast a dull brown and grey; the under parts white, shaded with ash colour. The feet and legs are dusky in both.

The Smew (Mergellus albellus) is well known in our own country, and in the form of its bill, its general appearance, and habits, may be considered intermediate between the above sub-family and the mergansers, which follow. It is a handsome and beautifully marked bird, although simply black and white.

It breeds in the far north, and appears in the Gulf of St. Lawrence only in winter. It is a difficult bird to get near, but is of no value except to the naturalist or collector, the flesh being poor and fishy.

The Hooded Merganser (Lophodytes cucullatus) is also a very handsome bird, but its flesh is very little superior to that of the other.

This merganser, though an accidental visitor to England, is really a North American bird, breeding in the extreme north of that continent, and migrating to every part of it in winter; appearing rather to prefer inland waters to the sea. It has a beautiful crest of black and white feathers, which it has the power of elevating and depressing at will. The head, neck, and 
back are black, the wings barred with black and white, and prettily covered by the long drooping tertial feathers, which are black, with a white streak down the centre. There are two semicircular black marks on either side of the white breast, which have a very pretty effect. The under parts are white, and the sides covered with fine lines of black. The legs are flesh-coloured.

The female has also a crest, though she is smaller, and far less striking in size and marking. Her nest is more carefully made than is usual with the order generally, and contains six or eight white eggs.

The Red-breasted Merganser (Mergus serrator) is more common than the above, and appears to prefer fresh water to salt, though frequenting both.

The Goosander (Mergus Americanus) feeds on fish, and is very wary and difficult of approach, diving long before the shooter can get within range. To an ordinary observer, or one not acquainted with its habits, it appears to remain under water altogether; for it is cunning enough, when obliged to come up for air, to raise only its bill as far as the nostrils above the surface, so as to be all but invisible even in perfectly open water. When among grass or aquatic plants, which it always resorts to if practicable, it defies detection, owing to its singular faculty of keeping the body submerged close to the surface of the water. 
The Goosander is a handsome bird; but, like all the rest of the sub-family to which it belongs, has no culinary qualifications, the flesh being lean and fishy. It breeds in the north, and migrates in the autumn to the Southern States.

This bird affords another instance of the stupid misnomers bestowed by the Yankees on the animal creation of their country, where it goes by the name of the "Water Pheasant"!

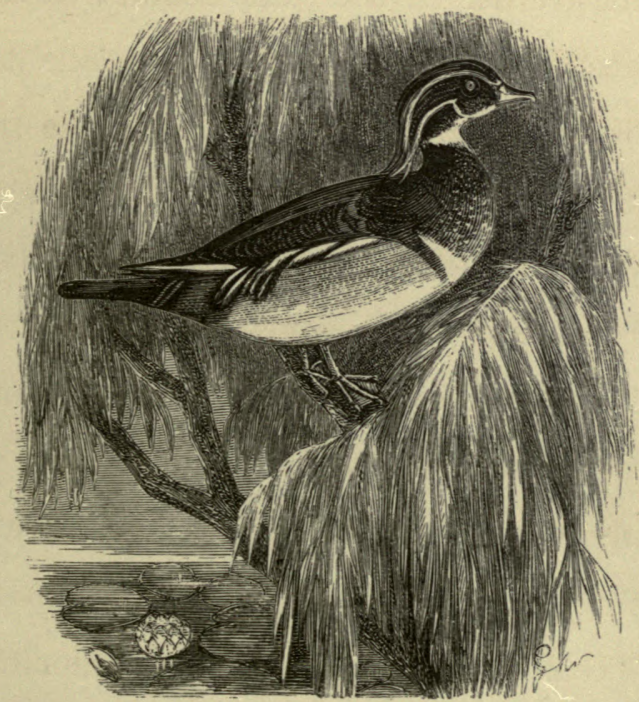

WOOD-DUCK. 

DIVISION III.

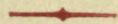

Jisłhes. 



\section{CHAPTER IX.}

ffistrories.

THE FISHERIES OF CANADA-IMPERFECTLY KNOWN IN THIS COUNTRYTHEIR GREAT EXTENT AND VALUE-NUMBER OF SALMON RIVERSLARGE TRADE IN DRIED AND SALTED FISH-EXPORTATION-IMMENSE TAKES-IMPORTANCE OF LESSER WATERS-VARIETY OF FISH IN THE LAKES AND RIVERS-FORMER GREATER ABUNDANCE-CAUSES OF the Diminution - Legislative PROtection - REVIVAL OF FISHERIES-CONSUMPTION OF DRIED EELS-TORCHLIGHT SPEARING. 



\section{CHAPTER IX.}

\section{dfishreries.}

THE inmense value and importance of the Fisheries 1 of Canada are very imperfectly known and insufficiently estimated in this country, for it is only few who have ever visited them, and fewer still who care to take either the time or trouble necessary to inform themselves on a subject of which the following is a mere outline.

In Upper Canada, the coast-line of the great lakes and the higher St. Lawrence, entirely excluding the smaller lakes and all tributary streams, is estimated at about 5000 miles in extent. In Lower Canada, the river and gulf of St. Lawrence alone add 1000 miles more of coast-fisheries for salmon, cod, mackerel, and herring, including upwards of seventy salmon rivers which are under the immediate care and protection of the Government; the whole affording employment to many hundreds of hands, and sustenance to thousands of inhabitants, while forming one of the most lucrative and important branches of trade in the country. 
From the Report of the Fisheries of the Upper Province it appears that a large portion of the fish taken on the east coast of Lake Huron, from Point Edward to Cape Hurd, including the Fishing Islands, is sent to the United States in barrels, and paid for partly in cash and partly in American goods. The fish taken at Point Edward, Goderich, Cape Rich, and Collingwood, is principally packed in boxes with ice and sent by rail to regular agents in Canada and the States, and is paid for in cash. The remainder and far greater portion, taken in Lake Superior, Georgian Bay, at the Duck, Manitoulin, Cockburn, and St. Joseph Islands, Mississisaugua Straits, and Sault Ste. Marie Rapids, in fact excepting only the Hudson Bay Stations and one or two others, is also sent to the States and paid for with American goods, paying no duties. A large quantity is also sold at the fishing stations to the captains of American schooners, and paid for with smuggled goods and whisky, threefourths of the fish taken in Canadian waters never entering a Canadian port.

From the Report of 1859 it appears that the Lake Huron Fisheries yielded in 1856 upwards of 27,037 barrels; or, at 120 fish to the barrel, 3,244,520 fish. The take in Lake Ontario is also equally abundant, and in some cases" has been even prodigious. In the above Report mention is made of 47,700 White-fish (nearly 400 
barrels) being taken two years previously at Wellington Beach at a single haul. At Burlington Beach, during 1856, 1,900,000 Herrings and 86,400 White-fish were taken. At Port Credit, 470,000 fish werc captured, two-thirds of them being Salmon, and at other fishing stations on Lake Ontario, 200,000 to 300,000 fish. The entire take for the year, according to the lowest estimate, amounting in value to $\$ 500,000$. Although as above stated all the less important lakes and streams are excluded from these Returns, their aggregate quota is an item of no inconsiderable importance to the inhabitants of the districts in which they are situated. In the Western Province the up-country lakes and their feeders are exceedingly numerous, and abound with fish of great variety. In the Eastern townships, which are the English-speaking portion of Lower Canada, lying south of the St. Lawrence and between the French country and the States, these minor waters are also as prolific as they are numerous.

The variety of fish inhabiting this vast extent of waters, which are for the most part of great depth and extraordinary clearness, is as great as their quantity is extraordinary, comprising, in addition to nearly all the fresh-water species of Great Britain, several altogether unknown in our country.

About thirty or five-and-thirty years ago most of the 
rivers in Upper Canada abounded with Salmon and other fish to an extent which we in this country can hardly conceive. Mr. McCuaig, writing from Hamilton, says, he himself saw salmon from 1812 to 1815 swarming the rivers so thickly, that they were thrown out with a shovel and even with the hand. But the ignorant destructiveness of one class, and the selfish cupidity of another; the erection of mill-dams which prevented salmon from ascending the rivers to spawn; the system of choking the streams with sawdust and refuse from the mills, of spearing by torchlight, of over-netting, and of fishing out of season, gradually produced their inevitable results. So serious became the prospects of the fisheries, that about eleven years ago the necessity for interference on the part of the Government, and for stringent legislative enactments, was brought by $\mathrm{Mr}$. Nettle, the present Superintendent of Crown Fisheries for Lower Canada, under the notice of the then Governor-General* (himself an ardent lover of salmon fishing), to whom both New Brunswick and Canada are much indebted for the interest he took in their fisheries. This eventually resulted in the passing of the present Fishery Act, prior to which there was no law or regulation on the subject. Every person fished when, where,

* Sir Edmund Head. 
and how he chose; and the principal rivers were in the hands of the Hudson's Bay Company, whose agents were continually embroiled in dispute and strife with other fishermen. Some idea of the extent to which over-fishing was carried, may be gathered from the fact that on one river alone no less than twelve thousand fathoms of net were found set, besides appliances for sweeping every pool of its upper waters. The Government, at the suggestion of Mr. Nettle, re-entered into possession of all the salmon rivers flowing through the Crown property-fisheries which each succeeding year will increase in value-and the existing system of "leave and licence" was thereupon organized: the former for the season, the latter for a term of years, the one applying to rivers, the other to fishing stations along the shores of the Gulf.

These measures were adopted not so much with a view to benefit the revenue as for the purposes of protection and increase, for the enforcement of which fishery overseers were subsequently appointed in each district.

The result of this system, the working of which has now been fairly tested, has been the complete preservation of the salmon fisheries from impending destruction, an increase in the take of fish of at least fifty per cent.; and a reduction of their price in a corresponding ratio, besides an addition to the revenue which far exceeds the whole expense of the supervision. 
In the lakes and rivers of the Upper Province fish of the most valuable kinds are now increasing perceptibly, while the salmon rivers of the Lower one, bid fair to surpass those of Scotland, and are yearly inviting over our countrymen in growing numbers.

Important and valuable as are the above fish, there is one which neither figures in the Returns nor attracts the lovers of the gentle craft, and yet deserves mention before proceeding to the higher groups, on account of its usefulness to a large class of Indians, habitans, and settlers, by whom it is taken in very great quantities. This is the "Longbec" or Common Eel (Anguilla vulgaris), which both when freshly caught or when dried forms a most important article of food in many parts of the country.

Though more generally taken in traps with fascine leaders, they are often speared by torchlight on a large scale, a sight which one evening in the month of July I had an opportunity of witnessing at Coteau-du-Lac on Lake St. Francis.

Darkness had barely descended when, as if by magic, the whole lake, which is twenty miles in length and six broad, was suddenly dotted over with bright flaming lights proceeding from the canoes engaged in spearing. The extraordinary number of these lights, and the vast space over which they were spread, produced a most strange and beautiful effect. 
The blazing torches of birch-bark in the nearer canoes, brightly illuminating the picturesque dress and and attitudes of the French Canadians that manned them, completed the picture. In each canoe were two men equipped in blue shirt and loose trousers, with Indian sash round the waist: one sitting in the bottom using a broad paddle, and the other standing upright, spear in hand, in a cranky little craft, which, even to sit in, requires as much skill and caution as a Cambridge outrigger.

After we had watched the scene for some time, the blue heaven with its glittering stars was quickly overspread with black angry clouds, a sighing wind moaned through the woods, followed by bright flashes of rosecoloured lightning, revealing for an instant the dark outlines of the swift canoes, which, with extinguished lights, were deserting the roughening waters, and leaving all in deeper darkness. The lake was soon covered with white breakers, and the low rumbling of the thunder grew louder, till it burst in terrific claps overhead. For an instant or two a distant rushing sound was heard, and then down came a perfect deluge of rain.

One is at first surprised that spearing could be carried on at all in a lake of dimensions which would lead one to suppose it of considerable depth; but on the "eel 
grounds," or flats, the water is not more than four or five feet deep, and these shallows occupy a very large portion of the lake; the main channel, which is about five fathoms in depth, being very narrow.

Though eels usually migrate twice in the year, that is, to and from the sea, wintering in the brackish water of its estuaries, and returning in early summer, they will live and breed perfectly well in inland lakes and rivers at a distance, or under circumstances rendering it impossible for them to have any access to the coast. Therefore it is not easy to determine the question, whether the eels of this lake and of the upper parts of the river St. Lawrence- of which there are more than one species-pass up and down the rapids which lie between them and the Gulf.

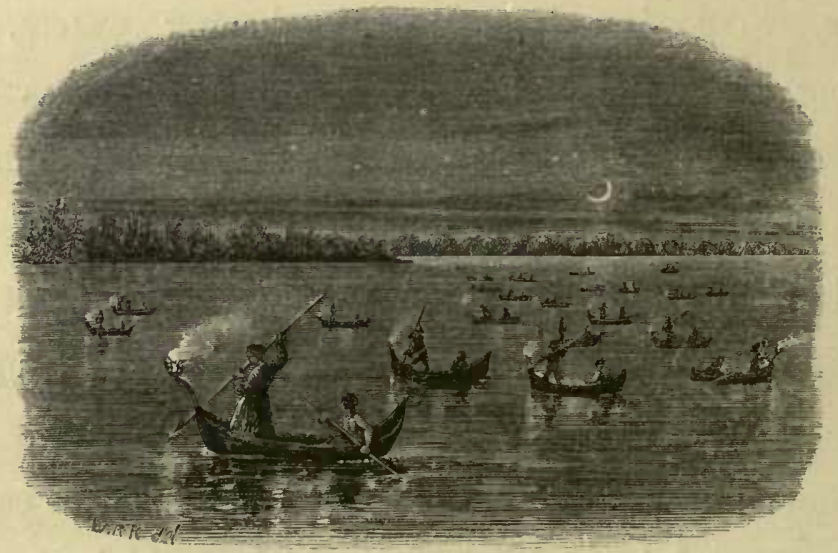

EEL SPEARING, LAKE S'T. FRANCIS. 
CHAPTER X.

\section{attalacopteri.}

THE SALMON-DISTANCE FOUND FROM SEA-ASCENT OF RAPIDS-BREEDING IN FRESH WATER-SCARCITY OF SALMON IN ONTARIO-IRREGULAR DISTRIBUTION - PREFERENCE OF SALMON FOR COLD RIVERS - PROPOSED RESTORATION OF RIVERS OF ONTARIO- "OPEN SEASON "-NO ROD-FISHING IN UPPER PROVINCE-FISHING LICENCES-RENTALS OF FISHERIES-GOVERNMENT MANAGEMENT OF RIVERS-HOW TAKENTHE JACQUES CARTIER-RIVERS NEAR QUEBEC-MODE OF REACHING LOWER SALMON STREAMS-SALMON FLIES-FISHERIES OF NORTHERN SHORE OF GULF - THE SAGUENAY AND TRIBUTARIES - PRINCIPAL SALMON RIVERS BELOW THE SAGUENAY-LISTS OF FISH KILLED IN THE GODBOUT AND MOISIE-SALMON RIVERS OF SOUTHERN SHOREGASPÉ DISTRICT-ITS RIVERS-SIZE OF FISH-THE TROUT-VARIATION OF COLOUR-INSTANCES OF TRANSFORMATION-FISHING SEASON -AVERAGE SIZE OF TROUT-TROUT NOT TO BE NETTED IN CANADA ARTIFICIAL FLIES-TROUT STREAMS IN NEIGHBOURHOOD OF QUEBEC -THE LAKE TROUT-ITS SLUGGISHNESS-THE MACKINAW TROUTPECULIAR TO NORTHERN LAKES-THE SEA TROUT-ARTIFICIAL FLY FOR-THE WHITE-FISH-PECULIAR TO NORTH AMERICA-DESCRIPTION OF-DELICIOUS FLESH-DIFFICULTY OF TRANSPORTING. 



\title{
CHA P T E R X.
}

\author{
ghooninales.
}

THOUGH rarely taken by the rod higher up the 1 St. Lawrence than the mouth of the river Ottawa, the true Salmon (Salmo salar) is netted as far inland as the western extremity of Lake Ontario, a distance from the open sea which may be roughly estimated at about a thousand miles.

In the case of small rivers, it is well known that Salmon generally wait in the vicinity of the mouth until the waters are sufficiently swollen by the rains, when they run up in great numbers, seldom resting in the pools along its course as long as the water continues in spate, their instinct teaching them to advance while it is possible to do so. In large rivers like the St. Lawrence, however, they run up in greater or less numbers almost daily throughout the usual season, entering it as soon as the ice begins to melt along the shores of the Gulf, which they usually leave with the reflux. The sooner the ice disappears from the river, therefore, the sooner the Salmon enter it. They are said to arrive in greater 
numbers as the wind and tide are stronger. It would be difficult to find a more interesting example of the wonderful instinct, perseverance, and strength for which the Salmon is noted, than this long and difficult journey, in which, stage after stage, they succeed in surmounting rapids, which man, with all his boasted skill and science, and the mighty aid of steam, is powerless to ascend.

The apparent impossibility of any living thing swimming up the rapids of the St. Lawrence led, not unnaturally, first to the conjecture and then to the belief, that the Salmon of Ontario must be entirely confined to the lake and its tributaries. The argument that these fish, when restricted solely to fresh water, cease to be reproductive, led in the same manner to the story of the existence of tracts of water in the lake itself so impregnated with salt springs as to obviate the necessity of the fish visiting the ocean. But the breeding of Salmon in fresh water, if not common, is at any rate a fact of ascertained occurrence. Scrope says, "It appears that salmon will live and even breed in fresh water without ever making a visit to the sea at all;" and in support of this opinion quotes Mr. Lloyd, who, in his work on "Field Sports of the North of Europe," says, "Near Katrineburg there is a valuable fishery for Salmon, ten or twelve thousand of these fish being taken annually. These salmon are bred in a lake, and in consequence of cataracts 
cannot have access to the sea." They are however, it must be added, small in size and inferior in flavour. Not long ago, an instance was published in the Field in which salmon smolts, after seven years' confinement in a freshwater pond near Bedale, were found full of ripe roe. As was remarked on this occasion, Salmon have been known to grow to six or seven pounds weight in other parts of our own country without visiting the sea; so that this convenient combination of salt and fresh water is not necessary in order to prove the permanent residence of the Ontario Salmon, and its existence-though fully believed in by many at this present moment-is in reality purely imaginary.

Another suggestion was that these fish were not salmon at all, but simply Bull-trout.* The difference, however, between the two is unmistakeable. In the latter the spots on the gill-covers are larger and more numerous than in the former; it has a greater number on the back and shoulders; the scales are proportionately smaller, and the teeth longer and more powerfully made; while the flesh is of a fainter pink and inferior flavour. There are other and more minute differences in the fins and in the form of the tail, as well as in the number of the vertebræ, which is one less than in the salar, or fifty-nine

* Salmo eriox. 
in place of sixty, so that it is not easy to confound the two fish.

Though Salmon fresh from the sea is found in Lake Ontario, and is taken with the gill-net at the Humber mouth, and occasionally even at the ultima thule of the bar of Hamilton Bay, as well as at. Bond Head and the mouths of the Credit and Trent (to the extent in all of between one and two hundred fish in the course of the season) it is never induced to take either fly or bait.

How fish travelling such distances are enabled to find their way back so unerringly to the waters they had left, is a marvel that can only be accounted for by supposing them to be endued with powers of memory sufficient to recal the various waymarks on their course.

The fact of their being more plentiful along the northern shore of the lake than the southern is attributed to the greater coldness of the streams entering on that side; but it is singular that the only river of either shore in which they are entirely unknown should be the one of greatest volume, in fact the chief tributary of the lake, namely, the Niagara: a river, too, not merely free from impurities and clear of all mill-dams and other obstructions, but of unusual clearness and transparency. Its strong current, deep abrupt sides, and want of shallows or gravelly beds suitable for spawning, are perhaps sufficient to account for fish not breeding there; 
but as it affords abundance of food, their marked absence is a negative corroboration of the truth of the propensity or habit attributed to them of always revisiting the place of their birth.

I am intimately acquainted with every part of the Niagara, from the bar up to the foot of the Falls, and have fished it, and been on it at all seasons of the year, but never saw or heard of a single parr, srnolt, grilse, or salmon being taken, or even seen in its waters.

With regard to their evident preference for the colder rivers, it is perhaps hardly necessary to mention the fact that a high temperature is fatal to the salmon, which has no power of resisting heat, and is indeed limited to countries lying north of the forty-first parallel of latitude. Dr. Davy's experiments proved that a continued temperature of eighty degrees is sufficient entirely to destroy the vitality of its ova. Injurious, however, as is the effect of heat, the most extreme cold seems to have no such effect, for the eggs may be packed in ice without danger.

It has been proposed, with a view to restoring the salmon to the rivers of Lake Ontario, which the spear of the savage, and the saw-mills and lumber establishments of civilized man, have almost destroyed, that two of the most suitable streams should be set apart as nurseries, in which netting should not be allowed: the rivers Credit and Moira being those recommended for the purpose. 
Were this carried out, and, as the Superintendent says, all the mill-dams removed, or fishways constructed adjacent to them, protection being also afforded to spawning fish, most of the rivers in this district would ere long be plentifully stocked with salmon once more. The complete removal of the standing weirs along the south side of the St. Lawrence, from St. Thomas Montmagny to Three Rivers is however a matter of equal importance, as there is no doubt they have hitherto greatly impeded fish ascending the river.

When the tributaries of Ontario again abound in salmon it will be interesting to know whether the Niagara continues to remain deserted by them.

The Canadian Salmon does not differ at all from ours either in form, flavour, or habits, and the two may be said to be identical, the salar being the only species of the Salmonidæ which is common to both the Old and New World.

The "open season" is from the 1st of March to the 1st of August, and though the period of fly-fishing extends to the 1st of September there is little sport to be had during the last fortnight; nor is it at its best earlier than the first week in June. At that time also the fish are in their highest condition, of which there is perhaps no better criterion than that of their colour, for it will invariably be found that the deeper the red of 
the flesh is, the greater is the proportion of curd or albuminous fat, as well of course as of the rich oil which contains the colouring matter.

From what has been said above it will be manifest that there is no salmon fishing to be had with the rod in Ontario or its feeders, nor indeed is there any to be found above Quebec, except in the Jacques Cartier, which is not far from it, and the intending fisher should lose no time in shaping his course towards that ancient city, which commands all the salmon fishing of the country.

Though I shall ever regard the sail down the St. Lawrence as one of the most enjoyable reminiscences of my sojourn in Canada, it is not necessary here to describe the lovely "Lake of the Thousand Isles," reflecting on its glossy surface the grey rocks, sombre pines, and waving foliage of the countless islets, which, of every size and form, stud the glassy stream for miles; nor the glorious Rapids, down which the passive steamer is borne like a dancing straw on the headlong rush of waters; the calm beauty of Lake St. Louis; Montreal, with its bright tin roofs and spires; or the first view of the farfamed citadel of Quebec on its lofty eminence.

Arrived in this city, it is only necessary to go to the Crown Lands Office in order to get leave to fish, and obtain all requisite information on the subject. A 
licence is either granted for some river specially named therein, or carte blanche is given to fish in all or any that may not be let already.

The rentals vary from $\$ 50$ to $\$ 400$ per annum, the fish taken being of course the property of the lessees, the generality of whom preserve their surplus take, by salting, smoking, or pickling. The rivers are usually leased for periods of five years, and are divided into netfishings and fly-fishings, no net being allowed above tidal water. The Government exercises the sole right of management, and keeps all the rivers in its own hands, so that there are no conflicting interests to contend with, as must be the case whenever there are proprietors of upper and lower waters.

Many resident gentlemen rent rivers and make their own party each succeeding year, according to the size of the river and the state of the fishing, which is of course very much affected by the depth of water in different seasons. In arrangements of this nature the expenses of rent, catering, boat-hire, and attendants, is divided among the party, and this is not only the most congenial mode of procedure, but has the additional advantage of considerably lessening the cost. Other rivers are rented by English sportsmen.

The Jacques Cartier, a glorious morning's drive from Quebec, is a lovely and picturesque river, abounding in 
beautiful pools and rapids. At Dery's bridge, which is the general rendezvous of amateur fishermen, and about twelve miles from the mouth of the river, is a fall of about ten feet in a narrow gorge, at the bottom of which is a fine pool in which the fish congregate before ascending.

There are other salmon streams within easy reach of the city, as the St. Anne, St. Charles, Port Neuf, \&c.; but being on that account a good deal frequented, it is better to proceed at once to some of the rivers below, where one may revel in unfished pools and the undisturbed enjoyment of wild life. Formerly, and indeed till very lately, the only way of reaching these rivers was by means of a pilot boat or fishing smack: a mode of transport still preferred by many, and in fact indispensable for getting access to the more remote rivers. These boats are always to be hired at Quebec, either by the month or by the week, crew and all; or a simple passage may be negotiated for to any particular point. The chief drawback attending sailing boats, namely, the uncertainty of reaching one's destination in a given time, is greatly aggravated in the Gulf of St. Lawrence: the dead calms and contrary winds which seem always to prevail there at this period of the year, frequently detaining the impatient passenger a prisoner on board his boat for many days together in the height of the fishing-season. 
A more convenient and certain passage is afforded by the Government steamers, which in the beginning of June take the half-yearly supplies and stores to the different lighthouses in the Gulf, and will convey the holders of licences to the mouth of any river on which they may have taken fishings. Coming back is however a matter of more uncertainty, though at most of the rivers it is generally possible to find some schooner or other vessel in which a passage may be obtained to Quebec. The Ste. Marguerite is easily reached by steamer twice a week from Quebec, as are also the Gaspé rivers on the opposite shore.

It is of course necessary to be well provided with everything for the bivouac, not forgetting a small tent, though on many of the principal rivers sheds of bark will be found, which have been erected by former fishermen and repaired from time to time by their successors.

As to the kind of flies best adapted to these rivers, medium-sized ones, with bright brown or claret bodies are as a general rule the most killing. The following, taken by permission from Mr. Nettle's book, are known and tried flies, and no one can do wrong in providing himself with any or all of them.

"No. 1. Drake wing; fiery red mohair body; red and claret hackle mixed; twist of green peacock herl; antennæ same as wing. 
"No. 2. Grey mallard wing; orange body, gold tinsel and ginger hackle. Same with black hackle very good.

"No. 3. Grey mallard wing; body, dark green; black hackle, silver tinsel.

"No. 4. Grey duck wing; body, grey; ginger hackle, silver twist, antenæ same as wing.

"No. 5. Dark turkey wing; yellowish brown body; red hackle; peacock's herl and head; antennæ, green peacock herl.

"No. 6. Mallard wing; dark green body, turkey's green and brown herl intermixed, tipped with red; antennæ black.

"No. 7. Grey turkey wing; body, straw coloured; black hackle, silver tinsel; antennæ, long, straw coloured.

"No. 8. Wing, turkey, or mallard and bustard mixed; claret and orange mohair body; black hackle, gold tinsel.

"No.9. Wing, English jay; distended lightish green body; silver tinsel, black hackle; antennæ, green peacock herl.

"No. 10. Wing, grey goose; body, claret, tipped with red; a twist of peacock's green herl; black hackle; antennæ, thin herl of peacock green.

"No. 11. Wing, grey goose; body, peacock's green herl and yellow tip, black hackle; body large.

"No. 12. The 'Nettle fly.' Wing, brown bittern; body, yellowish brown mohair; red hackle ; twist of peacock's green herl around the body ; antennæ same as wing." 
To this list I must add, what is perhaps of all others the best and most generally successful, viz., the "Saturday:" a fly tried to perfection by Alexander MacKenzie, Inverness, who is well acquainted by personal experience with the salmon fishing of Canada. The body of the "Saturday" may be either red, blue, green, or black, or of a very favourite brown, which is best described as a cow-dung colour, with a twist of red at the shoulder. The wings are double, one pair of golden pheasant topping, and the other having one side of mallard and the other of teal or wood duck. A very small golden pheasant neckfeather is laid flat over the wings, to which is added a pair of antennæ of blue and yellow macaw. A pair of blue kingfisher feathers is sometimes considered an improvement.

The northern shore of the St. Lawrence is divided by the Superintendent of Fisheries into the following districts, viz. : from the St. Anne River to the St. Charles; from the St. Charles River to Murray Bay; from Murray Bay to the Saguenay; the Saguenay River and its tributaries; and from the Saguenay mouth to Ance au Sablon.

There are several good salmon streams above the Saguenay, and that river itself, which is an outlet of Lake St. John, a hundred and fifty miles up country, and one of the wildest and grandest rivers imaginable, 
has many tributaries which abound in salmon, the principal one being the Ste. Marguerite, in which thirty fish a day may be taken by a single rod, but unfortunately these waters are now let on a long lease. It is a curious fact that no salmon are found in the main stream, although it is one of the largest rivers flowing into the Gulf.

The best and most important salmon rivers lie below Saguenay mouth, and are as follows: the St. Pancras, Misissiquihak, the Grand and Petite Bergeronne, the Escoumins, Portneuf, Blanch, the lovely Bersimis (now given up to the Indians), the Papinachois, Outardes, Manacouagan, St. Austin, Manitou (or "Great Spirit"), the Godbout, Trinity, Pentecost, Ste. Marguerite en bas, the Moisie, Trout, St. John's, the Mingan (fished by Prince Alfred), the Natashquan, the Musquarroo, the Esquimaux, and lower part of the Netagamu. In such a variety of rivers it may be well imagined that every kind of ground is encountered, trying the piscatorial skill, and the bodily energy, of the most experienced fishermen, and presenting a succession of truly beautiful scenery: the soft and picturesque as well as the wild and grand.

Sometimes the banks are clothed with dense wood, so close to the water's edge that it is necessary either to force a passage through the tangled forest, or, at the risk of being swept away by the rapid current, to leap from 
rock to rock in mid-stream. There lies a sunny gravelly reach, here a dark circling pool teeming with rising fish, while foaming waterfalls, sombre woods, bright open glades, and still sweeps that lie eddying and darkling below bold rugged cliffs, meet the eye at every point, rousing to admiration even the most stolid mind.

The coast is for the most part stern and wild, and except at the mouths of the rivers, where a few dwellings are generally clustered, is uninhabited. The interior, and indeed even at a comparatively short distance inland, is almost an unknown country, being trodden only by a few wandering Indians, or the trappers of the Hudson's Bay Company in the hunting season, and can be but little altered in its aspect from the days when it was first visited by the Norsemen and Icelanders under Biom Heriolfson eight hundred years ago.

On these tenantless banks, where the splash of leaping salmon is often the only sound of life that breaks the stillness, the anglers form their bivouac after their day's sport; and stretched on the greensward enjoy their evening meal, followed by the musquito-dispelling clouds of the fragrant weed, literally the "pipe of peace," (for without it there is none). As the shades of evening descend on the surrounding forest the night-hawk* commences its wild evo-

* Caprimulgus popetue. 
lutions, and the murmur of the river, and the plaintive cry of distant waterfowl soothe the mind into a state of tranquil repose unknown to the denizen of the busy world.

A fair idea of the sport to be had in some of the best rivers may be gathered from the averages on the following pages, for 1862 and 1863, in the Godbout.

This river is also let at the present time, as well as the Moisie, but there are abundance of good rivers still available to the visitor.

The following is a list of salmon killed by Lieut.Colonel Drummond Hay, late 42nd Highlanders, at the first Rapids on the Moisie river, at the end of July and in the beginning of August, in the space of a single fortnight, to his own rod.

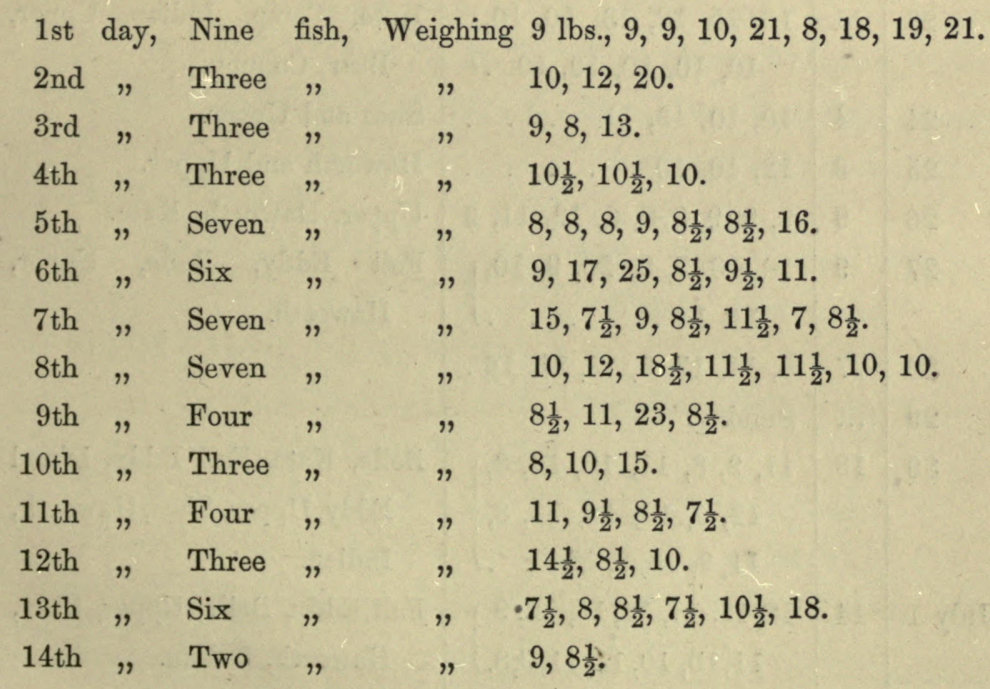

In all, 67 fish, weighing $754 \frac{1}{2} \mathrm{lbs}$. 
Salmon taken with the Fly by Three Rods in the River Godbout,

During June AND JuLy, 1862.

\begin{tabular}{|c|c|c|c|}
\hline DATES. & FISH & WEIGHTS. & PLACE AND OBSERVATIONS. \\
\hline ne 1 & 2 & $6,11 \cdot \cdot$. & Glassy ; one a Kelt. \\
\hline & 3 & . . . . & Kate, Belle; one a Kelt. \\
\hline & ... & Sunday. & \\
\hline & 9 & $\left.\begin{array}{c}10,14,17,8,10,10 \\
11,10,10 .\end{array}\right\}$ & Glassy, Belle, Kate and Camp. \\
\hline & 5 & $11,13,8,8,11$. & Belle, Shea, Indian. \\
\hline & 4 & $21,18,16,11$ & Camp, Belle, Indian. \\
\hline & 10 & $\left.\begin{array}{c}7,8,10,21,7,7,9,9 \\
11,15 . . .\end{array}\right\}$ & Camp, Elbow and Upper Pool. \\
\hline & 5 & $14,11,11,8,19$. & Glassy, Shea, Kate, Indian. \\
\hline & 5 & $20,11,21,9,9$. . . & Shea, Elbow, Cayley's Stone. \\
\hline & $\cdots$ & Sunday. & \\
\hline 2 & 11 & $\left.\begin{array}{c}18,15,18,13,10,10 \\
10,10,10,10,10\end{array}\right\}$ & $\begin{array}{l}\text { Kate, Camp, Indian, Upper, } \\
\text { Bear, Connop. }\end{array}$ \\
\hline 2 & 4 & $10,10,13,11$ & Shea and Upper. \\
\hline$?$ & 3 & $12,10,10 \ldots$ & Haworth and Upper. \\
\hline 2 & 9 & $9,9,9,9,8,6,19,11,9$ & Upper, Haworth, Kate. \\
\hline 27 & 9 & $\left.\begin{array}{c}13,13,7,9,20,9,10 \\
11,14 . .\end{array}\right\}$ & $\begin{array}{l}\text { Fall Eddy, Belle, Upper, } \\
\text { Haworth. }\end{array}$ \\
\hline 2 & 7 & $8,11,17,9,19,11,16$ & \\
\hline 2 & $\cdots$ & $\mathrm{S}$ & \\
\hline 30 & 18 & $\left.\begin{array}{c}11,9,8,11,10,12,8 \\
12,9,19,16,11,8 \\
11,9,13,9,12\end{array}\right\}$ & $\begin{array}{l}\text { Belle, Kate, Fall Eddy, Island } \\
\text { Eddy, Upper, Shea, Haworth, } \\
\text { Indian. }\end{array}$ \\
\hline July & 14 & $\left.\begin{array}{r}12,11,11,11,16,12,9 \\
11,10,10,11,11,9,8 .\end{array}\right\}$ & $\begin{array}{l}\text { Fall Eddy, Belle, Upper, Shea, } \\
\text { Haworth, Indian. }\end{array}$ \\
\hline 2 & 6 & $12,9,4,13,10,10$ & $\begin{array}{l}\text { River rising; Haworth, Shea, } \\
\text { Belle, Eagle, Charteris. }\end{array}$ \\
\hline
\end{tabular}


JUNE AND JULY, 1862-continued.

\begin{tabular}{|c|c|c|c|}
\hline DATES. & $\begin{array}{l}\text { NO. OF } \\
\text { FISH. }\end{array}$ & WEIGHTS. & PLACE AND OBSER \\
\hline 3 & 14 & $\left.\begin{array}{r}13,10,10,9,11,18,7 \\
10,12,11,12,9,10 \\
11 . . .\end{array}\right\}$ & $\begin{array}{l}\text { Glassy, Island Eddy, Belle, } \\
\text { Upper, Shea, Haworth, In- } \\
\text { dian. }\end{array}$ \\
\hline 4 & 6 & $10,10,10,10,10,10$ & Belle, Upper, Eagle. \\
\hline 5 & 20 & $\left.\begin{array}{c}9,13,16,17,8,11,19 \\
10,16,10,9,9,9,8 \\
10,10,10,10,11,9\end{array}\right\}$ & $\begin{array}{l}\text { Upper, Shea, Haworth, Indian, } \\
\text { Connop. }\end{array}$ \\
\hline 6 & ... & Sun & \\
\hline 7 & 18 & $\left.\begin{array}{c}10,10,12,10,10,10 \\
10,9,13,5,8,8,10 \\
12,10,10,9,11\end{array}\right\}$ & $\begin{array}{l}\text { Shea, Indian, Kate, Eddy, } \\
\text { Upper Pool. }\end{array}$ \\
\hline 8 & 17 & $\left.\begin{array}{r}9,9,10,4,10,11,11 \\
21,12,10,12,9,10 \\
10,13,12,9 .\end{array}\right\}$ & $\begin{array}{l}\text { Island Eddy, Haworth, Indian, } \\
\text { Connop, Upper. }\end{array}$ \\
\hline 9 & 4 & $10,10,11,10$ & Shea, Upper. \\
\hline 10 & 12 & $\left.\begin{array}{r}11,12,9,12,10,10 \\
10,10,10,10,9,12\end{array}\right\}$ & $\begin{array}{l}\text { Eddies, Shea, Indian, Connop } \\
\text { and Upper. }\end{array}$ \\
\hline 11 & 8 & $13,12,20$ & Shea, Haworth, Indian, Upper. \\
\hline 12 & 11 & $\left.\begin{array}{l}10,13,9,11,10,12,4, \\
9,10,19,8 .\end{array}\right\}$ & $\begin{array}{c}\text { Shea, Haworth, Indian, Upper } \\
\text { torrents of rain, river rising. }\end{array}$ \\
\hline 14 & 10 & $\left.\begin{array}{c}12,10,11,11,4,10,10 \\
10,11,8 .\end{array}\right\}$ & $\begin{array}{l}\text { Belle, Shea, Indian, Connop, } \\
\text { Upper; River rising. }\end{array}$ \\
\hline 15 & 17 & $\left.\begin{array}{r}11,11,10,10,11,11 \\
9,6,10,11,11,11 \\
8,11,10,10,10\end{array}\right\}$ & Shea, Belle, Fall, Glassy, Upper. \\
\hline 16 & 5 & $9,11,11,17,9$ & Shea; Storm and rain. \\
\hline 17 & 5 & $9,12,12,1010$. . & Belle, Upper, Eagle. \\
\hline 18 & 8 & $\left.\begin{array}{c}12,13,11,11,4,4,8 \\
10 . .\end{array}\right\}$ & $\begin{array}{l}\text { Upper, Eagle, Indian, Ha- } \\
\text { worth; two Grilse. }\end{array}$ \\
\hline
\end{tabular}

Total number of fish . . . . 279

Total weight . . . . . . $3116 \mathrm{lbs}$.

Average weight . . . . . $11 \frac{1}{4} \mathrm{lbs}$. 
Salmon taken with the Fly by Three Rods in the River Godbout,

During June and July, 1863.

\begin{tabular}{|c|c|c|c|}
\hline DATES. & $\begin{array}{l}\text { No.oF } \\
\text { FISE. }\end{array}$ & WEIGHTS. & PLACR AND OBSERVATIONS. \\
\hline June 8 & 1 & 8 lbs. . . . . . & Cayley's Stone. \\
\hline 9 & 1 & $16 . . . .$. & Sandbank. \\
\hline 10 & 2 & 8,10 . . . . . . . & Bear and Camp. \\
\hline 11 & 1 & $9 . . . . . .$. & Camp. \\
\hline 15 & 3 & $13,9,9 . \quad . \quad . \quad . \quad$. & Bear and Glassy. \\
\hline 16 & 2 & 21,10 . . . . . . & Fall, Bear. \\
\hline 17 & 4 & $24,12,9,9$. . . . & Eddy, Belle, Cayley. \\
\hline 18 & 8 & $\left.\begin{array}{c}11,10,10,13,13,10 \\
7,10\end{array}\right\}$ & Glassy, Belle. \\
\hline 19 & 2 & $9,9 . . . .$. & Camp, Glassy. \\
\hline 20 & 3 & $10,11,12$. . . . & Camp, Cayley. \\
\hline 21 & ... & Sunday. & \\
\hline 22 & 6 & $26,18,12,12,11,12$ & Kate, Belle, Upper, Bear. \\
\hline 23 & 5 & $22,8,10,10,24 \cdot \cdot\{$ & $\begin{array}{l}\text { Belle, Glassy, Kate, Upper, } \\
\text { Cayley. }\end{array}$ \\
\hline 24 & 6 & $24,12,13,12,12,11$. & Fall, Belle, Upper. \\
\hline 25 & 7 & $12,12,12,14,11,11,8$ & Cayley, Shea, Upper. \\
\hline 26 & 10 & $\left.\begin{array}{c}14,12,14,9,11,9,8, \\
12,10,9 .\end{array}\right\}$ & $\begin{array}{l}\text { Doctor, Indian, Kate, Bear, } \\
\text { Cayley, Upper. }\end{array}$ \\
\hline 27 & 17 & $\left.\begin{array}{r}13,12,15,12,13,12 \\
11,12,24,10,9,12 \\
12,14,10,10,9\end{array}\right\}$ & $\begin{array}{l}\text { Kate, Belle, four in Haworth, } \\
\text { Upper. }\end{array}$ \\
\hline 28 & ... & Sunday. & \\
\hline 29 & 12 & $\left.\begin{array}{c}12,9,13,9,10,8,10 \\
11,9,9,12,8\end{array}\right\}$ & Upper, Shea, Haworth. \\
\hline 30 & 8 & $\left.\begin{array}{c}12,11,9,8,12,10,13, \\
14 . . .\end{array}\right\}$ & Belle, Upper, Haworth, Indian. \\
\hline July 1 & 9 & $\left.\begin{array}{c}11,12,13,12,12,11 \\
11,13,11 .\end{array}\right\}$ & Shea, Upper. \\
\hline
\end{tabular}


JUNE AND JULY, 1863-continued.

\begin{tabular}{|c|c|c|c|}
\hline DATES. & $\begin{array}{c}\text { No. OF } \\
\text { FISH. }\end{array}$ & WEIGHTS. & PLACE AND OBSERVATIONS. \\
\hline July 2 & 8 & $\left.\begin{array}{c}12,12,24,13,10,9, \\
13,12 \mathrm{lbs} .\end{array}\right\}$ & Indian, Upper. \\
\hline 3 & 7 & $12,12,10,10,11,10,10$ & Fall, Upper, Haworth. \\
\hline 4 & 12 & $\left.\begin{array}{c}12,11,9,9,10,12,10 \\
10,9,8,10,12\end{array}\right\}$ & Upper, Belle, Shea. \\
\hline 5 & $\cdots$ & Sunday. & \\
\hline 6 & 5 & $11,11,10,12,8$ & Upper. \\
\hline 7 & 2 & $11,10 \ldots . .$. & Haworth, Upper. \\
\hline 8 & ... & $\begin{array}{l}\text { Thunder and rain, fish } \\
\text { down. }\end{array}$ & \\
\hline 9 & 5 & $13,11,13,9,9$ & Upper, Shea. \\
\hline 10 & 3 & $8,12,8 \ldots$ & Indian, Upper. \\
\hline 11 & 9 & $\left.\begin{array}{c}4,8,10,12,14,14,10 \\
10,9\end{array}\right\}$ & Upper: \\
\hline 12 & $\cdots$ & Sunday. & 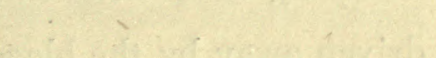 \\
\hline 13 & 7 & $11,10,8,11,9,12,9$ & Upper, Haworth. \\
\hline 14 & 4 & $14,10,16,12$. . . & Upper, Haworth, Indian, Shea. \\
\hline 15 & 4 & $7,10,12,12$ & Haworth, Indian, Upper. \\
\hline 16 & 3 & $14,12,10 \ldots$ & Upper, Belle. \\
\hline 17 & 1 & $6 . \cdot . \cdot . \cdot$. & Upper. \\
\hline 18 & 2 & $12,8 \quad \cdots \quad . \quad . \quad$. & Indian, Upper. \\
\hline 19 & $\cdots$ & Sunday. & \\
\hline 20 & 3 & $12,7,10 \quad$. . . . . . & Upper ) \\
\hline 21 & 2 & $10,8 .: \quad . \quad$. & $"$ \\
\hline 22 & 2 & $12,9 \quad . \quad . \quad . \quad$. & rising. \\
\hline 23 & 1 & $10 \cdot . \cdot .$. & Shea \\
\hline 24 & 5 & $13,5,21,11,4$. & Fall, Eddy, Haworth, Upper. \\
\hline 25 & & & \\
\hline 26 & ... & Sunday. & \\
\hline 27 & 1 & $12 \cdot \cdot \cdot \cdot \cdot \cdot$ & Shea. \\
\hline 28 & 1 & $8 . \cdot . \cdot . \cdot .$. & Upper. \\
\hline
\end{tabular}

Total number of fish . . . . . . 194

Total weight . . . . . . 2,190 lbs.

Average weight . . . . . $11 \frac{1}{\mathrm{~g}} \mathrm{lbs}$. 
Though similar lists might be multiplied to almost any extent, the above are sufficient to illustrate the nature of the sport, and with these practical results before one, it is only necessary to add that equally good fishing is to be had in many of the rivers before mentioned, and in some of them even better; though much injury has been caused in several instances by Yankees, who have been in the habit of coming, as I am informed, regularly each season, and setting their nets by force in preserved and protected waters. In other waters equal injury has been done by the Indians, whose inveterate habit of leistering does incalculable mischief; far more fish being driven away by the blood-stained water than are mangled by the cruel spear. No amount of supervision will effectually prevent this practice, so long as these poachers continue to find a ready sale for their fish among the small traders in the remote districts.

The rivers on the southern shore cannot be better described than in Mr. Nettle's*. own words.

"Approaching the eastern shores and rivers of the county of Rimouski, are the following rivers: the Rimouski, which is formed by the confluence of two tributaries, and is a river of considerable size; the Great and Little Metis, the Tartigo, Blanche, Matane,

* Nettle's " Fisheries of the St. Lawrence." 
and Chatte: all with extensive and valuable salmon fisheries.

The whole of the Gaspe district is intersected by numerous and splendid rivers, the principal of which are the St. Anne, the Magdalene, York, St. John's, Malbaie, Grand River, and the Great and Little Pabos. These rivers receive many valuable tributaries, and are all more or less noted for their vast quantities of fish, but the fact of there being a direct steamboat communication between Quebec and Gaspé causes rather too great an influx of fishermen.

In the Bay of Chaleurs are the Grand Bonaventure, the Great and Little Nouvelle, and the Great and Little Cascapediac; and ascending the Restigouche-which is a noble stream abounding with rapids and flowing for two hundred miles through a beautiful and picturesque country,-are the Matapediac, Patapediac, Mistouche, and other tributaries on the Canadian side, which teem with salmon. Formerly much larger fish were taken than now. A few years ago a salmon was taken in this district, measuring four feet eight inches in length. Thirty and forty pounds was not an uncommon weight, and instances have occurred of the capture of salmon weighing sixty pounds. Now the average is from twelve to fifteen pounds."

Several of the tributary streams entering on the 
opposite bank of this magnificent river abound equally in salmon, but as the Restigouche is the boundary of Canada, I must leave the rivers of New Brunswick to others to describe.

The rivers and lakes of both provinces abound in a Trout (Salmo fontinalis) so similar to the common trout of our own streams, that I am rather inclined to consider it a variety than specifically different.

They have been considered by some as a more inactive fish, and as affording less sport to the angler than ours, but the readiness with which they take the fly varies in different streams, this propensity being, as is well known to fishermen, as much affected by the nature of the waters they frequent as their colour is. In very dark still rivers they are often so sluggish that it is difficult to induce them to rise; a sombre tinge also pervades the body and their hues are wanting in brilliancy. In other streams, which, though equally dark, are rapid, the fish, while retaining the same dull appearance, are more lively; but in clear pebbly, sunny, swift rivers, especially if affording abundance of insect food, they combine the most brilliant hues and silvery brightness with the highest degree of activity.

It is well known in Scotland that moss-water dulls and deepens the tints, as in the so-called "bog-trout;" and the following instance mentioned by Lord Home shows 
that one and the same fish may go through all these changes of appearance in succession, according to the water it inhabits at the time. He says, "when fishing in the height of the season for trout in the Tweed, it has often happened, that out of two or three dozen I have caught, there should be five or six, differing not only from the common trout, but from each other. These trout come down into the Tweed during winter and spring floods from its different feeders, viz., the Ettrick, Yarrow, Jed, Trale, Eden, Leet, \&c., all differing completely from each other. These trout retain enough of their original appearance to distinguish them from Tweed trout, but after a few months' stay they gradually lose their original marks, and excellence of flavour, and become like the common Tweed trout in every respect. There can be no doubt that the nature of the soil through which the different streams flow is the cause of the difference of appearance, not only as to colour and size, but also particularly in the superior excellence of their flesh to that of the Tweed trout. I have also ascertained that the Tweed trout after having been a month or two in the Leet change their colour and assume the appearance of those of the Leet; while again, not only the Leet trout, but those of the other small burns, soon lose their beauty and other good qualities after they have been any time in the Tweed. I may mention that the food in the two little 
rivers Leet and Eden afforded the trout, is in my opinion the principal cause of their superior size and excellence. This food consists of small shells, cadis-bait, and clouds of flies."

These chameleon-like transformations are not, however, always so rapid as in the above cases: in many waters the change is much more gradual. Sir Humphrey Davy, for example, in his "Salmonia," mentions an instance in which trout, from a lake in Scotland, remarkable for their deep red flesh, being introduced into another lake where the trout had only white flesh, retained their peculiar redness for many years. They appear to have all associated together in spawning in the burn which fed the lake, those newly introduced being easily known by their darker backs and brighter sides; but by degrees, from the influence of food and other causes, the change gradually commenced, the young fry of the imported variety were less red in flesh than the parent fish, but not till about twenty years had elapsed was the variety entirely lost. Similar variations and changes are incidental to trout in every part of the world where they are known, and those of Canada are no exception to the rule.

The spawning time, though varying a little between the extremes of the two Provinces, is about September, and the young fry make their appearance in the shallows 
and smaller streams in early spring. The fishing season also differs in the two Provinces, extending from the 1st of April to the 20th of October in the Upper, and from the 1st of February to the 20th of October in the Lower. The height of the season is from the latter end of May to the end of June; during this period too the trout are in their finest condition.

Their usual run is from two or three ounces to two pounds, size depending always less on age than on the abundance and nature of their food. In respect to the latter point, the most fattening is undoubtedly flies: a fact which has been satisfactorily proved by an interesting series of experiments made for the purpose of testing their nutritious effect as compared with that of worms, minnows, and other objects.

The minnow is commonly considered the most successful bait in the earlier months of the season, though the fly is the best later. In the beginning of May there is such an extraordinary visitation of insect life on the surface of almost every water, that for the short period during which it lasts no fish will look at an artificial fly. These May flies, if not identical with oursa point which I regret I did not investigate at the time,very much resemble them, and alight in such myriads on the water, that it is often literally kept in continual agitation by the rising fish. 
Whilst the trout is one of the most voracious it is also one of the most cunning and wary of all fish. In the nature and quality of its food it is far less particular than the pike, but at the same time its extreme caution and its wonderful keenness of sight demand the utmost craft and address of the angler: a fact which applies in no less a degree to bait fishing.

Warm and rather dull weather is undoubtedly the most favourable, and the fish appear to take more freely during the forenoon than later in the day. In the very hot weather trout do not rise freely, except in the early hours of the morning, though they will occasionally take again in the evening; but by far the best time is from daylight to about 7 A.M.

The trout in. Canada enjoys all but complete immunity from the deadliest of the visitations incident to fish life, namely, the ruthless net; for except only in that part of the river St. Lawrence which flows through the Lower Province, it is unlawful to fish for them at any time of the year with any kind of net whatever.

With regard to the flies best adapted for trout fishing in Canada, it is impossible with so great a variety of streams-some clear as crystal, others darkly coloured, some still and deep, others again swift and shallow-to name particular flies applicable to all, but as a broad general rule, black and red hackles, and middle-sized 
hooks (1 to 12 Limerick) may be used for both lake and river. The following list by the Superintendent of the Lower Province Fisheries may be considered superior to most, having been selected by so excellent a practical fisher, and tested in the waters of both Provinces.

1. The red-hackle and red-palmer; these are flies that invariably kill in the early seasons.

2. The Dun fly-bittern wing, brown body, and red hackle, tinsel gold.

3. Brown fly, for June-English partridge wing; body brown mohair; red hackle, twist of green peacock's herl.

4. Grey-drake-wing, black body and hackle, with silver tinsel.

5. The Orange-dun-starling's wing; body, squirrel's fur ; red hackle, and gold tinsel.

6. Black-ant - light coloured wing; ostrich black herl; black hackle, twist of peacock's green herl.

7. English partridge wing; fur of hare's ear for body; dirty red hackle, silver tinsel; antennæ, partridge wing fibres.

8. Blue-bottle-pale wings; body, of peacock's green and copper herl mixed; hackle, black.

9. Guinea-fowl wing; blue body, black hackle, and silver tinsel.

10. Green-drake - mallard's mottled wing, stained 
olive; head and tail, coppery peacock's herl; body, yellow floss silk, ribbed with brown; antennæ, rabbit's whiskers.

11. Grey-drake-mallard's mottled feathers, to stand upright; body, white floss silk, ribbed with brown; antennæ, rabbit's whiskers.

12. Partridge-wing; body, of peacock's green and coppery herl mixed; red hackle; antennæ, red hackle fibres.

13. Grouse-wing; body, claret, pig's down, red hackle, gold tinsel (a deadly killer).

All these, as well as the before-mentioned salmon flies, may be obtained of Mr. Farlow, 191, Strand.

As to the best trouting waters, it is only possible, where a fish is so widely distributed, to mention a few of the chief, leaving of necessity a vast number of excellent streams unnoticed. All, be it remembered, are deserted in the winter, at which season the trout resort to the deep water of the lakes.

In the Western Province, the Sault Ste. Marie, on the outlet of Lake Superior, affords a plentiful supply of trout, and excellent sport, while the surrounding scenery, with its foaming rapids and beautifully wooded islands, is most romantic. The angler will find the village on the American side a convenient resting place, and may easily kill here two or three dozen fair sized fish in the course 
of a morning. In fact, all the rivers of Lake Superior swarm with trout.

The Manitoulin Isles, on the broad expanse of Lake Huron, themselves contain many small lakelets, most of which are stocked with trout, and in the principal lake, as well as in the rivers on the largest island of the group, they are very abundant. The Manitoulins, which are exclusively inhabited by Indians, may be reached from Penetanguishene, and are well worth visiting.

The Upper St. Lawrence also affords fair trouting. No way inferior is the Upper Ottawa already described, and indeed the whole course of that beautiful river; also the Gatineau and its tributaries.

In Lake St. Philip a party of three of the Rifle Brigade, from Quebec, last year took upwards of 700 trout with the fly in fourteen hours' fishing. The greatest abundance of fine trout is met with in the upper part of the Montmorenci, a river renowned both for its splendid cataract and picturesque scenery.

With the exception of the drive to Jacques Cartier, I know few more agreeable than that from Quebec to the Falls of Montmorenci in one of those antique and most comfortable vehicles called a "calashe."

After leaving the steep and narrow streets, with their lofty rows of quaint old houses, the road is shaded by fine trees, and affords at many points beautiful views of the 
noble river covered with shipping; the purple mountains, and the distant sea. The constant "Hi doncs" and sacrés of the driver; the priests and nuns moving in all directions; and the ever-recurring Virgin Marys and shrines by the wayside, are suggestive of Southern Europe; while the wooden houses and bright tin roofs, the rough snake-fences, and towering hickories are forcible reminders of America.

The Montmorenci Fall is one unbroken sheet of water, higher than that of Niagara, and is lost in a cloud of spray, which far below the feet of the spectator is spanned by a rainbow down among the sparkling trees that spring from the clefts of the rocks. The dark eddying pool into which one looks, is covered with what appear from the height to be sticks or straws spinning on the boiling surface, but are in reality large pine trees which have been carried over the cataract.

There is abundance of trout fishing in every direction within a few miles of Quebec, as the following list taken from Mr. Nettle's* description of the lakes and rivers affording this sport will show: "Lake St. Joseph, Lake St. Charles, Lake Laurent, Lake Joan, Lake McKenzie, Lake Beaufort, Lac Sagamite, and other less important lakes; rivers St. Charles, Joan, St. Pierre, and many inferior streams.

* Fisheries of the St. Lawrence. 
Lake St. Joseph, distant about twenty miles from Quebec, is a most magnificent sheet of water, and has excellent fishing for both trout and basse; the trout fishing in June and July. The other lakes abound in trout, but those that are nearer to Quebec have been much injured by fishing during spawning time.

Lake St. Charles has long been famous for affording splendid sport. This lake is in shape like an hour-glass, narrowing at the centre; immense fish are occasionally taken in it, though formerly they were much more abundant. The Narrows is a favourite spot for fishing. At the head of the lake there is a different species of trout caught-called the Silver-trout-owing their peculiarity solely, I believe, to the existence of fine sand banks in that locality. Some persons prefer fishing in the lower lake. The large fish are generally taken at day-break with bait lines.

Lake Beaufort is my favourite lake, and here the finest fish in Canada are taken. In shape, colour, and flavour no other trout can equal them. It is indeed a fairy spot, embosomed on all sides by woods, with here and there a farm. I can conceive no enjoyment equal to a day or two spent in the month of July at this lovely place. I consider one Lake Beaufort trout to be worth half-a-dozen from any other lake, and any evening in the months of June, July, or August, you may chance to 
get some very good sport. The green drake is the fly for this lake in July, though I have killed some fine fish with the black fly, the body tipped with red or yellow; and with the yellow wing, with brown body and red hackle."

The river Etchemin, on the southern shore of the Gulf, and the lake of the same name, from which it issues, afford excellent trout fishing. Also on the northern shore the inlets of the Saguenay, and the small river, the name of which I have forgotten, which debouches close to the mouth of the Moisie, abound in very large trout: instances which might be multiplied to almost any extent. Col. Drummond Hay, with one friend, killed a little above the fishing station of Coudre, on the Moisie, in nineteen days, 200 dozen of trout, weighing $3,800 \mathrm{lbs}$; one of the days producing no less than 226 fish, the weight of which amounted to $390 \frac{1}{2} \mathrm{lbs}$. The greater part of these fish were $3 \mathrm{lbs}$. and $3 \frac{1}{2} \mathrm{lbs}$. weight, and a few weighed $4 \frac{1}{2}$ lbs. A letter which I have just received from Quebec reports an excursion to Snow Lake, fifty miles from that city, on which occasion two rods alone killed in seven days about 90 fish, lake trout and speckled trout, twenty of which weighed from 7 to $12 \mathrm{lbs}$. each, and one $14 \mathrm{lbs}$, the majority being from 2 to $4 \mathrm{lbs}$. They were taken with the minnow, through holes in the ice; the larger ones were almost as black as ink on the back, being bronzed and speckled on the sides, and very fat. 
The Common Lake Trout (Salmo confinis), which inhabits the deepest waters of the Great Lakes, is the least to be commended of all the Salmonidx, and is indeed an unworthy member of the family to which it belongs, never taking the fly, and even when hooked with the minnow, or a bait of fat pork, ignominiously allowing itself to be hauled passively into the boat. The flesh, too, which is of a dirty yellow tinge, is poor and tasteless. To complete its list of bad qualities, it is a voracious destroyer of the young of the Coregonus albus; pampering its own worthless carcase with the most delicious and valuable fish of the Lakes.

It is dark coloured, mottled over with greyish spots, and is rather broad in proportion to its length ; it commonly averages from eight to nine pounds in weight, though I have seen cuts on the table, at Toronto, which must have come from fish of far larger size. Fish of five pounds' weight up to fifteen may be caught with "the spoon" in Lake Superior almost as fast as they can be pulled out. In winter they are caught weighing as much as sixty pounds, in some of the Lakes, through a hole cut in the ice.

There are several varieties of Lake trout, though very similar to one another in habit and qualities; the Mackinaw-trout (Salmo amethystus) being the chief in point of excellence as it is in size; attaining frequently enormous proportions. 
Though unknown in either Erie or Ontario, it is found in all the great lakes lying north of them, and is most abundant near the outlet of Lake Superior. Excepting in the autumn, when it resorts to shallow water for the purpose of spawning, it inhabits only the deepest parts of these immense reservoirs.

The flesh is red, and very superior to that of the common Lake-trout, though by no means equal to either sea-trout or salmon.

The Mackinaw-trout will not look at the fly, indeed living at such a depth he is not very likely to see it, and "the spoon" is the only certain attraction. This fish is not always proof against a well-played minnow; but as a rule, does not take any bait very readily. The only successful mode of fishing for it is from a boat, which must be rowed very gently through the water.

The Sea-trout (Salmo trutta marina), in all respects precisely similar to that of our own waters, and like it called indiscriminately Salmon-trout, White-trout, or Sea-trout, is found plentifully in most of the bays and salmon streams below Quebec, and often in extraordinary abundance. In the Ste. Marguerite, already spoken of as a tributary of the Saguenay, in the Portneuf, the Netagamu, and the mouth of the Manitouriver, on the northern shore of the St. Lawrence; in the Mount Lewis river on the southern; in the rivers flow- 
ing into Gaspé Bay and the Bay of Chaleurs; in the Tartigo, Blanche, Matanne, Chatte, and in many others, they are abundant, weighing from four to seven pounds. The angler can hardly fail in obtaining magnificent sport in any of them from the commencement of the season, and indeed until the salmon fishing begins he need not wish for better. Mr. Nettle in four hours' fishing has taken from 150 to 200 lbs. weight of Seatrout, averaging from one to five pounds each.

They may be fished for from the 1st of February to the 15th of November, and will take freely most of the bright medium-sized or smaller salmon flies; too freely indeed for salmon-fishers, who often find their sport interfered with by them. A scarlet fly is in high estimation at Quebec, and may be got at any of the tackle shops there, which for the bays and salt water is the best that can be used. The body is of scarlet wool, ribbed with gold tinsel, and the wings of scarlet ibis feather. In the brackish water within the rivers, and as far up as the tide extends, there is nothing better than a yellow or bright brown salmon-fly, though the two following are much used:-1. Body, red mohair, claret hackle; tail of claret hackle, with gold tip; wings, blue-jay wing feathers. 2. Body of green silk, ribbed with gold; dark or pale green hackle; hook No. 4 .

By far the most favourable time is when the tide is 
at the flow; it is then easy to capture a basketful of these handsome and delicious fish, which, averaging three pounds in weight, and not unfrequently running up to seven, afford no inconsiderable sport.

They feed on small fry, minnows, and shrimps, the latter forming in spring a large portion of their daily food, and contributing no doubt in a great measure to the fine flavour of the flesh, which is very firm and pink, and thickly curded. In the month of June, when they are in their best condition, the flesh is not to be distinguished from the very best salmon.

The Salmon-trout is an exceedingly handsome fish, partaking, as its name indicates, of the qualities and appearance of these two different members of the same family. According to Yarrell, the gill cover is intermediate in its form between that of the salmon and the grey trout. The back is a dark bluish tint, and the sides and belly are of a silvery brightness, only to be compared to that of the salmon, but beautifully marked with bright scarlet and pale yellow spots, the fins being of a lighter colour than those of the salmon. In the smaller fish the tail is forked, but in those of three years old and upward it is square.

The White-Fish (Coregonus albus), though a beautiful fish, is unfortunately very deficient in those gamelike qualities so essential in the eyes of the angler, rarely 




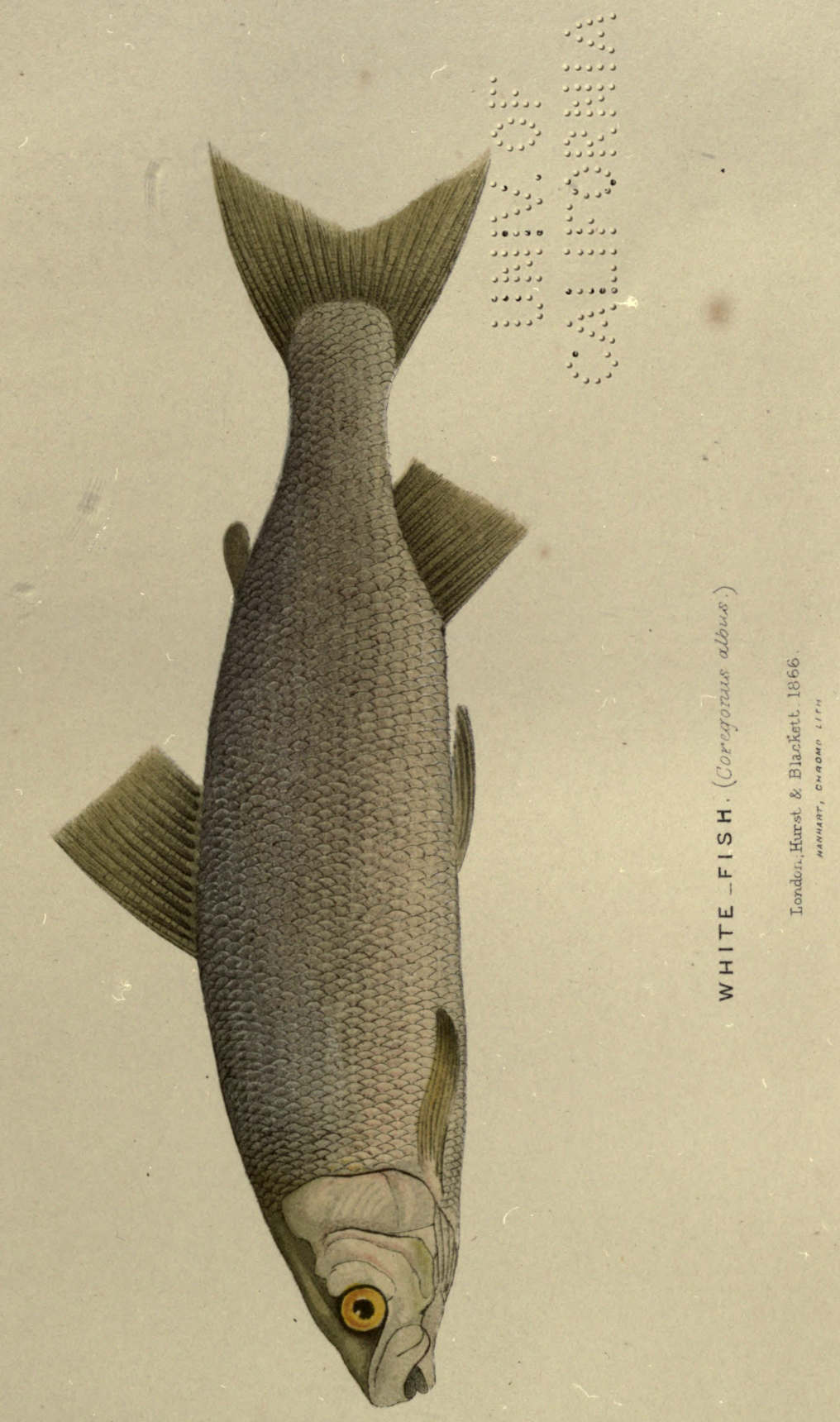



rising to the fly, and caring little for any bait; but it demands more than a mere passing notice, on account of its delicious flavour, its importance as an article of food, and its commercial value, in a trade the importance of which can only be estimated by a perusal of the official returns. That for 1860 , for instance, gives $50,000 l$. sterling as the value of the White-fish alone, which passed through the Customs for exportation from a few fishing stations on Détroit river and Lake Erie, to say nothing of the enormous quantity consumed in the country, to which I shall refer presently.

The White-fish, which is peculiar to North America, is of a pure bright pearly hue, without spot or mark, the upper part of the back only, being of a slightly darker tinge. It is in form and general outline very like a grilse, only that the snout is more obtuse. Its ordinary weight is from two to four pounds; but in some of the more northern lakes, in the colder water of which it seems to thrive better, five and even eight pounds is not an uncommon weight.

It is not only gregarious, but swims in immense shoals, and is strictly speaking a lake fish. It sometimes enters the rivers in autumn, generally in October, for the purpose of spawning, but perhaps more frequently deposits its ova on the gravelly shallows of the lakes, in either case immediately afterwards returning to the deep water. 
It has been erroneously asserted that the White-fish is only found in the Lakes above the Falls, but it hardly requires my testimony to having seen them taken with the seine-net by hundreds in Lake Ontario, and having eaten them fresh from its waters month after month. This Lake in fact ranks among the most productive of these fisheries, as already shown in a former chapter, in which it was stated that no less than 47,000 Whitefish were on one occasion taken at a single haul.

When it is remembered that it thus abounds throughout the whole chain of lakes as far as Lake Winnipeg, penetrating also to the mouths of the rivers emptying themselves into the Arctic Sea, its importance may be duly appreciated. Great quantities are taken at the Rapids of Sault Ste. Marie, until lately a fishery of the Chippeways, who in their frail canoes ran the fall, which is about eighteen feet high, and in the eddies at its foot took the fish in scoop nets; but now, as Mr. Catlin says, "it has been found by money-making men to be too valuable a spot for the exclusive occupancy of the savage, like hundreds of others. The poor Indian is styled an intruder, and his timid bark is seen dodging about in the coves for a scanty subsistence, whilst he scans with envy the insatiable white man filling his barrels and boats, and sending them to market to be converted into money." These scoop-nets are unfortunately still 
in use, and according to the evidence of the Overseer of Fisheries for Lakes Huron and Superior, two men in a canoe, with poles and one scoop-net, can during the season catch two barrels of White-fish per day; the average value of each barrel being about 10 .

The food of the White-fish is stated by a Canadian gentleman, whose authority I do not presume to question, to be entirely vegetable, and to consist mainly of an aquatic moss and of a species of Alga conferva, with which a considerable tract of the bottom of some of the lakes is covered, intermediately between the shallows and deep water. It is believed by others to feed largely on an aquatic worm about an inch and a quarter in length, which is found in immense numbers in places where shoals of White-fish appear; numbers of these worms, which are also found in the stomach of the fish, are brought up adhering to the nets, from which circumstance it would appear as if they swam in mid-water, and in shoals. But from personal examination of the contents of the stomachs of different specimens, and from inquiry made of Ontario fishermen, I incline to believe that its chief subsistence is on molluscæ of various kinds.

As an article of food the White-fish is invaluable. Up country it affords the chief sustenance of hosts of Indians, squatters, fur-traders, and voyageurs, who without this inexhaustible resource would be unable to remain 
in districts where they now live in comfort and plenty. Owing also to its peculiarly delicate, gelatinous, and nutritious qualities, its constant use is not productive of the distaste or dislike which under similar circumstances would no doubt be produced by almost any other continuous diet. Settlers and travellers always before accustomed to a variety of food, have lived on this solely, for twelve months together without tiring of it, and have declared themselves able to stand more fatigue than when living on flesh.

Were it possible to introduce this fish into some of our larger Scottish Lakes, and find suitable subsistence for it, it would indeed be an acquisition to our waters.

A fish of another family, which is exceedingly abundant in the Upper Lakes, and is becoming in many other parts of the country, is the so-called "Lakeherring;" otherwise Shiner, Moon-eye, or Shad-waiter. Yet beyond the fact of its great abundance, its readiness to take any bait, at almost any season or hour, and its very close resemblance in general appearance to the common herring, less is perhaps really known about it than of many other less common kinds.

It would be difficult to persuade most of those who know the fish by sight that it is not a herring; and the few who have troubled themselves at all with any inquiry 
as to its family and genus will probably tell you that it is a Hyodon, quoting Cuvier as their authority.

It is true that the Hyodons have the form of the herring; and that the above naturalist describes under the name of Hyodon claudalus the Lake-herring, Shiner, or Moon-eye. It is, however, not the least of the disadvantages and inconveniences arising from the use of such local names, which are generally bestowed in the first instance by fishermen, farmers, and uneducated persons, that they are applied to more than one object, as in this instance, where the fish named by some local authority to Cuvier as the Lake-herring, \&c., is of a totally different family to the Lake-herring of which we are treating, and which is generally known as such.

The absence of teeth (exceedingly abundant in the Hyodontide), and the presence of the adjpose fin in this fish, place it among the Coregoni, and I believe it to be the C. Clupeiformis described by Cuvier under the local name of "Herring Salmon." He says:* "Cette espèce, très commune en Amérique, a reçu, comme la plupart des poissons qui sont observés successivement par plusieurs naturalistes, plusieurs noms. Les riverains du lac l'appellent 'Herring Salmon;' on voit par conséquent, que les pêcheurs des différentes contrées du globe ont

* Cuv. et Val. Poiss., tom. xxi. Paris. 
tous été frappés de la ressemblance qui existe entre ce poisson et le hareng, non seulement dans leurs formes, mais dans les habitudes de se réunir en bandes considérables."

This latter propensity is frequently the cause of embarrassment and annoyance to the angler, from the greediness with which they seize the bait intended for fish better worth taking.

When fishing for Basse in Lake Ontario, either with the fly or minnow, but especially with the latter, I have been constantly engaged in taking "Lake-herrings" off my hook, and replacing the bait, and when unlucky enough to fall in with a shoal of these fish, it was difficult to get a chance of hooking anything else.

A Lake-herring just caught, cut into portions and used as a bait, was instantly darted at by the shoal of which it had a moment before formed a part. It is in fact one of the best baits that can be used. These fish, though good enough when freshly caught, are not much esteemed, and are not preserved to any extent, the few that are annually dried being chiefly for local consumption.

With the exception of the above-mentioned two characteristics, the appearance and size of this fish are, as already stated, so similar to that of the common herring that it is unnecessary further to describe it.

Though a few years ago confined to the Great Lakes 
and Upper St. Lawrence, the "Lake-herring," like several other fish, has latterly become more widely distributed by means of the canals, and is now found in parts of the country in which it was previously unknown.

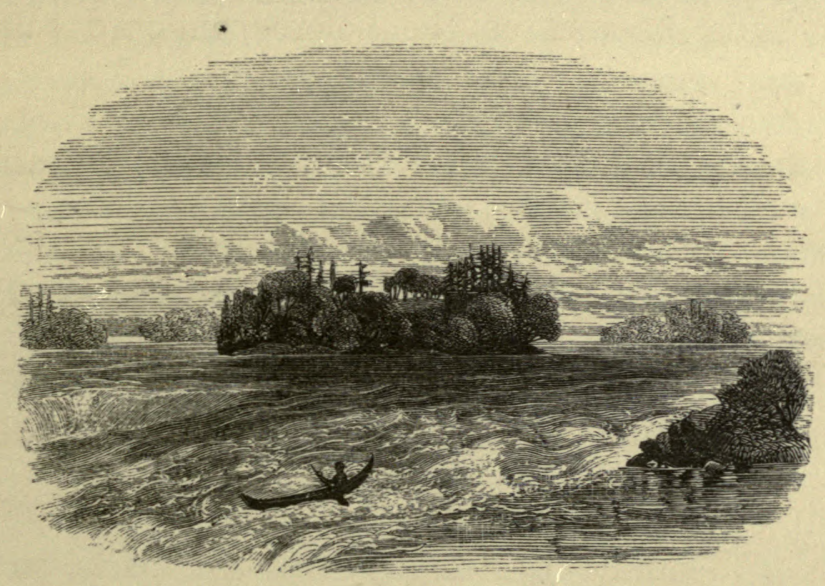

THE CEDAR RAPIDS. 



\section{CHAPTER XI,}

\section{aftalacopteri-continued.}

THE CANADIAN SHAD-COMPARED WITH THAT OF EUROPE-EXCELLENCE OF ITS FLESH - CONFINED TO LOWER ST. LAWRENCE-ITS SIZE AND APPEARANCE-THE PIKE-SPECIFICALLY IDENTICAL WITH OURSNATIVE OF NORTH AMERICA-WIDELY DISTRIBUTED-METHODS OF TROLLING-HABITS OF PIKE-THEIR PRESENCE IN ISOLATED WATERS -THE MASQ'ALLONGÉ-DERIVATION OF NAME-RESEMBLANCE TO THE PIKE-ITS ENORMOUS SIZE-HABITS-CAPTURE OF-WATERS INHABITED BY-THE CARP-THE CHUB-THE AMERICAN BREAM-THE DACE OR "SHINER"-THE ROACH-THE SUCKER-THE CAT-FISHITS UGLY APPEARANCE. 



\section{CHAPTER XI. \\ gbonminales-continued.}

THE Canadian Shad (Alosa prestabilis) differs mate1 rially from our fish of the same name, and is much larger. In shape and appearance it resembles both the bream and the herring, being of a somewhat oval form and having large silvery scales. Its average weight is from 2 to $4 \mathrm{lbs}$., and though rather bony it is an excellent and delicately flavoured fish, especially when freshly taken. It is cured in large quantities, and the roe is preserved as a bait for other fish, for which purpose it is in high repute.

The Shad is said to take readily almost any bright fly in the months of April and May, but I think this is an error; they are seldom taken with the rod, and can barely be classed among the game fish of the country, for they are chiefly taken in "brush fisheries."

They leave the salt water and ascend the rivers in spring for the purpose of spawning, and at that time are abundant in the lower St. Lawrence, though not found higher up than the mouth of the Ottawa, and even at that point only in small numbers. 
The common herring, ${ }^{*}$ generally called in Canada the Gulf Herring and Labrador Herring, constitutes one of the most important articles of commerce in the country, and therefore demands a passing notice, though not included in the category of either game or freshwater fish. They generally appear on the coast in October, at which time they leave the depths of the northern seas, in large shoals, for the purpose of depositing their spawn; the increased temperature obtained in the shallower waters being a necessary condition to its coming to maturity. These shoals are often miles in extent, and from two to three feet in depth. Having spawned, they retire to deep water again, and the fishing ends for the season.

For the encouragement and development of the herring and other fisheries, Canadian owners of Canadian built vessels employed therein, are, under certain other conditions, entitled to a bounty of so many dollars a month per ton.

The trade in these fish is immense, but might be even more considerable than it is, were greater care exercised in their curing than is sometimes the case.

The common Pike of Canada (Esox Lucius) is pro- 
nounced by Cuvier to be specifically the same as the European one.

The Pike is one of the native fish of North America, which country has been not inaptly termed the headquarters of the family, for while we in Europe have only one species, it has several, and among them one that may well be called the chief of the clan, and of which I shall speak presently.

The common Pike abounds in all the waters of Canada from east to west, and many have supposed from its identity with ours, that the latter, which is an importation into Britain from some other country, may have been brought over from Canada; but Yarrell tells us that pike are mentioned in an Act of the sixth year of the reign of Richard the Second, viz., in 1382, or long before North America was even discovered. It is, I think, more likely that our fish originally came from Germany.

Though spread over a very large area of the globe, being it is said geographically distributed with the sprucefir, the pike undoubtedly arrives at its greatest perfection in the cooler regions. Its average weight in Canada is from five pounds to ten pounds in ponds and rivers, but in the Great Lakes it often attains a much more considerable size, possessing also when taken from these clear and beautiful waters the advantage of being per- 
fectly free from the earthy taste which is in general so great a drawback to its flavour.

August, September, and October are the best months for trolling, as the pike are then in first-rate condition, and take most freely; for though they may be captured with the natural bait throughout the summer, either morning or evening, and if the sky is at all cloudy at almost any hour of the day, they are generally lazy and indifferent to food in hot weather, and not easily moved. In winter they will take readily any ordinary bait dropped through a hole cut in the ice, darting on it at once, from beneath the overhanging stones and stumps to which they retire at that season.

On the lakes it is best to fish from a boat, which should be stationed over the weed-grown bottom of some quiet bend or inlet where there is no current, and where the surface of the water is comparatively smooth. The boat should not be too close to the shore, and the greater the length of line the better consistently with convenience in casting the bait, which it is hardly necessary to remark cannot be too lightly dropped into the water. The best sized hook is No. 5 salmon hook. In river trolling, where slow running streams are bordered by reeds, or covered with patches of surface weed, it is better to fish from the bank.

During the Fall pike appear generally to prefer 
deeper water than in summer, at which season they frequent the middle depths or bask in the sun under floating water-plants. Though the pike is not gregarious, yet where one is taken others will always be found in the same neighbourhood, and the troller should by no means abandon his ground under the impression, which is a very common one, that it is a solitary fish : an error first propagated by Isaak Walton, who says, "the Pike is observed to be a solitary, melancholy, and a bold fish : melancholy because he always swims or rests himself alone, and never swims in shoals or with company, as roach, and dace, and most other fish do; and bold because he fears not a shadow, or to see or to be seen of anybody, as the trout, and chub, and all other fish do."

Yarrell however, mentions the fact of an annual migration of this fish taking place in spring in the Cam, into which river he says "they come in great shoals, doubtless, from the fens in the neighbourhood of "Ely, where they are bred." I have myself often seen pike in company; and it almost invariably occurs that when one is taken from a hole he is succeeded at once by another.

The most successful lure, when it can be procured, is the "pickerel frog," a small and singularly marked creature. A minnow, or a small "lake-herring," bream, or any other similar fish will however always answer. Artificial bait or flies seldom attract, and the angler 
need not waste his time or patience in experimenting with them.

A large pike will frequently run the whole line off the reel, darting away with a strength and velocity which call into play all the skill of the angler, who should be provided with a good rod with a stiff top, and plenty of strong silk line, the nature of his other tackle being matter of choice and preference, though gorge-tackle is undoubtedly the most simple and efficacious.

Pike are also taken in other ways, as by spearing, which in winter is effected through a hole cut in the ice, to which the fish are attracted by bait; and in summer by torchlight from a canoe or a scow, and by other means even more uninteresting to the sportsman.

Though the finest pike are found in the Great Lakes and in the St. Lawrence, some one or other of the various species belonging to North America, exist in almost every stream and pool throughout the country. All these are indiscriminately called "Pickerel," and are popularly supposed to be one and the same fish at different stages of growth. The distinctions between them however are not sufficiently important to render any separate description necessary. I have thought it more desirable to notice the abundance of the Common Pike (E. Lucius), as its existence in North Americ l has been denied by more than one writer. 
The small lakes on the Manitoulin Islands contain many large pike; and in the lagoon on the shore of Lake Ontario, before alluded to as the resort of wild ducks, I have frequently seen large ones sunning themselves; but in this place they are not easily tempted by any bait, probably on account of food being so plentiful, for the water literally swarmed with frogs and young fish.

It is not easy to account for the presence of pike in many of these isolated pools and small lakes, where, as in the case of this lagoon, there is no stream whatever flowing into or out of it. Yet it is conceivable that in some instances by ordinary causes, such as floods or the alteration of land level, fish may have found their way into such places, without our supposing with Gessner that they are bred from aquatic plants by help of the sun's heat!

One of the most remarkable inhabitants of the Great Lakes belongs to this family, namely, the celebrated Masq'allongé (Esox estor of Cuvier) generally but erroneously called Maskinongé, Mascalongé, Muskalinge, Maskalunge, and other barbarous corruptions of two simple French words, signifying "long face."

It bears a very strong resemblance to the foregoing, though on examination several specific differences are to be observed in addition to the very obvious ones of its far greater size, and the deepness of the body in proportion 
to its length. Its habits are nearly identical with those of the pike, though it is very seldom if ever to be seen basking, and appears generally to inhabit only the deepest waters.

The back is of a very dark and somewhat greenish hue, and the under parts of a beautiful silver-grey, the two colours meeting and blending together on the sides, which are marked with a few irregular patches. The scales are very small and extend over, and cover the cheeks.

Masq'allongé of twenty pounds weight are common, and instances are recorded in which they have been captured with the rod as heavy as sixty and even seventy pounds. The voracity of these monsters appears to be proportionately enormous, for it is no uncommon occurrence to find fish of several pounds weight in the stomach.

The sport afforded by the capture of such leviathans may be easily imagined, and as they are neither rare to find nor difficult to tempt if properly dealt with, masq'allongé trolling may lay claim to considerable attractions.

According to the provisions of the Canadian Fishery Act it is unlawful to take them between the 15th of March and the 15th of May, but they may be fished for at any other time of the year. 



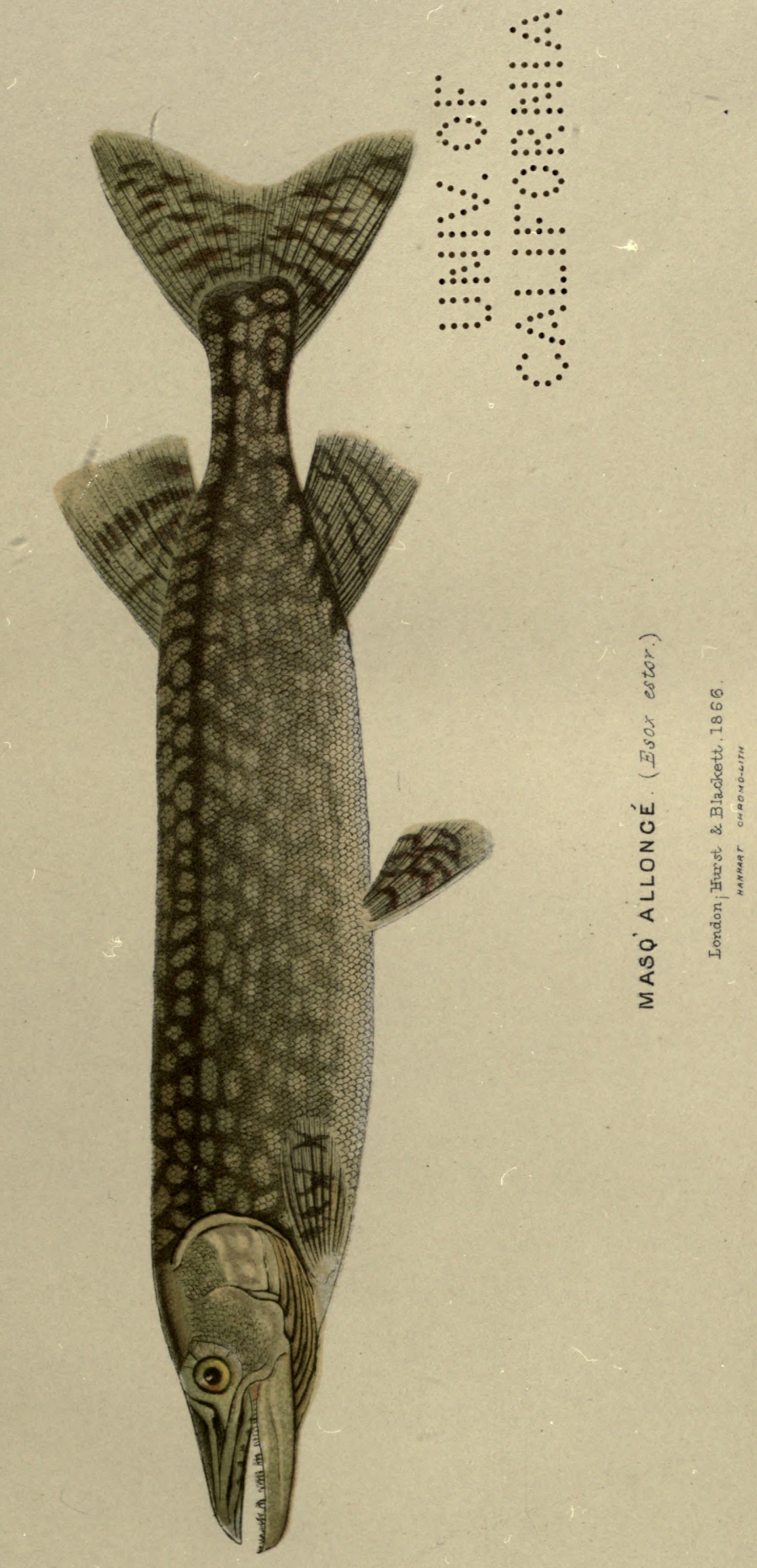



The natural bait is not often found to answer, perhaps from the insignificance of the size ordinarily employed, and the fly is never successful; in fact, as may be supposed, it would be quite useless to try it with a fish habitually keeping at so great a depth. The usual and most deadly lure is the "spoon," which, though resembling nothing in nature, and devoid of taste or smell, appears, for what reason it is difficult to imagine, to be perfectly irresistible to this as well as to many other fish. This attractive instrument, which is simply a piece of brass or other bright metal shaped like the bowl of a spoon, with a large hook fixed on it, is made to spin by means of the swivel, in the same manner as the minnow in ordinary trolling. The angler, provided with this simple and enduring bait, with a stout rod and very strong tackle, is pulled gently and slowly along in a scow over the weedy depths of the lake, having out sufficient length of line to keep his hook as far as possible away from the oars or paddle, which are otherwise apt to scare away the fish.

In this way Masq'allongé of 30 or 40 lbs. may often be taken, not of course so plentifully as trout or salmon, yet the amount of time and excitement involved in a single capture is almost equal to an ordinary day's fishing. I do not of course allude in any way to the practice of affixing the bait, as is sometimes done, to a sea-line or 
stout cord wound round the wrist, and so hauling in the fish by main strength : an uninteresting and unsportsmanlike business of two or three minutes.

Masq'allongé inhabit chiefly the "Great Lakes," properly so called; but abound in the Upper St. Lawrence, especially in the quiet and less frequented channels of the Thousand Isles, in Rice Lake and Clear Lake north-west of Kingston, in the Ottawa, Gatineau, and in many other waters.

The common Carp (Cyprinus carpis) is found in most of the lakes and rivers throughout Canada. The Chub (Cyprinus cephalus) is common, as is also the Bream (Abramis versicolor), which I have killed on the Niagara River and creeks, with the worm, a bait they take readily. The Dace (Leuciscus argentatus), which, in common with one or two other fish, as already mentioned, goes by the name of the "Shiner," and the Roach (Leuciscus rutilus), are also abundant, all the above differing very slightly, if at all, from those of Britain.

Unimportant, and generally despised as these minor fish are in Canada, where there are so many far superior ones, some of my old comrades who may read these pages will recal the amusement, rather than sport, that they afforded us on various perch-fishing expeditions. How, when our horses were unsaddled and picketed, and a fire lighted at the water's edge, we commenced to pull out 
first one kind and then another as fast as the most unreasonable angler could wish; and how, as they were caught they were split open, fried on the wood-ashes, and eaten with a relish which their own merits never deserved.

A very common and inferior fish, belonging also to the Cyprinida is the Sucker (Catostomus communis), the body of which is from eight to twelve inches in length, rounded and tapering, the colour varying at different seasons. The head is smooth, and the mouth protracted in order to enable it to grovel in the sand, where it is very destructive to the ova of other fish.

A frequent source of annoyance to the angler for pike and basse is the Cat-fish (Silurus pimelodus), which is continually taking his bait. This is an ugly looking ill-shaped fish, covered with a greenish yellow skin devoid of scales; about the mouth are some six or eight fleshy horns or filaments, from one to two inches or more in length, according to the size of the fish. These probably serve the purpose of feelers, for I have more than once observed the fish in shallow water swimming round a bait at the full extent of these tentacles, and suspiciously touching it with them before venturing nearer. This reconnoissance however, if such it be, does not appear to avail them much, for there is no fish more easily taken. They are of all sizes, from the length of a finger to 
that of an arm; very large ones are sometimes brought up in the lakes by the fishermen's nets, for they keep mostly at the bottom, being what is termed a "ground fish." They are said only to leave their depths when boisterous weather is impending, a curious instinct causing them to approach the surface some hours in anticipation of the coming storm. It is not true, as has been stated, that when taken they make a noise resembling the purring of a cat; this peculiarity belongs to a totally different.fish.

The flesh is, very fat and said to be excellent; but though I have caught them in scores, involuntarily, I was never tempted to try the taste of one.

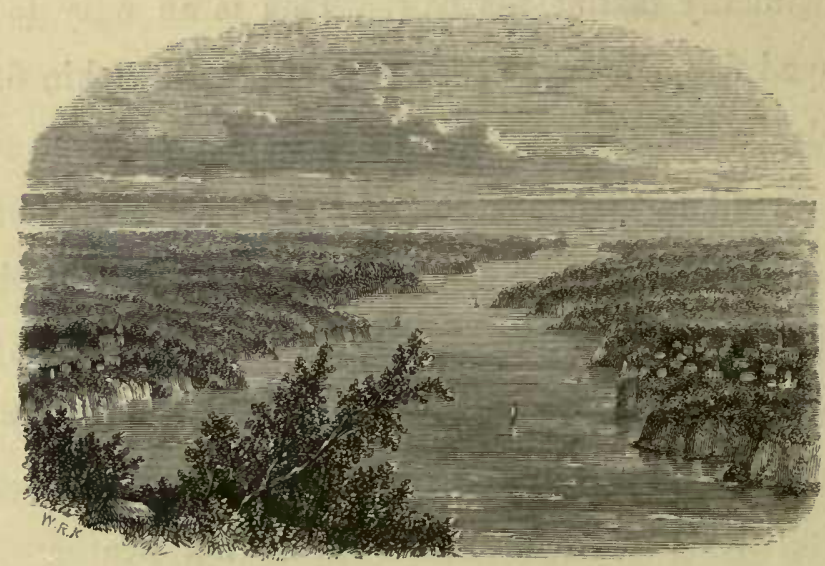

NIAGARA RIVER, AND LAKE ONTARIO. 


\section{CHAPTER XII.}

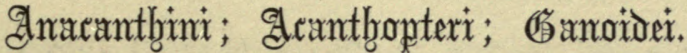

THE "TOM-COD"-ITS ANNUAL ARRIVAL IN THE GULF-FISHING THROUGH THE ICE-FREEZING AND RESUSCITATION-THE YELLOW PERCHVARIETIES - THE BLACK-BASSE - FLY-FISHING FOR - BLACK-BASSE PECULIAR TO NORTH AMERICA-ITS COLOUR, FORM, AND WEIGHT, -WHERE FOUND-GREGARIOUS CHARACTER-EASILY TRANSPORTED, -WORTHY OF ACCLIMATIZATION-THE ROCK-BASSE-ITS SIZE AND COLOUR-ITS QUALITIES AND ABUNDANCE-THE WHITE-BASSE-COMMON IN UPPER LAKES-A BOLD BITER-THE STRIPED-BASSE-COMMON TO SALT AND FRESH WATER-ITS GREAT SIZE-MARKINGS AND COLOURTHE OSWEGO BASSE-ERRORS CONCERNING IT-THE COMMON LAKE SHEEPSHEAD-THE BLACK SHEEPSHEAD-CONFINED TO THE UPPER LAKES - ITS RESEMBLANCE TO PERCH - EXCELLINT FISH - THE STURGEON - ITS IMMENSE GROWTH - ABUNDANCE IN ONTARIOABSENCE IN NORTHERN RIVERS-STURGEON MEAT. 



\section{CHAPTER XII.}

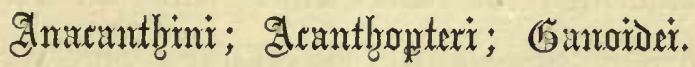

7 HE Tom-Cod, sometimes also called the Frost-fish 1 (Gadus tom-codus), the Petite Morue Fraîche, Tacaud, and Gode Mollet of the French-Canadians, is peculiar I believe to North America. It is best known in the Lower St. Lawrence, along the shores of the Gulf, in the Bay of Chaleurs, and on the coast of Gaspé, especially at the mouths of the rivers and barachois.

These fish make their annual appearance in the above waters, in autumn and early winter, at which time they leave the sea for the purpose of spawning, and are taken for some distance up the St. Lawrence in great abundance during December and January. In the lower part of the Eastern Province they are taken with lines and nets, and also in boxes made for the purpose. This last named apparatus is used with much success at Champlain and the neighbouring parishes on the north shore, where the fish are not unfrequently used for feeding cattle.

At Montreal and Quebec they afford a very favourite 
winter pastime to large numbers of all classes, who fish for them with a bait and line through holes cut in the ice. Huts or cabans are built for this purpose on the frozen surface of the river, and to these the good citizens resort at night in friendly parties. Many jovial gatherings of this kind will be recalled by the sojourner, especially the military one, at Quebec, where they are held on the St. Charles river, at its junction with the St. Lawrence and just opposite the city.

Sometimes as many as eighteen or twenty dozen fish are killed in one night. A great proportion are cooked and eaten in the cabans there and then, but those intended to be preserved are thrown outside on the ice to freeze, the excessive tenderness of their flesh rendering it impossible to preserve them in any other way. Thus treated they soon become stiff and hard, and so brittle that they may be snapped in two like glass; but it is a curious fact that the fish thus frozen will, on being taken home and immersed in cold water, recover their vital powers and shortly begin to swim about. This singular suspension of animation is entirely dependent on the freezing being allowed to take place immediately on their withdrawal from the water, for naturally they are by no means tenacious of life.

In the frozen state they may be preserved in an eat- 
able condition for a long time, provided the air be carefully excluded from the vessels in which they are kept.

The Tommy-Cod varies in length from six to ten inches, and in weight from a quarter of a pound to a pound. It is a very pretty little fish, and in appearance so much resembles the common cod, that were it not for the fact of its coming up the river to spawn, it would be difficult to persuade the ordinary observer of the fact of its being a full-grown and distinct species.

The Common Perch of our own country is not found in Canada, but the Yellow Perch (Perca flavescens), which is a variety, is a very handsomely marked fish, the under parts being of a golden yellow, the back a dull green, the dorsal fins dark, the pectoral and anal ones red. It is common in almost every lake and river, and takes both minnow and worm very boldly.

Among other varieties is $P$. acuta, which is found in Lake Ontario, and in other waters, but among so many larger and better fish none of them attract much notice.

Except the salmon, there is hardly any other fish that affords more thorough sport, or deserves to rank higher in every way, than that prince of fresh-water fish, the Black-Basse (Huro nigricans).

Though not particularly difficult to tempt, it is yet sufficiently so, and must be approached only with a fine 
line and a skilful hand. Well-made tackle is however, equally indispensable, for when hooked it will run a lot of line off the reel at once, shooting away with extraordinary fury and impetuosity, leaping madly out of the water, darting in towards the angler, and not unfrequently under the boat, and with such strength and activity as demand all the care and address of its captor. Last, though not least, game as it is in its own sphere, its firm flesh and extreme delicacy and richness of flavour, rank it as high in the estimation of the epicure as in that of the angler.

Exclusively North American, the Black-Basse is a perch-like fish, averaging from three to five pounds in weight, and with a depth proportionate to its length as one to three; it has, I believe, been taken weighing as much as eight pounds.

In colour it varies very considerably at different stages of its growth, the young fish being a dull light green, changing year by year in hue till full grown, when the head, back, and shoulders are almost black, shaded off on the sides into a dull bronze, which again merges imperceptibly into a bluish-white belly. The young, besides their difference in colour, have a smaller proportionate depth of body.

They are fished for from the 15th of May till the 15th of March. During their spawning time they will 



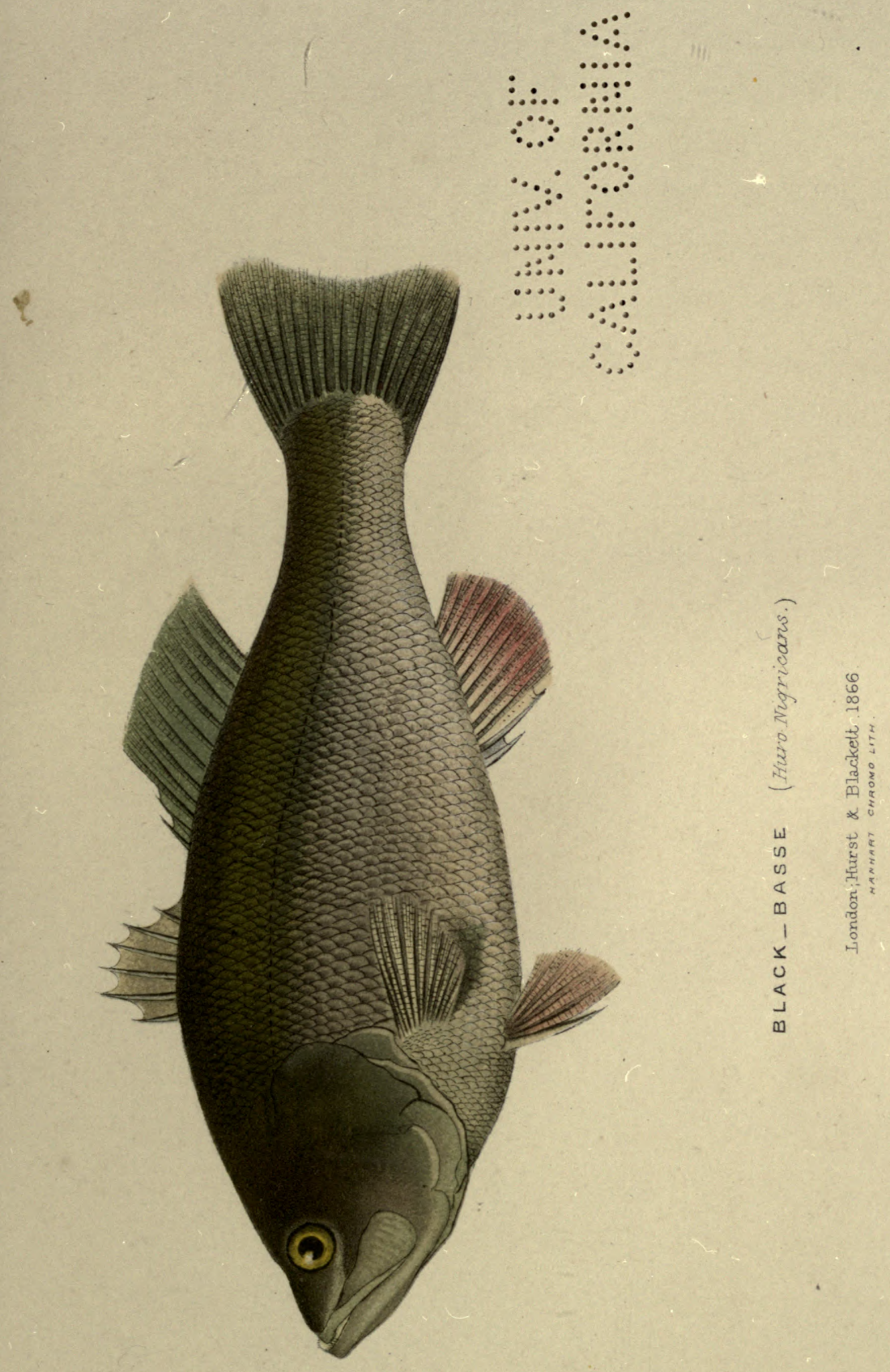



not touch the most tempting bait, nor are they fit for food even were it otherwise, but they may be taken with the rod from the commencement of the proper season till the cold weather begins, when they can only be obtained by means of the net.

During June and July they will not only take the minnow or the "shiner," but rise freely to the fly, and so long as they are in the humour to take this, no true fisherman would think of trying anything else. The best and most successful flies, according to my own experience, are the following:-

Body of scarlet wool, ribbed with silver; with two pairs of wings, one of silver pheasant, the other pair of scarlet ibis ; or,

Scarlet wool body, with wings composed of two white feathers from the goose, and under wings of the same dyed scarlet. Either of these flies may be varied by the substitution of very light mottled turkey feather wings.

With these two I have enjoyed many splendid days' sport in the Niagara, anchored in a scow on the bar of the river: a soft warm air gently rippling the surface of the water; the blue Ontario stretching to the horizon on the one hand; and on the other a lovely reach of seven miles up stream, the lofty wooded banks terminating in the cedar-sprinkled heights of Queenstown, and the dark 
gorge in which the river is lost. In a single afternoon I have taken as many as eight or ten magnificent fish, weighing from four to six pounds each, and affording even more sport than salmon of similar weight would have done.

After three years' experience in Basse fishing at Niagara, I would recommend any one angling there, to take his boat across to the American side of the river in preference to remaining on the Canadian shore, and to anchor under the fort, not too far from the bank, as these fish always take more readily in-shore than in midstream.

In a place such as this, it is best to anchor, but ordinarily the boat should be pulled gently along, the angler having out a line of considerable length, as the passage of the boat over the feeding-grounds disturbs the shoals, which will not again return to them until it is some thirty yards away.

The best hours for fishing are from daylight to about eight A.M., and again about three in the afternoon; at the latter hour they begin to feed, and up till dusk may generally be taken in abundance.

In very deep water they are rarely to be moved at all. I have tried every kind of bait and fly out on the Lake, but never succeeded in hooking a single fish at any distance from land. 
In addition to the Niagara bar, the best waters for Basse are the Lake of the Thousand Isles, Lake Erie and the rivers emptying themselves into it (especially the Détroit river), the St. Joseph river, the principal tributaries of Lakes Michigan, Huron, Simcoe, and Ontario; also along the shores of those Lakes themselves in about three fathoms of water, and in the Upper St. Lawrence. Though found abundantly in many other places besides these, they are not known north of the Great Lakes. They love stony bottoms, and reefs of rock, especially where there is an eddy. In large rivers they will generally be found to lie near the sides, and in smaller streams only in the deepest pools.

The Black-Basse appears to be gregarious, at all events it is seldom taken singly, and the angler may be pretty sure of capturing several in the same place. I have heard of two officers at Niagara taking with the rod as many as thirty-six fish in the same place in the course of a few hours.

I have not the smallest doubt that the Black-Basse is quite capable of acclimatization in our own country, and that it would thrive in any suitable waters; and I believe that this might be accomplished with less amount of trouble and expense than would be incurred in the transport of most other foreign fish, or their ova, and certainly with the amplest reward in the event of success.' 
Placed in a bucket or tub of water, covered over with a cloth, large fish bear removal very well, and in instances where they have been transferred to American waters in. which they were not previously known, they have multiplied with extraordinary rapidity.

Besides the Black-Basse, there are the Rock-Basse, the White-Basse, and the Striped-Basse. The former (Centrarchus Eneus), which is found in all the Great Lakes, is smaller than the Black-Basse, attaining not more than half its weight, and is of a greenish bronze colour above, and of a bright coppery hue below, with a few dark spots on the belly. By the latter markings it is readily distinguished from the immature Black-Basse, the appearance of which, as already remarked, varies so much at different periods.

The Rock-Basse bites very freely at the minnow or cray-fish, or at a piece of "lake-herring," which is the bait commonly employed by the Ontario fishermen on their set-lines, and I have taken them with the rod in this manner almost as fast as I could bait my hook. They are caught plentifully by the inhabitants of all the towns and villages around the shores of Ontario, but are very inferior in flavour to the Black-Basse.

The White-Basse (Labrax albidus), which is gregarious, is common in some of the Upper Lakes, and especially so in Lake Erie. It is not only a bold biter, 
taking the minnow even greedily, but gives plenty of . play when hooked, and is tolerably well flavoured. It is smaller than the Black-Basse, weighing from $1 \frac{1}{2}$ lbs. to $3 \frac{1}{2}$ lbs. The under parts and sides are white, slightly streaked, the back being of a dark semi-transparent hue.

The Striped-Basse (Labrax lineatus), which in Canada generally goes by the name of Bar, or Barr, though belonging rather to the sea than the river, frequents alternately salt and fresh water. It is a most excellent fish, and frequently attains a very large size; several weighing thirty pounds and upwards, have, I am informed, been taken in some parts of the St. Lawrence, especially at the Sorel Islands and Crane Island.

The Striped-Basse is so called on account of its having seven or eight dark lines or stripes on its sides, running parallel one with another from head to tail. The general colour of the body is brown above, with a blue tinge, the sides being bright and silvery. It breeds in spring, in the St. Lawrence and several of its tributaries, in the Restigouche and other rivers emptying themselves into the Bay of Chaleurs, and in several more on the southern shore of the Gulf.

"Oswego Basse" appears to be only a local American name for the above fish, although it has been described as having larger scales and a more forked tail, with other imaginary differences, and I have met inany per- 
- sons in Canada who regard it as a distinct species, and expatiate on its great superiority over all other Basse. Having, however, very carefully inquired into the matter, I am satisfied that the two are identical, and am glad to learn by a private letter from the Fisheries Superintendent of Lower Canada that he is likewise of this opinion.

Though Pickerel is a term often applied to young Pike, it is also used to designate a fish properly called the Pike-perch, or Sandre (Lucioperca Canadensis), the Piccarel of the French Canadians, which partakes, as its name indicates, almost equally of the appearance of the pike, and perch, though it belongs to the latter family, and has really nothing to do with the other.

It is a dark green colour on the back, and is marked with a few yellowish irregular spots on the sides, those on the fins being dark. In form it is shorter and deeper than the pike, and the scales are rough; it has also in addition a spiny dorsal fin, like that of the perch. It is taken by trolling, but though exceedingly voracious, and feeding almost entirely on young fish, it does not take the bait freely. It grows rapidly, is met with plentifully in many waters, and is much esteemed.

The Sheepshead (Corvina oscu?a) also belonging to the Perch family, is a dry insipid fish, of a grey colour, with bluish tints on the back. It is common in Lakes Erie 
and Ontario, and is often taken with the rod, though hardly worth putting into the basket.

The Black Sheepshead (Corvina Richardsonii) which is only found in Huron and other Upper Lakes, more resembles the ordinary perch in colour and markings, and unlike the former is a most excellent and highly esteemed fish.

Besides the monsters already described as inhabiting the depths of the Great Lakes, are immense Sturgeon (Acipenser sturio), quantities of which are taken, measuring from eight to ten, and even twelve feet in length, and weighing from 75 to $100 \mathrm{lbs}$.

On the southern beach of Lake Ontario, near the entrance of the Niagara river, I have seen as many as fifteen such fish brought in at one time by the boats.

An account of the Sturgeon in the latest edition of the "Encyclopædia Britannica," states that it "does not inhabit any of the North American rivers which flow into the Arctic Sea, and therefore is not found to the north of the water-sheds between the 53rd and 54th parallels of latitude, where the mean temperature of the year is about $33^{\circ}$ of Fahrenheit's scale. It seldom enters clear cold streams, but at certain seasons ascends muddy rivers in vast numbers, so that many populous native tribes subsist wholly on the Sturgeon fishery during the summer. In most localities 
two forms are readily recognised, by the comparative length and acuteness, or the shortness and bluntness of their snouts; but almost every water-shed has its own species, varying in more or less important points."

The "meat" as it is called, which, when stewed, somewhat resembles veal, is much eaten both by Indians and settlers, and up country affords the chief means of sustenance to large numbers, by whom it is also dried and preserved for winter use. The "sounds" form a considerable article of trade among the tribes of the Northern Lakes.

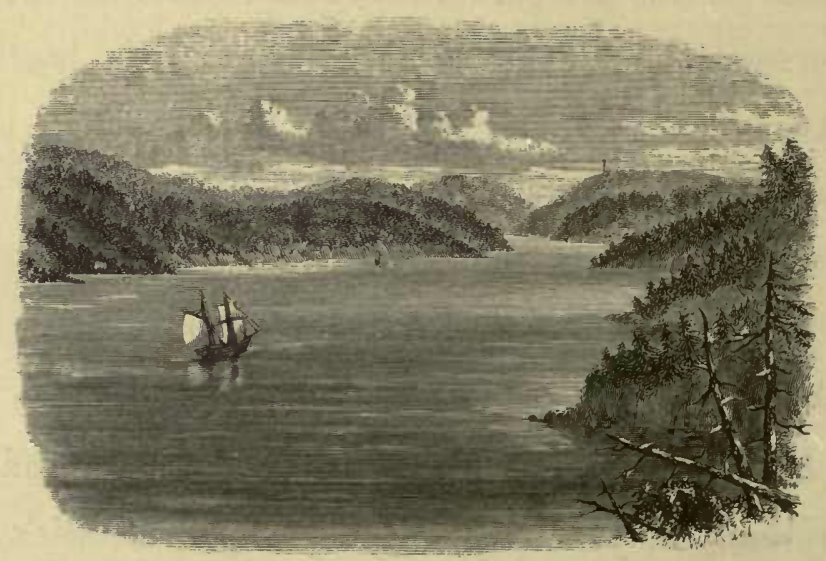

LOWER NIAGAIA RIVER. 


\section{A P PENDIX.}

Extrait des Lois rélatives à la Pêche et à la Chasse, dans le Bas Canada.

ÉPOQUE DURANT LAQUELLE IL EST DÉFENDU DE PRENDRE LE POISSON ET LE GIBIER CI-DEsSOUS MENTIONNÉS, DANS LE BAS CANADA.

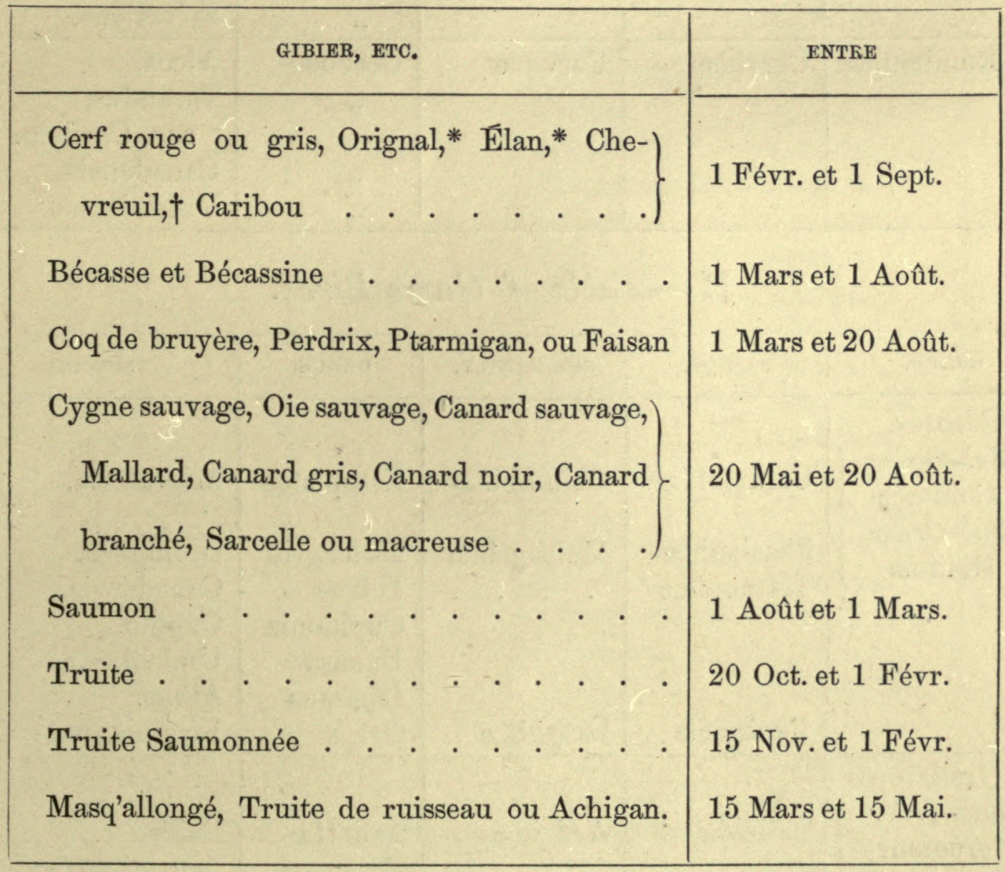

* Both applied to the Moose.

+ The Long-tailed Deer of North-west Territory, C. Leucurus. 


\begin{tabular}{|c|c|c|c|c|}
\hline ORDER. & FAMILY. & SUB-FAMILY. & GENUS. & SPECIES. \\
\hline $\left.\begin{array}{l}\text { 1. Rapacia. } \\
\text { Sub-Order } \\
\text { Carnivora. }\end{array}\right\}$ & $\begin{array}{l}\text { Felidæ } \\
\text { Canidæ } \\
\text { Mustelidæ } \\
\text { Ursidæ }\end{array}$ & $\begin{array}{c}\cdot \\
\text { Lupinæ } \\
\text { Vulpinæ } \\
\text { Lutrinæ } \\
\cdot \quad \cdot\end{array}$ & $\begin{array}{l}\text { Felis } \\
\text { Lynx } \\
\text { Canis } \\
\text { Vulpes } \\
\quad ", \\
\text { Lutra } \\
\text { Ursus } \\
\text { Procyon }\end{array}$ & $\begin{array}{l}\text { Concolor. } \\
\text { Canadensis. } \\
\text { Occidentalis, } \\
\text { var. Griseo albus. } \\
\text { Fulvus, } \\
\text { var. Decussatus. } \\
\text { var. Argentatus. } \\
\text { Canadensis. } \\
\text { Americanus. } \\
\text { Lotor. }\end{array}$ \\
\hline 3. Rodentia & $\begin{array}{l}\text { Sciuridæ } \\
\text { Leporidæ }\end{array}$ & $\begin{array}{c}\text { Castorinæ } \\
. \cdot . \cdot\end{array}$ & $\begin{array}{c}\text { Castor } \\
\text { Lepus } \\
\text { ", }\end{array}$ & $\begin{array}{l}\text { Canadensis. } \\
\text { Americanus. } \\
\text { Campestris. } \\
\text { Sylvaticus. }\end{array}$ \\
\hline 6. Ruminantia & Cervidæ & Cervinæ & $\begin{array}{c}\text { Cervus } \\
\text { " } \\
, " \\
,\end{array}$ & $\begin{array}{l}\text { Alces. } \\
\text { Tarandus, } \\
\text { var. Caribou. } \\
\text { Canadensis. } \\
\text { Virginianus. }\end{array}$ \\
\hline
\end{tabular}

II.-Table of Game Birds.

\begin{tabular}{|c|c|c|c|c|}
\hline ORDER. & FAMILY. & SUB-FAMILY. & GENUS. & SPECIES. \\
\hline $\left.\begin{array}{l}\text { 4. Rasores. } \\
\text { Sub-Order } \\
\text { Columbæ } \\
\text { Sub-Order } \\
\text { Gallinæ }\end{array}\right\}$ & $\begin{array}{l}\text { Phasianidæ } \\
\text { Tetraonidæ } \\
\text { Perdicidæ }\end{array}$ & $\begin{array}{l}\text { Columbinæ } \\
\text { Meleagrinæ } \\
\text { Ortyginæ }\end{array}$ & $\begin{array}{l}\text { Ectopistes } \\
\text { Meleagris } \\
\text { Tetrao } \\
\text { Cupidonia } \\
\text { Bonasa } \\
\text { Lagopus } \\
\text { Ortyx }\end{array}$ & $\begin{array}{l}\text { Migratoria. } \\
\text { Gallopavo. } \\
\text { Canadensis. } \\
\text { Cupido. } \\
\text { Umbellus. } \\
\text { Albus. } \\
\text { Virginianus. }\end{array}$ \\
\hline $\left.\begin{array}{l}\text { 5. Grallatores } \\
\text { Sub-Order } \\
\text { Herodiones }\end{array}\right\}$ & $\begin{array}{l}\text { Ardeidæ } \\
\text { Charadriidæ } \\
\text { Scolopacidæ } \\
\text { Rallidæ }\end{array}$ & $\begin{array}{l}\cdot \\
\text { Scolopacinæ } \\
\text { Totaninæ } \\
\text { Rallinæ }\end{array}$ & $\begin{array}{l}\text { Ardetta } \\
\text { Botaurus } \\
\text { Charadrius } \\
\text { Egialitis } \\
\text { Philohela } \\
\text { Gallinago } \\
\text { Numenius } \\
\quad \text { ", } \\
\text { Rallus }\end{array}$ & $\begin{array}{l}\text { Exilis. } \\
\text { Lentiginosus. } \\
\text { Virginicus. } \\
\text { Semipalmatus. } \\
\text { Minor. } \\
\text { Wilsonii. } \\
\text { Longirostris. } \\
\text { Borealis. } \\
\text { Virginianus. }\end{array}$ \\
\hline
\end{tabular}


III.-Table of Wildfowl.

\begin{tabular}{|c|c|c|c|c|}
\hline ORDER. & FAMILY. & SUB-FAMILY. & GENUS. & SPECIES. \\
\hline $\left.\begin{array}{c}\text { 6. Natatores } \\
\text { Sub-Order } \\
\text { Anseres }\end{array}\right\}$ & Anatidæ & $\begin{array}{l}\text { Cygninæ } \\
\text { Anserinæ } \\
\text { Anatinæ } \\
\text { Fuligulinæ }\end{array}$ & $\begin{array}{l}\text { Cygnus } \\
\text { Anser } \\
\text { "" } \\
\text { Bernicla } \\
\text { An } \\
\text { Anas } \\
\text { Spatula } \\
\text { Chaulelasmus } \\
\text { Dafila } \\
\text { Nettion } \\
\text { Querquedula } \\
\text { Mareca } \\
\text { Aix } \\
\text { Fulix } \\
\text { " } \\
\text { Aythya } \\
\text { ", } \\
\text { Bucephala } \\
\text { Histrionicus } \\
\text { Harelda } \\
\text { Camptolæmus } \\
\text { Melanetta } \\
\text { Pelionetta } \\
\text { Oidemia } \\
\text { " } \\
\text { Eomateria } \\
\text { Mergellus } \\
\text { Mergus } \\
\text { Lophodytes }\end{array}$ & $\begin{array}{l}\text { Americanus. } \\
\text { Buccinator. } \\
\text { Albifrons. } \\
\text { Frontalis. } \\
\text { Hyperboreus. } \\
\text { Brenta. } \\
\text { Canadensis. } \\
\text { Boschus. } \\
\text { Obscura. } \\
\text { Clypeata. } \\
\text { Streperus. } \\
\text { Acuta. } \\
\text { Carolinensis. } \\
\text { Discors. } \\
\text { Americana. } \\
\text { Sponsa. } \\
\text { Affinis. } \\
\text { Collaris. } \\
\text { Marila. } \\
\text { Americana. } \\
\text { Valisneria. } \\
\text { Albeola. } \\
\text { Americana. } \\
\text { Torquatus. } \\
\text { Glacialis. } \\
\text { Labradorius. } \\
\text { Velvetina. } \\
\text { Perspicillata. } \\
\text { Americana. } \\
\text { Bimaculata. } \\
\text { Mollissima. } \\
\text { Rubida. } \\
\text { Albellus. } \\
\text { Americanus. } \\
\text { Serrator. } \\
\text { Cucullatus. }\end{array}$ \\
\hline
\end{tabular}


IV.-Table of Fresh-water Fish.

\begin{tabular}{|c|c|c|c|c|}
\hline ORDER. & FAMILY. & SUB-FAMILY. & GENUS. & SPECIES. \\
\hline $\left.\begin{array}{c}\text { 2. Malacopteri } \\
\text { Sub-Order. } \\
\text { Apodes }\end{array}\right\}$ & Anguillidæ & $\cdot \cdot \cdot \cdot$ & Anguilla & Vulgaris. \\
\hline $\left.\begin{array}{c}\text { Sub-Order. } \\
\text { Abdominales }\end{array}\right\}$ & $\begin{array}{l}\text { Salmonidæ } \\
\text { Clupeidæ } \\
\text { Esocidæ } \\
\text { Cyprinidæ } \\
\text { Siluridæ }\end{array}$ & $\begin{array}{cccc}\cdot & \cdot & \cdot \\
\cdot & \cdot & \cdot \\
\cdot & \cdot & \cdot & \cdot \\
. & . & \cdot\end{array}$ & $\begin{array}{l}\text { Salmo } \\
, " \\
, " \\
\text { Coregonus } \\
\text { Alosa } \\
\text { Esox } \\
\text { Cyprinus } \\
\text { Abramis } \\
\text { Leuciscus } \\
\text { Silurus }\end{array}$ & $\begin{array}{l}\text { Salar. } \\
\text { Fontinalis. } \\
\text { Trutta Marina. } \\
\text { Confinis. } \\
\text { Amethystus. } \\
\text { Albus. } \\
\text { Clupeiformis. } \\
\text { Præstabilis. } \\
\text { Lucius. } \\
\text { Estor. } \\
\text { Cephalus. } \\
\text { Carpis. } \\
\text { Versicolor. } \\
\text { Argentatus. } \\
\text { Rutilus. } \\
\text { Pimelodus. }\end{array}$ \\
\hline Anacanthini & Gadidæ & . . . & Gadus & Tom-codus. \\
\hline Acanthopteri & $\begin{array}{l}\text { Percædæ } \\
\text { Scienidæ }\end{array}$ & $\cdot \cdot \cdot \cdot$ & $\begin{array}{l}\text { Perca } \\
\text { Huro } \\
\text { Centrarchus } \\
\text { Labrax } \\
\text { "" } \\
\text { Lucioperca } \\
\text { Corvina } \\
\text { ", }\end{array}$ & $\begin{array}{l}\text { Acuta. } \\
\text { Flavescens. } \\
\text { Nigricans. } \\
\text { Aneus. } \\
\text { Albidus. } \\
\text { Lineatus. } \\
\text { Canadensis. } \\
\text { Oscula. } \\
\text { Richardsonii. }\end{array}$ \\
\hline Ganoidei & Acipenseridæ &.$\quad \cdot$ & Acipenser & Sturio. \\
\hline
\end{tabular}




\section{SCIENTIFIC INDEX}

\section{LARGE GAME, GAME BIRDS, WILDFOWL, AND FRESH-WATER FISH.}

Abramis versicolor, 310 .

Acipenser sturio, 325.

Agialitis semipalmatus, 168.

Aix sponsa, 215.

Alosa præstabilis, 301.

Anas boschus, 196.

" obscura, 202.

Anguilla vulgaris, 250.

Anser albifrons, 190.

" frontalis, 190.

" hyperboreus, 191.

Ardetta exilis, 168.

Aythya Americana, 226.

" valisneria, 221.

Bernicla brenta, 196.

" Canadensis, 191.

Bucephala albeola, 226.

" Americana, 227.

Bonasa umbellus, 155 .

Botaurus lentiginosus, 167.

Camptolæmus Labradorius, 235.

Canis occidentalisvar. griseo-albus, 11.

Castor Canadensis, 33.

Catostomus communis, 310 .
Centrarchus æneus, 322.

Cervus alces, 41.

" Canadensis, 85.

, tarandusvar. caribou, 73 .

" Virginianus, 87.

Charadrius Virginicus, 168.

Chaulelasmus streperus, 206.

Coregonus albus, 290.

" clupeiformis, 294.

Corvina Richardsonii, 325 .

" oscula, 324 .

Cupidonia Cupido, 143.

Cygnus Americanus, 189.

" buccinator, 188.

Cyprinus carpis, 310.

" cephalus, 310 .

Dafila acuta, 207.

Ectopistes migratoria, 121.

Erismatura rubida, 236.

Esox estor, 307.

, lucius, 302.

Felis concolor, 16.

Fuligulinæ, 218. 
Fulix affinis, 220.

" collaris, 221.

" marila, 218.

Gadus tom-codus, 315.

Gallinago Wilsonii, 175.

Harelda glacialis, 231.

Histrionicus torquatus, 229.

Huro nigricans, 317.

Labrax albidus, 322.

, lineatus, 323.

Lagopus albus, 154.

Lepus Americanus, 25.

" campestris, 32.

" sylvaticus, 31 .

Leuciscus argentatus, 310. $" \quad$ rutilus, 310 .

Lophodytes cucullatus, 237.

Lucioperca Canadensis, 324.

Lutra Canadensis, 18.

Lynx Canadensis, 15.

Mareca Americana, 214.

Meleagris gallopavo, 125 .

Melanetta velvetina, 234.

Mergellus albellus, 237.

Mergus Americanus, 238.

, serrator, 238.

Numenius borealis, 180 .

" longirostris, 180.
Nettion Carolinensis, 210.

Oidemia Americana, 232.

" bimaculata, 233.

Ortyx Virginiana, 159.

Pelionetta perspicillata, 233.

Perca acuta, 317.

" flavescens, 317.

Philohela minor, 169.

Procyon lotor, 10.

Querquedula discors, 212.

Rallus Virginianus, 180.

Salmo amethystus, 287.

" confinis, 287.

„ fontinalis, 276.

" salar, 255.

, trutta marina, 288.

Silurus pimelodus, 311 .

Somateria mollissima, 234.

Spatula clypeata, 203.

Tetraonidæ, 140.

Tetrao Canadensis, 140.

Ursus Americanus, 5.

Vulpes fulvus, 13.

"var. argentatus, 14.

"var. decussatus, 14. 


\section{IN DEX.}

Basse, Black, 317.

" Oswego, 323.

, Rock, 322.

" Striped, 323.

" White, 322.

Bear, Black, 5.

Beaver, American, 33.

Bittern, American, 167.

Little, 168.

Bream, 310.

Caribou, 73.

Carp, 310.

Cat-fish, 311.

Chub, 310.

Colin, 159.

Curlew, Common, 180. " Esquimaux, 180.

Dace, 310.

Deer, American, 87.

Duck, Buffel-headed, 226.

„. Canvas-back, 221.

" Dusky, 202.

" Eider, 234.

„ Gadwall, 206.

" Golden Eye, 227.

" Harlequin, 229.

" Labrador, 235.

, Long-tailed, 231.

" Mallard, 196.

" Pintail, 207.

" Red-headed, 226.
Duck, Ring-necked, 221.

" Ruddy, 236.

" Scaup, 218.

"Scaup, American, 220.

, Shoveller, 203.

"Wood, 215.

Eel, Common, 250.

Fisheries, 245.

Fox, Cross, 14.

" Red, 13.

" Silver, 14.

Goose, Brent, 196.

" Canada, 191.

, Dark-fronted, 190.

" White-fronted, 190.

" Snow, 191.

Goosander, 238.

Grouse, Pinnated, 143.

" Ruffed, 155.

" Spotted, 140.

Hare, American, 25.

„ Prairie, 32.

, Wood, 31.

"Herring," Lake, 294.

Lynx, 15.

Masq'allongé, 307.

Merganser, Hooded, 237. 
Merganser, Red-breasted, 238.

Moose, 41.

Otter, Canadian, 18.

Perch, Pike, 324.

,$\quad$ Varieties, 317.

$" \quad$ Yellow, 317.

Pickerel, 324.

Pigeon, Passenger, 121.

Pike, Common, 302.

Plover, Golden, 168. " Ring-necked, 168.

Prairie-hen, 143.

Ptarmigan, 154.

Puma, 16.

Racoon, 10.

Rail, American, 180.

Roach, 310.

Salmon, 255.

Scoter, Common, 232.

" Huron, 233.

" Surf, 233.

" Velvet, 234.
Shad, Canadian, 301.

Sheepshead, Black, 325.

, Common Lake, 324.

Smew, 237.

Snipe, American, $175^{\circ}$.

Sturgeon, 325.

Sucker, 310.

Swan, American, 189.

, Trumpeter, 188.

Teal, American, 210.

"Blue-winged, 212.

Tom-Cod, 315.

Trout, Common, 276.

" Lake, 287.

" Mackinaw, 287.

" Sea, 288.

Turkey, Wild, 125.

Wapiti Deer, 85.

White-fish, 290.

Widgeon, Amerícan, 214.

Wildfowl, 185.

Wolf, Grey, 11.

Woodcock, American, 169. 

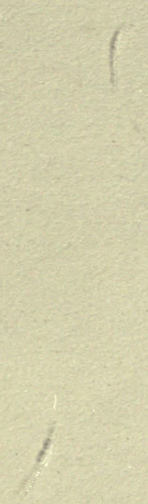

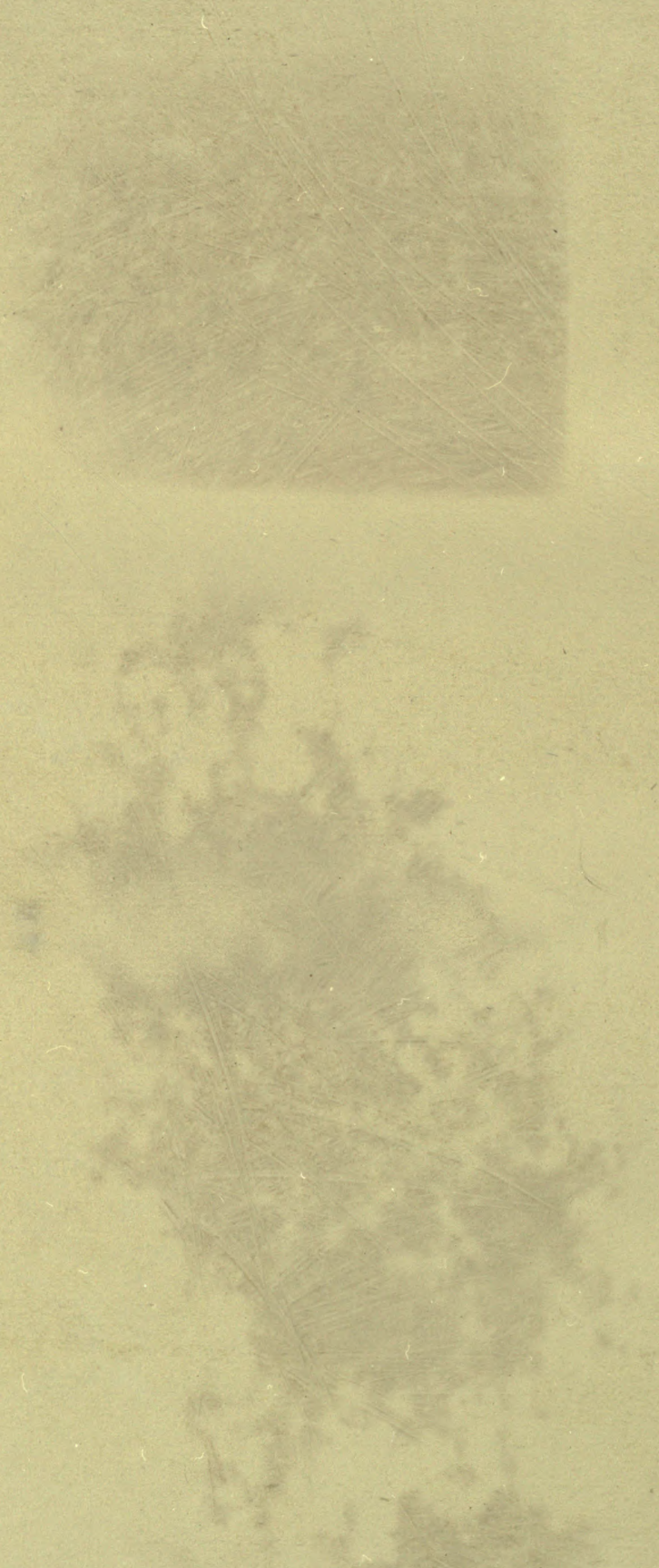


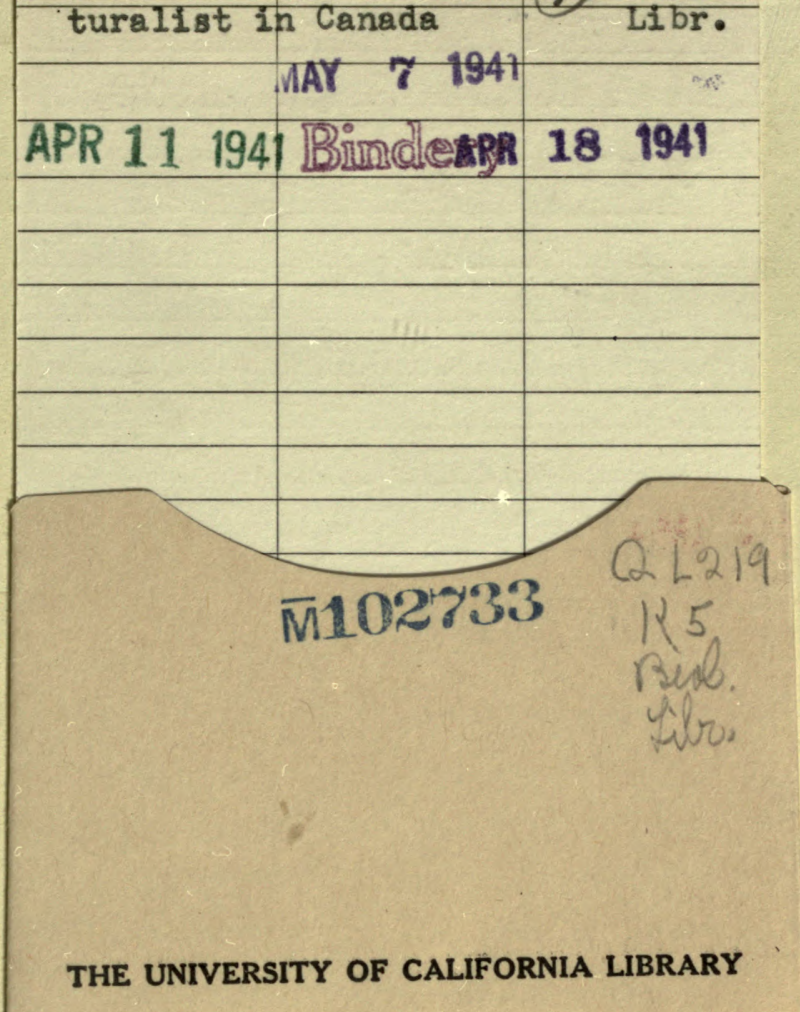




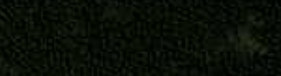

